\title{
THE EFFECT OF PARTIAL STERILISATION OF SOIL ON THE PRODUCTION OF PLANT FOOD.
}

\author{
Part II. The limitation of bacterial nUmbers in Normal \\ SOILS AND ITS CONSEQUENCES. \\ BY EDWARD JOHN RUSSELL AND HENRY \\ BROUGHAM HUTCHINSON

\section{(Rothamsted Experimental Station.)}

IN our earlier communication ${ }^{1}$ we showed that bacteria can no longer be regarded as the only active inhabitants of the soil. We obtained evidence of another group of organisms, detrimental to bacteria, and differing from them by their larger size, slower rate of multiplication under soil conditions, and lower power of resistance to heat and to antiseptics. These are more readily killed than bacteria, and we regarded their suppression as an important factor in determining the increased bacterial activity known to set in after soil has been partially sterilised. Such properties as we were able to ascertain agreed with those of the protozoa, for which we were thus led to look: we found representatives of each of the three groups, ciliates, flagellates and amoebae. We therefore supposed that some of these protozoa constituted the detrimental organisms indicated by our experiments.

Subsequent experiments made by ourselves, by Goodey, Martin, and others, have shown that numerous kinds of protozoa occur in the soil, but they have also revealed a new difficulty, that of ascertaining precisely which kinds are leading their trophic life in the soil and which kinds are present only as cysts. As this problem is not likely to be solved till much more work has been done from the zoological side we decided in the meantime to continue our experiments from our own point of view and to determine the effect on soil fertility of these

\footnotetext{
1 This Joumal, 1909, 3, 111-144.
} 
conflicting groups of organisms. These experiments form the subject of the present paper.

The investigation falls naturally into two parts. In the first instance it is necessary to determine the effect on bacterial numbers of the presence of the detrimental organisms. It follows as a simple deduction from the existence of these organisins that the number of bacteria present per gram of soil at any given time does not depend primarily on the temperature, the water supply or other conditions of the soil, but on the difference in activity of the two groups. Thus a rise of temperature favours not only the bacteria but also the detrimental organisms, and if the latter happen to be favoured more than the former the bacterial numbers will fall. Experiment shows that this deduction is correct. No sort of relationship can be traced between bacterial numbers and temperature, the numbers sometimes rising, sometimes falling, and somẹtimes being unaffected by rise of temperature (Table II). Increases in the amount of soil moisture may or may not increase the numbers of soil bacteria. These erratic effects are not peculiar to our own soil, but are general and have caused much perplexity and not a little controversy among soil bacteriologists in the past $(\$ 5)$. They are entirely explicable on our view that bacterial numbers simply represent the difference in activity of bacteria and the detrimental organisms. Further confirmation is found in the fact that in partially sterilised soils (from which the detrimental organisms are absent) the bacterial numbers increase in a regular manner with rise of temperature and of water content (Figs. 1, 2). Increases in the amount of organic matter in the soil also fail to increase bacterial numbers to a corresponding extent and may indeed, lead to soil "sickness" as shown in previous papers". But when the detrimental organisms are suppressed by partial sterilisation the expected rise in bacterial numbers sets in and the phenomena of "sickness" are not seen.

Similarly any other factor favourable to the growth of living organisms may effect a reduction in bacterial numbers through bringing about a development of the detrimental organisms. Vice versa, causes which in themselves are unfavourable to growth may nevertheless lead to increases in bacterial numbers through suppressing the detrimental organisms.

In the second place we have attempted to trace the connection between bacterial numbers and soil productiveness. Other circumstances

\footnotetext{
1 This :Jounnal, 1912, 5, 27, 86 .
} 


\section{Partial Sterilisation of Soil and Plant Food}

being equal, the greater the numbers of bacteria the more rapid is the production of ammonia and of nitrate in the soil. But we find that an accumulation of either of these substances, and especially of ammonia, tends to stop further accumulation, even though the bacterial numbers increase, so that the relationship between ammonia production and bacterial numbers is no longer seen. No sharp relationship can be looked for in any case because our methods of counting bacteria afford only very rough approximations. There is evidence, however, that the fluctuations shown by the gelatine plate methods correctly reflect the fluctuations of the total numbers of decomposition bacteria; when used for this purpose the data are distinctly valuable. It may happen, however, that the productiveness of the soil is limited by some other factor such as temperature, water supply, insufficiency of calcium carbonate, of phosphates, potassium compounds, etc. and that the additional supply of nitrogenous food is therefore ineffective to raise the crop. Increases in bacterial numbers only increase the productiveness of the soil when the conditions are such that the increased numbers can make more ammonia and nitrate, and when no other limiting factor intervenes to prevent this extra nitrogenous plant food from causing more plant growth.

We have also dealt with some of the objections raised against our main conclusions that organisms exist in the soil detrimental to bacteria, and that the bacterial numbers at a given moment are determined by the mutual interaction of these conflicting groups. It has been asserted that no such organisms exist, and in particular that ciliates and amoebae could not lead a trophic life in the soil. Others have supposed that our results are due to an improvement in the bacterial flora brought about by partial sterilisation, either through the suppression of certain forms detrimental to food-making bacteria or through a stimulus resulting from the treatment and transmitted to the descendants of the surviving organisms. No experimental proof is offered in support of these views and we have been able to adduce direct evidence against them. Our results have also been attributed to the presence of bacteriotoxins in the soil, it being assumed that these toxins are decomposed by the antiseptics (chiefly toluene vapour) that we used. We have also considered the possibility of changes in the colloids and other materials that may be supposed to coat the particles of the soil.

Our experiments show that the detrimental factor has all the attributes of living organisms. Thus it is a positive factor (i.e. it is not a lack of some essential or desirable condition); it is capable of 
growth and of extinction; once extinguished it does not arise again until some of the untreated soil is added. The difficulty of defining life is well known, but we think the sum of the properties points conclusively to a living organism. Further, every deduction we have made from the existence of the two conflicting sets of organisms has been justified by experiment, while each new experimental fact that has come to light is found to fit in readily. Our identification of the detrimental organisms with certain soil protozoa is only provisional and may be modified by subsequent zoological surveys of the soil fauna; for the present, however, we adhere to it because it accords with all the known facts.

Definite evidence could be obtained against the view that the bacterial flora is improved by partial sterilisation. The flora as a whole is certainly more effective in bringing about various decompositions, but this arises from an increase in numbers and not from an increased efficiency of the organisms. As a matter of fact the organisms lose in efficiency, and, when the old flora is put under the same conditions as the new by inoculating it into partially sterilised soil, then it attains numbers much higher than the new and brings about more decomposition ( $(24$, Table $X)$.

We have failed to find bacteriotoxins in our soils which, it should be noted, are fairly rich in calcium carbonate. Further, the deductions made from the bacteriotoxin hypothesis do not all come out right: e.g. the toxins ought to accumulate in partially sterilised soils where there is great bacterial activity, but they do not (\$22). Certain of the observed facts can be explained on the hypothesis, but as new facts are brought out it becomes necessary to attribute new and nore remarkable properties to the toxins in order to account for them.

There is more difficulty in dealing with the changes that might be induced in the soil colloids because it seems possible to attribute to colloids practically all the properties of living organisms. The evidence, however, seems to be against this view as a complete explanation of all the phenomena.

Of course we do not assert that bacteriotoxins do not exist in any soils or that the condition of the soil colloids plays no part in determining the bacterial population, or that partial sterilisation has no other effect on the soil except to destroy the harmful organisms. On the contrary we have shown that heating the soil to $100^{\circ} \mathrm{C}$. or higher temperatures brings about considerable decomposition and considerably 


\section{Partial Sterilisation of Soil and Plant Food}

alters the soil as a medium for the growth of micro-organisms'. Even the milder treatment with antiseptics does not leave the soil wholly unchanged but produces effects some of which are dealt with in a later paper. Some of our results conld be explained on the supposition that heat, toluene, etc. set free some substance essential or favourable to bacteria, the lack of which in the untreated soil was limiting their numbers. But many of our results cannot be explained in this way. The only hypothesis covering all the facts is that in normal soils bacteria are not the only active organisms, but that larger organisms occur detrimental to them, and the bacterial population of the soil at any moment is determined by the mutual interaction of these conflicting groups.

\section{EXPERIMEN'TAL PART.}

\section{The EFFect of the DEtrimental organisms on the BACTERIAL NUMBERS IN THE SOIL.}

$\$ 1$. During the course of our investigations we have frequently had occasion to bring in soils from the field, submit portions to partial sterilisation processes, keep them in bottles under constant conditions of moisture and aeration at the laboratory temperature and make periodical counts of the bacteria by gelatine plate cultures. Some of the results are collected in Table I. The numbers in the untreated soils often vary in rather an erratic manner, rising and falling for no obvious reason; they show much more regularity in the partially sterilised soils, however, and generally rise steadily to a maximum at which they either remain or begin to fall; only rarely do they fluctuate as in the untreated soils.

As the partially sterilised soils had been kept alongside of the untreated soils and were equally moistened and aerated, the difference in behaviour cannot be attributed to any external cause but must be put down to some condition present in the untreated and absent from the partially sterilised soils.

\footnotetext{
1 It seems impossible to convince some soil biologists that the organic matter of the soil suffers decomposition on heating to high temperatures, thereby changing the soil as a medium for the growth of organisms. Again and again we find distinguished investigators steaming soil under pressure and assuming that it has undergone no change. Conclusions drawn from experiments with these steamed soils are applied to ordinary unheated soils, not only without modification, but apparently without seeing the need for any moditication. And yet for the past thirty years chemists have been giving proofs of this decomposition.
} 
$\S 2$. A simple explanation is afforded by the consideration that bacteria are not the only active inhabitants of the soil but are accompanied by larger organisms detrimental to them and keeping them in check. On this view the number of bacteria in the soil at a given moment represents the balance of activity of the two sets of organisms and is therefore not connected in any simple way with the temperature, water supply, etc. These factors can increase the bacterial numbers only if they shift the balance in favour of the bacteria, and whether or not this can happen in a particular case is only discoverable on our present knowledge by actual trial.

TABLE I. Numbers of bacteria in untreated and in partially sterilised soils.

Millions per gram of dry soil.

\begin{tabular}{|c|c|c|c|c|c|}
\hline & $\begin{array}{l}\text { At } \\
\text { stturt }\end{array}$ & $\begin{array}{c}\text { End of } \\
\text { 1st period }\end{array}$ & $\begin{array}{c}\text { Eud of } \\
\text { 2nd period }\end{array}$ & $\begin{array}{l}\text { End of } \\
\text { 3rd period }\end{array}$ & $\begin{array}{l}\text { End of } \\
\text { 4th period }\end{array}$ \\
\hline $\begin{array}{r}\text { Soil } 1 \text {-Untreated soil } \ldots \ldots \ldots . . . \\
\text { Soil treated with } \mathrm{CS}_{2} \ldots\end{array}$ & $\begin{array}{r}27 \\
2\end{array}$ & $\begin{array}{c}16 \text { days } \\
10 \\
17\end{array}$ & $\begin{array}{c}30 \text { days } \\
10 \\
53\end{array}$ & $\begin{array}{c}74 \text { days } \\
45 \\
121\end{array}$ & \\
\hline $\begin{array}{r}\text { Soil } 2 \text {-Untreated soil } \ldots \ldots \ldots . . . \\
\text { Soil heated to } 65^{\circ} \mathrm{C} . \quad \ldots\end{array}$ & $\begin{array}{l}13 \\
13\end{array}$ & $\begin{array}{c}15 \text { days } \\
9 \\
21\end{array}$ & $\begin{array}{c}110 \text { days } \\
4 \\
37\end{array}$ & $\begin{array}{c}170 \text { deys } \\
9 \\
45\end{array}$ & $\begin{array}{c}200 \text { days } \\
12 \\
60\end{array}$ \\
\hline $\begin{array}{r}\text { Soil 3-Untreated soil } \ldots \ldots \ldots \ldots . . . \\
\text { Soil treated with toluene }\end{array}$ & $\begin{array}{r}11 \\
2\end{array}$ & $\begin{array}{l}40 \text { days } \\
16 \\
43\end{array}$ & $\begin{array}{c}100 \text { days } \\
9 \\
41\end{array}$ & $\begin{array}{l}160 \text { days } \\
13 \\
43\end{array}$ & $\begin{array}{c}500 \text { days } \\
6 \\
18\end{array}$ \\
\hline
\end{tabular}

* In all cases it must be understood that $0.5-1 \%$ of antiseptic is added to the soil (except where otherwise stated) and left to act for about 30 hours, and then allowed to volatilise completely. Sterilised water is then added to bring the soil to the correct degree of moistness. Throughout this paper except in Table III the bacterial numbers are stated in millions per gram of dry soil.

Small changes in conditions may therefore raise or lower the numbers to a disproportionately large extent, or, on the other hand, they may be without action. Thus in the untreated soil we expect erratic results. But in the partially sterilised soils we expect and obtain more regular results. The detrimental organisms are now killed and the surviving bacteria are free to multiply and to show the normal behaviour towards changes of temperature, etc.

I'he influence of soil temperature on bacterial numbers.

$\S 3$. In order to test this deduction a series of experiments was started to ascertain the effect of temperature on the numbers of bacteria 


\section{Partial Sterilisation of Soil and Plant Food}

in the soil. A quantity of fresh arable soil was put through a $\$ \mathbf{m m}$. sieve and divided as uniformly as possible into a number of portions which were kept in bottles plugged with sterile cotton wool. Half of the samples then received 1 per cent. of toluene which, after 24 hours, was allowed to evaporate by spreading out the soil on sterilised paper in a closed room for $30-40$ hours. No smell could then be detected. The soil was returned to the bottles and received sufficient sterilised water to bring all the samples up to a uniform moisture content representing $60-70$ per cent. of the saturation value. Some of the bottles were stored in a shed where the temperature was low but variable $\left(5^{\circ}-12^{\circ} \mathrm{C}\right.$., unfortunately we had no thermostat working at $10^{\circ} \mathrm{C}$.) while others were stored in incubators maintained respectively at $20^{\circ}$, $30^{\circ}, 40^{\circ}$ and $50^{\circ} \mathrm{C}$. Samples were periodically taken out for analysis, the bacteriological results of which are given in Table II. Some of the results are plotted in Figs. 1 and 7.

$\S 4$. In the untreated rich soil (No. 2) kept at $20^{\circ}$ the bacterial numbers rose steadily for 20 days and then fell off; at $30^{\circ}$ the numbers fell during the whole time, while at $50^{\circ}$ the fall was rapid and complete. In the untreated poor soil (No. 1), kept at $20^{\circ}$, the numbers fell off from the outset and are consistently below those in the same soil kept at a lower temperature. At $30^{\circ}$ almost the same results were obtained except on one occasion, at $40^{\circ}$ there is a partial drop which becomes complete at $50^{\circ}$. In the richest soil the same general result is obtained, the numbers fell off at $20^{\circ}$ and are always below those in the soil kept at $5^{\circ}-12^{\circ}$. There is some outburst of activity after the soil has been stored for three weeks at $30^{\circ}$, but this does not persist; at $40^{\circ}$ there is a marked falling off. The most remarkable feature, however, is that, with one exception, the numbers are no higher at $20^{\circ}$ or $30^{\circ}$ than at the lower temperature, but on the contrary they are generally lower.

Thus it appears that, in these untreated soils, rise of temperature does not exert the favourable influence on bacterial numbers that might have been expected; any beneficial effect is only temporary. In other words the detrimental organisms become more active than the bacteria as the temperature rises to $20^{\circ}$.

A wholly different set of results, however, is obtained where the soils have been previously exposed to the vapours of toluene. In the soil $R C$ the numbers steadily rise at $20^{\circ}$ and are always much higher than at the lower temperature; the numbers also rise for a time at $30^{\circ}$, but do not get so high as at $20^{\circ}$. In the richest soil very similar 
results are obtained; there is a steady rise at the low temperature and a much quicker rise at $20^{\circ}$ (the temporary drop after 25 days we are unable to explain). At $30^{\circ}$ the rise is even more rapid but is not maintained, while at $40^{\circ}$ the conditions become less favourable still. The poor soil behaves like the others, except that even at $20^{\circ}$ the high numbers cannot be maintained, but fall to 30 millions per gram. All
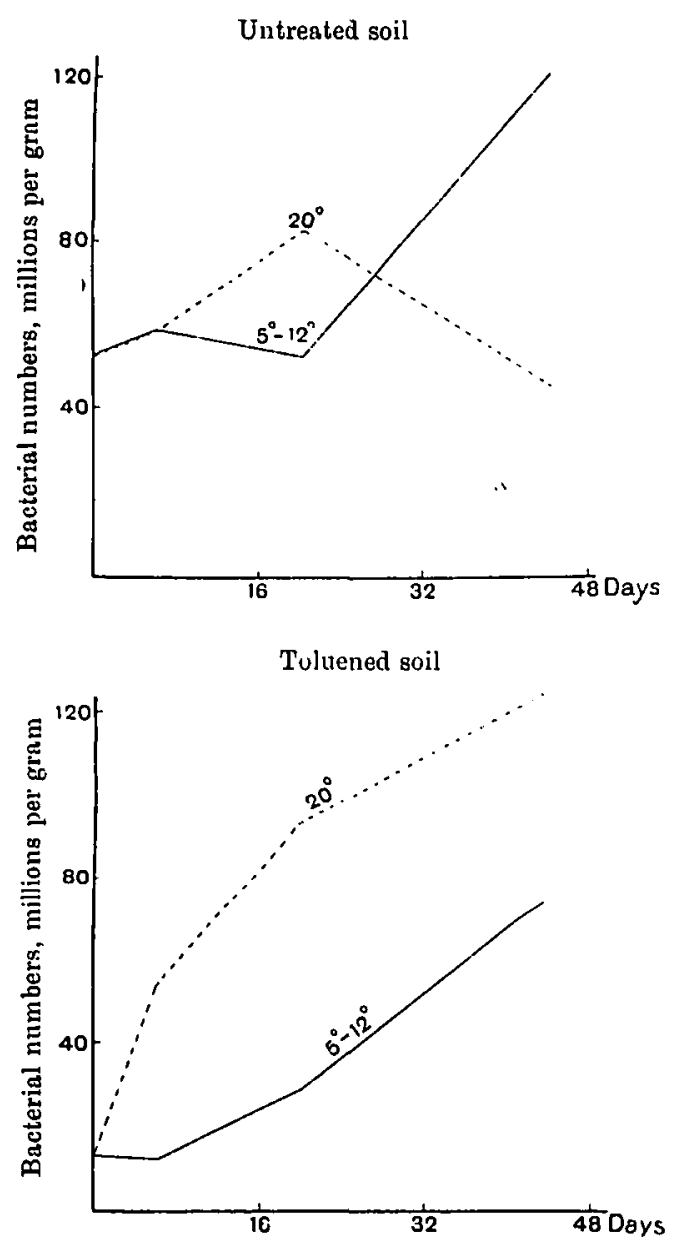

Fig. 1. Effect of varying temperatures of storage on the bacterial numbers in the soil. Soil $R C$ (Table II).

these partially sterilised soils stand out in sharp contrast with the untreated soils in that there is a much more rapid increase in bacterial numbers when the temperature is raised to $20^{\circ}$ than when it is kept 
TABLE II. Effect of temperature on the numbers of bacteria in untreated and in sterilised soils.

Millions of bacteria per gram of dry soil

1. A poor soil contrining $14 \%$ water, $0 \cdot 18 \% \mathrm{~N}, 3 \cdot 16 \%, \mathrm{CaCO}_{3}$ and losing $4.6 \%$ on ignition.

\begin{tabular}{|c|c|c|c|c|c|c|c|c|}
\hline \multirow{2}{*}{$\begin{array}{l}\text { Tempera- } \\
\text { ture, }{ }^{\circ} \mathrm{C} .\end{array}$} & \multirow{2}{*}{$\begin{array}{c}\text { At } \\
\text { start }\end{array}$} & \multicolumn{3}{|c|}{ Untreated soil } & \multirow{2}{*}{$\begin{array}{c}\text { At } \\
\text { start }\end{array}$} & \multicolumn{3}{|c|}{ Soil treated with toluene } \\
\hline & & $\begin{array}{c}\text { After } \\
6 \text { days }\end{array}$ & $\begin{array}{c}\text { After } \\
28 \text { days }\end{array}$ & $\begin{array}{c}\text { After } \\
58 \text { days }\end{array}$ & & $\begin{array}{l}\text { After } \\
6 \text { days }\end{array}$ & $\begin{array}{c}\text { After } \\
28 \text { days }\end{array}$ & $\begin{array}{c}\text { After } \\
58 \text { days }\end{array}$ \\
\hline $5^{\circ}-12^{\circ}$ & 11 & 11 & 9 & 7 & 3 & 8 & 27 & 28 \\
\hline $20^{\circ}$ & 11 & 8 & \pm .5 & 6 & 3 & 50 & 30 & 30 \\
\hline $30^{\circ}$ & 11 & 8 & 9 & 6 & 3 & 43 & 24 & 31 \\
\hline $40^{\circ}$ & 11 & 9 & 2 & $7 \cdot 5$ & 3 & 12 & 4 & fi \\
\hline $50^{\circ}$ & 11 & 4 & 0.7 & 1 & 3 & 2 & 1 & 1 \\
\hline
\end{tabular}

2. A richer soil, $R C$, containing $16 \%$ water, $0.37 \% \mathrm{~N}, 0.57 \% \mathrm{CaCO}_{3}$ and losing $11.05 \%$ on ignition.

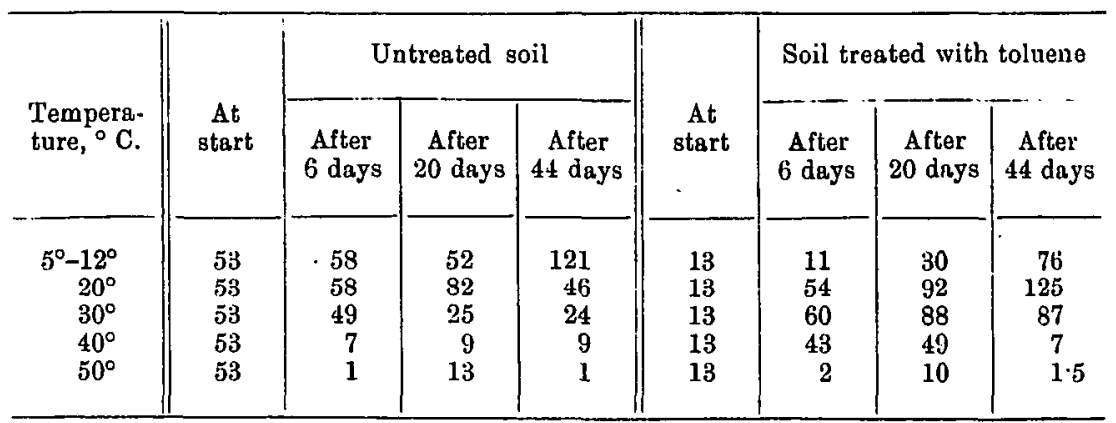

3. A very rich soil, $O x L$, containing $40 \%$ water, $0.63 \% \mathrm{~N}, 1.9 \% \mathrm{CaCO}_{a}$ and losing $17 \%$ on ignition.

\begin{tabular}{|c|c|c|c|c|c|c|c|c|}
\hline \multirow{2}{*}{$\begin{array}{l}\text { Tempera- } \\
\text { ture, }{ }^{\circ} \mathrm{C} \text {. }\end{array}$} & \multirow{2}{*}{$\begin{array}{c}\text { At } \\
\text { start }\end{array}$} & \multicolumn{3}{|c|}{ Untreated soil } & \multirow{2}{*}{$\begin{array}{c}\text { At } \\
\text { sturt }\end{array}$} & \multicolumn{3}{|c|}{ Soil treated with toluene } \\
\hline & & $\begin{array}{c}\text { After } \\
13 \text { days }\end{array}$ & $\begin{array}{c}\text { After } \\
25 \text { days }\end{array}$ & $\begin{array}{c}\text { After } \\
70 \text { days }\end{array}$ & & $\begin{array}{c}\text { After } \\
13 \text { days }\end{array}$ & $\begin{array}{c}\text { After } \\
25 \text { days }\end{array}$ & $\begin{array}{c}\text { After } \\
70 \text { dags }\end{array}$ \\
\hline $\begin{array}{r}5^{\circ}-12^{\circ} \\
20^{\circ} \\
30^{\circ} \\
40^{\circ}\end{array}$ & $\begin{array}{l}65 \\
65 \\
65 \\
65\end{array}$ & $\begin{array}{l}63 \\
41 \\
27 \\
14\end{array}$ & $\begin{array}{r}41 \\
22 \\
50 \\
9\end{array}$ & $\begin{array}{l}32 \\
23 \\
16 \\
\mathbf{3 3}\end{array}$ & $\begin{array}{l}8 \cdot 5 \\
8 \cdot 5 \\
8 \cdot 5 \\
8 \cdot 5\end{array}$ & $\begin{array}{r}73 \\
187 \\
197 \\
148\end{array}$ & $\begin{array}{r}101 \\
128 \\
145 \\
52\end{array}$ & $\begin{array}{r}137 \\
182 \\
51 \\
100\end{array}$ \\
\hline
\end{tabular}

The amounts of nitrogen present as ammonia and nitrate on the various dates are given in Table XVI.

The percentages of nitrogen, calcium carbonate and loss on ignition, are calculnted on the air dried soil in each instance. 
at $5^{\circ}-12^{\circ}$; the bacteria being free to multiply now that the detrimental organisms are killed. It will further be noticed that the organisms counted by the method adopted cannot long survive a temperature of $50^{\circ}$, suffer considerably at $40^{\circ}$, and do not flourish as well at $30^{\circ}$ as at $20^{\circ}$.

$\S 5$. The ineffectiveness of increased temperatures to increase bacterial numbers in ordinary untreated soils is not a peculiarity of our soils. It is seen also in the experiments of Hiltner and Störmer, of Engberding and of Conn, and has been observed also by Löhnis. The bacterial counts made by Hiltner and Störmer ${ }^{1}$ at intervals during a year on field plots show no tendency for bacteria to increase as the temperature rises, the August results being no higher than those obtained in February. Some of their figures are:

Bacteria in millions per gram (Hiltner and Störmer).

\begin{tabular}{|c|c|c|c|}
\hline & \multirow{2}{*}{$\begin{array}{l}\text { Cropped land, } \\
\text { grass and clover }\end{array}$} & \multicolumn{2}{|c|}{ Fallow land, cultivated } \\
\hline . & & No dung & Dung * \\
\hline 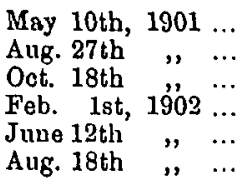 & $\begin{array}{l}8 \cdot 3 \\
3 \cdot 2 \\
6 \cdot 4 \\
6 \cdot 6 \\
8 \cdot 1 \\
4 \cdot 9\end{array}$ & $\begin{array}{l}8 \cdot 0 \\
4 \cdot 2 \\
4 \cdot 0 \\
4 \cdot 1 \\
5 \cdot 7 \\
4 \cdot 1\end{array}$ & $\begin{array}{r}11 \cdot 0 \\
10 \cdot 5 \\
11 \cdot 0 \\
9 \cdot 3 \\
7 \cdot 2 \\
8 \cdot 4\end{array}$ \\
\hline
\end{tabular}

* The dung was applied in July at the rate of 130 to 140 Centner pro Morgen (10 to 11 tons per acre).

Engberding ${ }^{2}$ made a similar but more extensive series of counts of the bacteria in plots of ground at intervals during the year and has published his results in very complete form, giving the mean temperature of the soil during the week when each sample was taken, the moisture content, details of raiufall, etc. Here again no connection whatsoever can be traced between the bacterial numbers and the temperature, in fact it often happens on dates when the moisture contents are similar that the bacterial numbers are higher when the temperature is lower, as in the following examples:

1 L. Hiltner and Störmer, Studien über die Bacterienflora des Ackerbodens, mit besonderer Berücksichtigung ihres Verhaltens nach einer Behandlung mit Schwefelkohlenstoff und nach Brache, drb. Biolog. dbt. Land-u. Forstwirtschaft. Kais. Gesund. 1903, Bd. 3, Heft 5.

2 Diedrich Engberding, Vergleichende Untersuchungen über die Bakterienzahl im Ackerboden in ihnen Abhängigkeit von äusseren Einflüssen, Centr. Bakt. Par. II, 1909, 23, 569-642.

Journ. of Agric. Sci. v 


\begin{tabular}{|c|c|c|c|}
\hline & $\begin{array}{l}\text { Soil temperature } \\
\text { (mean for week) } \\
{ }^{\circ} \mathrm{C} .\end{array}$ & $\begin{array}{l}\text { Per cent. of moisture } \\
\text { st time of sampling }\end{array}$ & $\begin{array}{l}\text { Millions of bacteria } \\
\text { per gram of dry soil }\end{array}$ \\
\hline 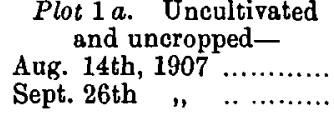 & $\begin{array}{l}16^{\circ} \cdot 6 \\
14^{\circ} \cdot 1\end{array}$ & $\begin{array}{l}16 \cdot 58 \\
16 \cdot 55\end{array}$ & $\begin{array}{l}13 \cdot 09 \\
20 \cdot 85\end{array}$ \\
\hline 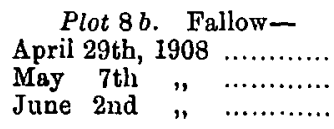 & $\begin{array}{r}9^{\circ .9} \\
13^{\circ \cdot 4} \\
18^{\circ} \cdot 9\end{array}$ & $\begin{array}{l}18 \cdot 69 \\
17 \cdot 31 \\
17 \cdot 87\end{array}$ & $\begin{array}{l}26 \cdot 12 \\
14 \cdot 13 \\
11 \cdot 77\end{array}$ \\
\hline
\end{tabular}

Conn ${ }^{1}$ found that the numbers of bacteria in his plots were high in February, fell in summer and rose again in autumn, and was able to draw up a very neat curve showing the changes of bacterial numbers with the season. He realises that this result implies two conflicting sets of organisms, and suggests tentatively that "there may be two groups of bacteria in the soil, one flourishing in winter, the other in summer. In this case the conflict between these two groups may explain the occurrence of two seasons, one in early fall, the other in winter, when bacteria are particularly numerous." This hypothesis would account for Conn's results but not ours; on the other hand, our hypothesis accounts not only for our own results but for Conn's as well.

Löhnis ${ }^{2}$ has shown that certain bacterial changes, such as the decomposition of cyanamide and urea, take place more rapidly in the soil in spring than in summer. Thus in May 1907 with a temperature of $9^{\circ}$, and a moisture content of 11.2 per cent., decomposition proceeded more rapidly than in the following August when the tempelature was $15^{\circ} .8$ and the moisture content 15.8 per cent.

\section{The influence of moisture content in bacterial numbers.}

$\S 6$. Samples of soil were put up in baskets of silver wire suspended in covered beakers containing water. One sample was fairly dry, a second was moist and contained a very satisfactory amount of water for bacterial development, while the third sample just dipped into the water and was therefore wet without being waterlogged. A parallel set of three put up in the same way had previously been treated with toluene and then received sufficient water to make the percentages

1 H. J. Conn, Bacteria in Frozen soil, Centr. Bakt. Par. II, 1910, 28, 422-434.

2 Löhnis, F. and Sabaschnikoff, A., Ueber die Zersetzung von Kalkstickstoff und Stickstoffkalk, Centr. Bakt. Par. II, 1908, 20, 322-332. Other cases are quoted in Löhnis, Handbuch der Landw. Bakterologie, 1910, p. 596. 
equal to those in the untreated set; the water added contained an extract of the untreated soil carrying bacteria in order to make the bacterial thora as nearly as possible comparable in the two cases. The soils were all kept in the incubator at $25^{\circ} \mathrm{C}$. Counts of the bacteria were made periodically by the gelatine plate method; the results are set out in Table III, and plotted in Fig. 2.

\section{TABLE III. Numbers of bacteria in soils containing varying amounts of water.}

Millions per gram of soil as taken from baskets, and not dried.

(a) Barnfield dunged plot.

\begin{tabular}{|c|c|c|c|c|c|c|}
\hline & & $\begin{array}{c}\text { After } \\
3 \text { days }\end{array}$ & $\begin{array}{c}\text { After } \\
5 \text { days }\end{array}$ & $\begin{array}{l}\text { After } \\
10 \text { days }\end{array}$ & $\begin{array}{c}\text { After } \\
19 \text { days }\end{array}$ & $\begin{array}{l}\text { After } \\
27 \text { days }\end{array}$ \\
\hline $\begin{array}{c}\text { Untreated soil, } \\
\text { ", }\end{array}$ & $\begin{array}{l}\text { dry } \ldots . . . . \\
\text { moist ... } \\
\text { saturated }\end{array}$ & $\begin{array}{r}4 \\
14 \\
26\end{array}$ & $\begin{array}{r}4 \\
24 \\
38\end{array}$ & $\begin{array}{l}13 \\
37 \\
38\end{array}$ & $\begin{array}{r}6 \\
77 \\
52\end{array}$ & $\begin{array}{l}10 \\
20 \\
40\end{array}$ \\
\hline $\begin{array}{c}\text { Toluened soil, } \\
, .\end{array}$ & $\begin{array}{l}\text { dry } \ldots . . . . \\
\text { moist } \ldots . \\
\text { saturated }\end{array}$ & $\begin{array}{r}3 \\
38 \\
29\end{array}$ & $\begin{array}{r}6 \\
26 \\
45\end{array}$ & $\begin{array}{l}10 \\
48 \\
77\end{array}$ & $\begin{array}{l}17 \\
71 \\
58\end{array}$ & $\begin{array}{r}9 \\
\mathbf{3 3} \\
33\end{array}$ \\
\hline
\end{tabular}

(b) Little Hoosfield.

\begin{tabular}{|c|c|c|c|c|c|c|c|c|}
\hline & & $\begin{array}{c}\text { At } \\
\text { start }\end{array}$ & $\begin{array}{l}\text { After } \\
4 \text { days }\end{array}$ & $\begin{array}{c}\text { After } \\
8 \text { days }\end{array}$ & $\begin{array}{c}\text { After } \\
15 \text { days }\end{array}$ & $\begin{array}{c}\text { Aiter } \\
21 \text { days }\end{array}$ & $\begin{array}{c}\text { After } \\
29 \text { days }\end{array}$ & $\begin{array}{c}\text { Moisture } \\
\text { present }\end{array}$ \\
\hline $\begin{array}{c}\text { Untreated soil, } \\
\text { "" }\end{array}$ & $\begin{array}{l}\text { dry ...... } \\
\text { moist ... } \\
\text { saturated }\end{array}$ & $\frac{8}{-}$ & $\begin{array}{r}8 \\
14 \\
8\end{array}$ & $\begin{array}{r}7 \\
7 \\
10\end{array}$ & $\begin{array}{r}8 \\
10 \\
9\end{array}$ & $\begin{array}{r}9 \\
15 \\
16\end{array}$ & $\begin{array}{r}8 \\
10 \\
5\end{array}$ & $\begin{array}{r}8 \cdot 8 \\
13 \cdot 9 \\
-\end{array}$ \\
\hline $\begin{array}{c}\text { Toluened soil, } \\
, "\end{array}$ & $\begin{array}{l}\text { dry } \ldots . . . . \\
\text { moist ... } \\
\text { saturated }\end{array}$ & $\frac{5}{-}$ & $\begin{array}{r}15 \\
58 \\
101\end{array}$ & $\begin{array}{l}\overline{47} \\
98\end{array}$ & $\frac{20}{60}$ & $\begin{array}{r}55 \\
90 \\
116\end{array}$ & $\begin{array}{l}37 \\
80 \\
75\end{array}$ & $\begin{array}{r}7 \cdot 4 \\
12 \cdot 0 \\
-\end{array}$ \\
\hline
\end{tabular}

Reference to the curves shows that in the untreated Barnfield soil (the richer of the two) there has been but little multiplication when the moisture content is low, a more rapid rate when more water is present and, for a time, a still more rapid rate when the soil is wet. But this higher rate of multiplication is only maintained for a short time. After the fifth day the increase in numbers is small and the curve bends over, showing unmistakeably the operation of a limiting factor. In the toluened soil there is no evidence of this limiting factor. The curve 


\section{Partial Sterilisation of Soil and Plant Food}

for the wet soil resembles that for the moist soil but shows a greater rate of bacterial multiplication, as one would expect. When the maximum point is reached the falling off in numbers is slower than in the untreated soil.
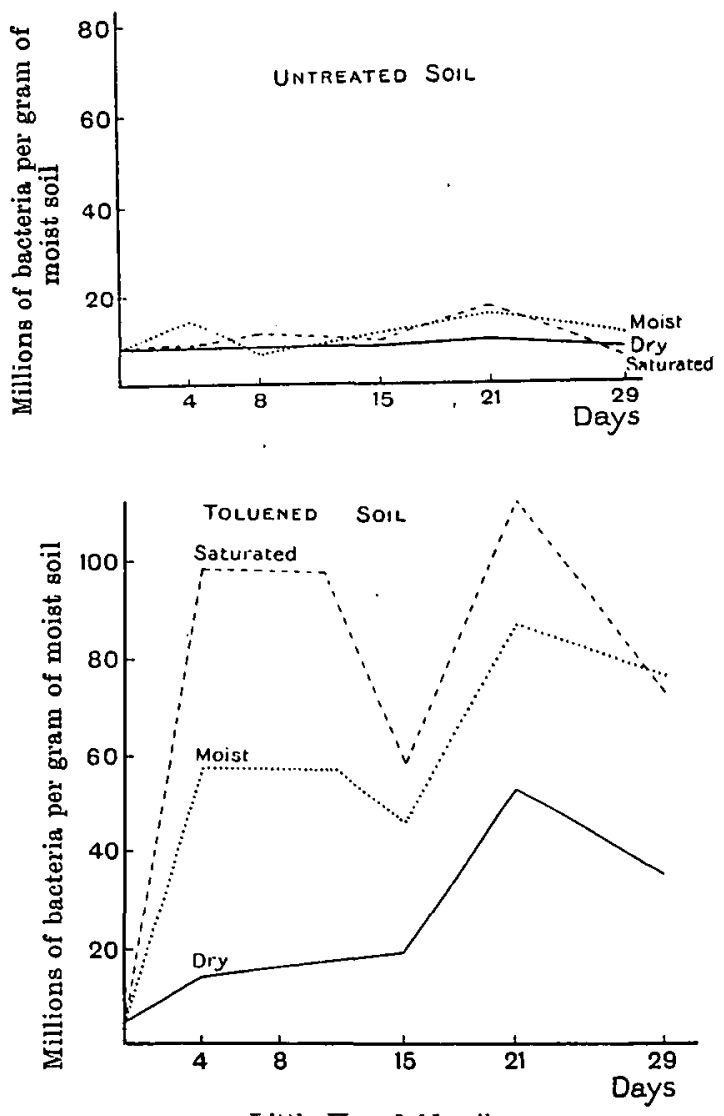

Little Hoosfield soil.

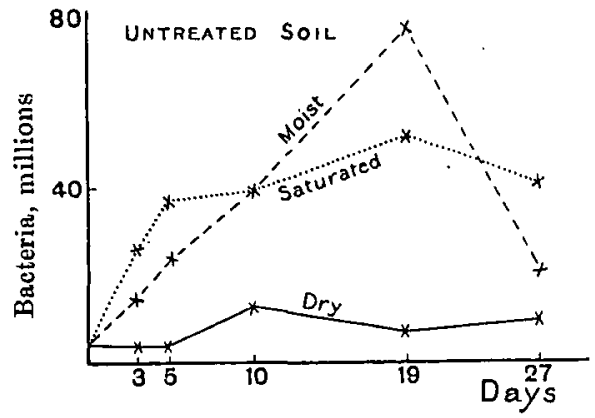




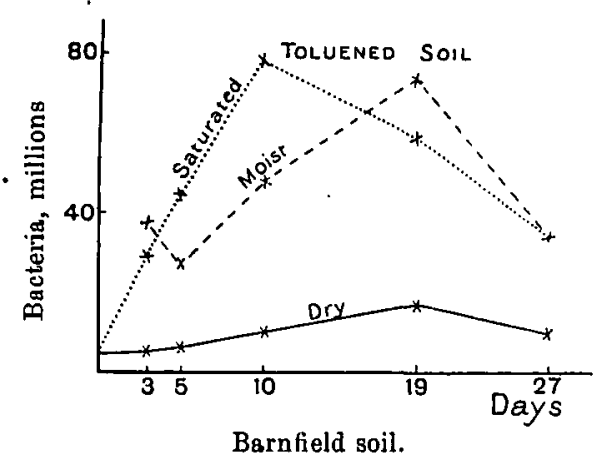

Fig. 2. Effect of variations in moisture content on the bacterial numbers in untreated and partially sterilised soils (Table III).

The addition of moisture is without effect on bacterial multiplication in the untreated Hoosfield soil where a limiting factor is plainly at work, but it leads to regular increases in bacterial numbers in the toluened soil. Apart from two low readings on the fifteenth day, the numbers fall on to a fairly regular curve.

\section{SOME PROPER'TIES OF THE DETRIMENTAL FACTOR.}

\$7. A series of experiments was now undertaken to discover some of the properties of the detrimental organisms with a view to facilitate identification. We decided, however, to work on a more general plan than was strictly necessary for this purpose, and to proceed as if we knew only the existence of a factor detrimental to bacteria but knew nothing as to its nature. We were thus enabled at once to ascertain some of its properties, to obtain still further evidence of its biological nature, and to answer some of the objections that have been raised to our previous work.

Reverting to $\$ 3$ and 4 and to Table II dealing with the effect of soil temperature on bacterial numbers: these results show that the factor is something positive and definite occurring in the untreated soil and not a negative factor such as lack of nutrient or other condition essential or desirable for growth. For it is difficult to see how a negative factor could cause a $d r o p$ in the rate of multiplication at $20^{\circ}$; it would be more likely to set a limit so that the rate would be the same as at the lower temperature."

The moisture results of $\$ 6$, Fig. 2, Barnfield soil, also show the existence in the untreated soil of a positive hindrance to bacterial 


\section{6}

Partial Sterilisation of Soil and Plant Food

growth. The falling off in numbers in the moist soil once the maximum is reached may be attributed to lack of food. But the failure to reach the maximum in the wet untreated soil can only be attributed to the presence of an active detrimental factor; for in the equally wet toluened soil the maximum is speedily attained.

The effect of the toluene is therefore not due to any foodstuff or stimulant, etc. that it may liberate, but to the extinction of something that was actually hindering bacterial development. (See also § 28.)

The experiments fall into three groups dealing respectively with:

1. The determination of the processes by which the detrimental factor can be put out of action, its extinction being indicated by the subsequent rise in bacterial numbers.

2. The biological nature of the factor.

3. Its non-bacterial nature.

\section{METHODS OF EXTINCTION.}

\$ 8. (a) Temperature. The detrimental factor has a fairly sharp extinction point between $55^{\circ}$ and $60^{\circ}$ but it is also put out of action at lower temperatures if the heating is prolonged. Table IV gives the results of bacterial counts made in soils that had been heated for specified times at given temperatures and then stored under favourable conditions of moisture, aeration, etc. It will be observed that a temperature of $56^{\circ}$ is sufficient in the first soil, $55^{\circ}$ is barely sufficient in the second but $65^{\circ}$ is ample, whilst in the third case a temperature of $50^{\circ}$ maintained for one hour temporarily threw out the factor and the same temperature maintained for ten hours apparently extinguished it.

$\$ 9$. On the other hand we failed to find any definite extinction point at low temperatures; there is, however, considerable difficulty in cooling soil owing to its low conductivity. When the cooling was made really effective by pouring liquid air on to soil contained in a Thermos flask and leaving it there to evaporate $((a)$ in Table V) the detrimental factor was put out of action and after 14 days the bacterial numbers were 60 millions per gram in place of 29 in the untreated soil. But the suppression was only temporary, and after a time the factor reasserts itself so that at the end of 42 days the numbers of bacteria were down even below the level in the untreated soil. On the other hand, when the soil was put into narrow test tubes and immersed in liquid air for half an hour the detrimental factor did not suffer and the bacterial numbers remained the same as in the untreated soil $((b)$ and 
(c) in Table V). Immersion of test tubes of soil in solid carbon dioxide for about 2 hours was sufficient in one case to suppress the detrimental factor temporarily but not in another. More prolonged immersion in ice and salt was also successful in one case but the temperature of melting ice produced no change.

TABLE IV. Effect of heat on the detrimental factor.

\begin{tabular}{|c|c|c|c|c|c|c|c|}
\hline \multirow{2}{*}{$\begin{array}{l}\text { Tempera. } \\
\text { ture of } \\
\text { henting }\end{array}$} & \multirow{2}{*}{$\begin{array}{l}\text { Time of } \\
\text { heating }\end{array}$} & \multicolumn{5}{|c|}{ Millions of bacterin per gram of soil } & \\
\hline & & $\begin{array}{c}\text { At } \\
\text { start }\end{array}$ & $\begin{array}{c}\text { After } \\
7 \\
\text { days }\end{array}$ & $\begin{array}{l}\text { After } \\
21 \\
\text { days }\end{array}$ & $\begin{array}{c}\text { After } \\
68 \\
\text { dnys }\end{array}$ & $\begin{array}{c}\text { After } \\
142 \\
\text { days }\end{array}$ & \\
\hline Unbeated & - & 11 & 10 & 12 & 11 & 4 & \\
\hline $40^{\circ}$ & - & $7 \cdot 5$ & 9 & 10 & $7 \cdot 5$ & 3 & Factor not extinguished \\
\hline \multirow[t]{2}{*}{$56^{\circ}$} & - & 2 & 14 & 16 & 37 & 45 & Factor extinguished \\
\hline & & $\begin{array}{c}\text { At } \\
\text { start }\end{array}$ & $\begin{array}{l}\text { After } \\
15 \\
\text { days }\end{array}$ & $\begin{array}{l}\text { After } \\
120 \\
\text { dinys }\end{array}$ & $\begin{array}{l}\text { After } \\
180 \\
\text { days }\end{array}$ & $\begin{array}{l}\text { After } \\
210 \\
\text { days }\end{array}$ & \multirow{5}{*}{$\begin{array}{l}\text { Factor not extinguisbed } \\
? \\
\text { Factor extinguished }\end{array}$} \\
\hline $45^{\circ}$ & - & 13 & 9 & 4 & 9 & 12 & \\
\hline $52^{\circ}$ & - & 15 & 11 & 9 & 13 & 23 & \\
\hline $55^{\circ}$ & - & 5 & 5 & 3 & 13 & 73 & \\
\hline \multirow[t]{2}{*}{$65^{\circ}$} & - & 13 & 21 & 37 & 45 & 60 & \\
\hline & & $\begin{array}{c}\text { At } \\
\text { start }\end{array}$ & $\begin{array}{l}\text { After } \\
13 \\
\text { days }\end{array}$ & $\begin{array}{l}\text { After } \\
\overline{53} \\
\text { duss }\end{array}$ & $\begin{array}{l}\text { After } \\
105 \\
\text { days }\end{array}$ & $\begin{array}{l}\text { After } \\
245 \\
\text { days }\end{array}$ & \multirow{4}{*}{$\begin{array}{l}\text { Factor suppressed but appa- } \\
\text { rently not extinguished } \\
\text { Factor temporarily extin- } \\
\text { guished }\end{array}$} \\
\hline Unherted & $\ldots$ & - & 8 & 9 & 13 & 12 & \\
\hline $50^{\circ}$ & 1 hour & - & 26 & 26 & 15 & 16 & \\
\hline $50^{\circ}$ & 12 hours & - & 15 & 16 & 36 & 20 & \\
\hline
\end{tabular}

('The amounts of nitrogen present as ammonia and nitrate on the various dates are given in Table XV.)

$\S 10$. Our conclusion is that when the soil is cooled the detrimental factor is temporarily put out of action, and the extent to which it suffers depends on the effectiveness of the cooling. A long exposure to a moderately low temperature may be more effective than a short exposure to a much lower temperature. The factor is not permanently extinguished but reappears after a time.

\$11. (b) Rapid drying. Soil was exposed in a thin layer in a hot room at $35^{\circ}-38^{\circ}$ for varying intervals and then moistened and stored in 


\section{Partial Sterilisation of Soil and Plant Food}

bottles in the usual way. The results of the bacterial counts are given in Table VI; they show that 10 days' drying throws the factor out of action, but only temporarily, for the bacterial numbers fell again before 120 days had elapsed, indicating that the factor had become active once more. Another lot of soil exposed to 10 days' hot bright sunshine during June, 1911, behaved in a similar manner. There is a distinct resemblance between these effects, and those observed when soil is heated to $50^{\circ}$ for an hour or cooled to a low temperature. In all of these cases the treatment falls somewhat short of what is wanted for complete extinction of the detrimental factor, and the result is a temporary suppression of the factor, followed by a re-establishment which appears to be complete.

TABLE V. Effect of low temperatures on the detrimental factor.

\begin{tabular}{|c|c|c|c|c|c|c|c|}
\hline \multirow{2}{*}{ Cooling agent } & \multicolumn{5}{|c|}{ Millions of bacteria per gram of dry soil } & \multicolumn{2}{|c|}{$\begin{array}{l}\text { Ammonis and } \\
\text { nitrate produced }\end{array}$} \\
\hline & $\begin{array}{l}\text { Approximate } \\
\text { temperature }\end{array}$ & $\begin{array}{l}\text { Length of } \\
\text { exposure }\end{array}$ & At start & $\begin{array}{c}\text { After } \\
14 \text { days }\end{array}$ & $\begin{array}{c}\text { After } \\
42 \text { days }\end{array}$ & $\begin{array}{c}\text { After } \\
14 \text { days }\end{array}$ & $\begin{array}{c}\text { After } \\
42 \text { days }\end{array}$ \\
\hline Liquid air $(a) \ldots$ & $-180^{\circ} \mathrm{C}$ & $\frac{1}{2}-1$ hour & 8 & 60 & 12 & - & - \\
\hline$" \quad(b) \ldots$ & - & , & $-\overline{8.2}$ & 26 & 27 & - & 28 \\
\hline Solid " $\mathrm{CO}_{2}(a) \ldots$ & $-6 \overline{0^{\circ}} \mathrm{C}$ & 2 hours & 7 & $\begin{array}{l}26 \\
43\end{array}$ & $\begin{array}{l}28 \\
18\end{array}$ & $\overline{23}$ & $\begin{array}{l}25 \\
24\end{array}$ \\
\hline Ice and salt $(a)$ & $-18^{\circ} \mathrm{C}$. & 6 ho"nrs & 7 & $\begin{array}{l}26 \\
10\end{array}$ & 13 & 22 & 26 \\
\hline $\begin{array}{cc}1 \text { ce ana sait } & (a) \\
, & (b)\end{array}$ & -180. & o nours & $\gamma$ & $\begin{array}{l}10 \\
37\end{array}$ & $\begin{array}{l}35 \\
57\end{array}$ & $\begin{array}{l}20 \\
22\end{array}$ & $\begin{array}{l}24 \\
24\end{array}$ \\
\hline $\begin{array}{r}\text { Ice }(a) \ldots \ldots \ldots \ldots \\
\quad(b) \ldots \ldots \ldots \ldots\end{array}$ & $\begin{array}{c}0^{\circ} \mathrm{C} . \\
, "\end{array}$ & $\begin{array}{c}8 \text { hours } \\
",\end{array}$ & 9 & $\begin{array}{l}21 \\
24\end{array}$ & $\begin{array}{l}19 \\
23\end{array}$ & $\begin{array}{l}21 \\
20\end{array}$ & $\begin{array}{l}20 \\
23\end{array}$ \\
\hline Untreated (a)... & - & 一 & 11 & 31 & 21 & 20 & 26 \\
\hline$" \quad(b) \ldots$ & - & - & 一 & 27 & 25 & 22 & 26 \\
\hline
\end{tabular}

In all cases the ammonia was by distillation with magnesia in vacuo as described in this Journal, 1910, 3, 233; and the nitrate by the zinc copper couple method (this Journal, $1912,5,32)$. The results are invariably stated as parts per million of dry soil.

* $\mathrm{N}$ as $\mathrm{NH}_{3}$ varies from 2 to 3 parts, showing that nitrifying organisms were unaffected.

$\S 12$. This result is easy to explain on the view that the factor is biological: the treatment kills many of the detrimental organisms but not all, and the survivors subsequently multiply to their original density; in the meantime, however, the bacteria have a tolerably clear field for development. The result is difficult to explain on any toxin hypothesis unless one can assume that a toxin which is incompletely decomposed has the power of reproducing itself after a time; other hypotheses appear to present similar difficulties (e.g. see $§ 30$, p. 184). 
TABLE VI. Effect of rapid drying on the detrimental factor.

\begin{tabular}{|c|c|c|c|c|c|c|}
\hline \multirow[b]{2}{*}{$\begin{array}{l}\text { Method of } \\
\text { drying }\end{array}$} & \multicolumn{5}{|c|}{ Millions of bacteria per gram of soil } & \\
\hline & $\begin{array}{l}\text { At } \\
\text { start }\end{array}$ & $\begin{array}{l}\text { After } \\
30 \\
\text { days }\end{array}$ & $\begin{array}{l}\text { After } \\
70 \\
\text { days }\end{array}$ & $\begin{array}{l}\text { After } \\
120 \\
\text { days }\end{array}$ & $\begin{array}{l}\text { After } \\
210 \\
\text { days }\end{array}$ & \\
\hline \multirow[t]{2}{*}{$\begin{array}{l}\text { Arable soil } \\
\text { Untreated ....... } \\
24 \text { hrs at } 35^{\circ}-38^{\circ} \\
5 \text { days } " 1 \\
10 \text { days } " . \\
10 \text { days sunshine }\end{array}$} & $\begin{array}{r}11 \\
5 \\
\frac{4}{2}\end{array}$ & $\begin{array}{r}5 \\
7 \\
9 \\
12 \\
18\end{array}$ & $\begin{array}{l}(18) \\
18 \\
17 \\
25 \\
22\end{array}$ & $\begin{array}{r}11 \\
11 \\
9 \\
13 \\
7\end{array}$ & $\begin{array}{r}\overline{7} \\
9 \\
10 \\
11\end{array}$ & \multirow[t]{3}{*}{$\begin{array}{l}\text { Factor not extinguished } \\
\text { Factor temporarily suppressed } \\
\text {,", , }\end{array}$} \\
\hline & $\begin{array}{c}\text { At } \\
\text { start }\end{array}$ & $\begin{array}{l}\text { After } \\
26 \\
\text { days }\end{array}$ & $\begin{array}{c}\text { After } \\
42 \\
\text { days }\end{array}$ & & & \\
\hline $\begin{array}{l}\text { Richer soil, } R C . \\
\text { Untreated .......... } \\
10 \text { days at } 35^{\circ}-38^{\circ}\end{array}$ & $\begin{array}{r}27 \\
7\end{array}$ & $\begin{array}{l}28 \\
37\end{array}$ & $\begin{array}{l}39 . \\
59\end{array}$ & & & \\
\hline
\end{tabular}

\begin{tabular}{|c|c|c|c|c|c|c|c|c|c|c|}
\hline & \multicolumn{5}{|c|}{$\mathrm{N}$ as $\mathrm{NH}_{3}$, parts per million } & \multicolumn{5}{|c|}{$\begin{array}{l}\mathrm{N} \text { as } \mathrm{NH}_{3} \text { and nitrate } \\
\text { million }\end{array}$} \\
\hline & $\begin{array}{l}\text { At } \\
\text { start }\end{array}$ & $\begin{array}{l}\text { After } \\
30 \\
\text { days }\end{array}$ & $\begin{array}{l}\text { After } \\
70 \\
\text { days }\end{array}$ & $\begin{array}{l}\text { After } \\
120 \\
\text { days }\end{array}$ & $\begin{array}{l}\text { After } \\
210 \\
\text { days }\end{array}$ & $\underset{\text { start }}{\text { At }}$ & $\begin{array}{l}\text { After } \\
30 \\
\text { dnys }\end{array}$ & $\begin{array}{l}\text { After } \\
70 \\
\text { days }\end{array}$ & $\begin{array}{l}\text { After } \\
120 \\
\text { days }\end{array}$ & $\begin{array}{l}\text { After } \\
210 \\
\text { days }\end{array}$ \\
\hline 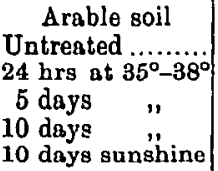 & $\begin{array}{l}\overline{7} \\
9 \\
7 \\
3\end{array}$ & $\begin{array}{l}-\overline{1} \\
1 \\
2 \\
0.5\end{array}$ & $\begin{array}{l}1 \\
1 \\
2 \\
2 \\
1 \cdot 5\end{array}$ & $\begin{array}{l}1 \\
1 \cdot 5 \\
1 \cdot 5 \\
2 \cdot 5 \\
0 \cdot 5\end{array}$ & $\begin{array}{l}-\overline{2} \\
2 \\
1 \cdot 5 \\
2 \cdot 5\end{array}$ & $\begin{array}{l}19 \\
\mathbf{2 5} \\
27 \\
25 \\
\mathbf{2 1}\end{array}$ & $\begin{array}{l}34 \\
31 \\
37 \\
39 \\
\mathbf{3 1}\end{array}$ & $\begin{array}{l}24 \\
37 \\
48 \\
57 \\
42\end{array}$ & $\begin{array}{l}39 \\
44 \\
48 \\
61 \\
44\end{array}$ & $\begin{array}{l}\overline{56} \\
55 \\
81 \\
58\end{array}$ \\
\hline & $\begin{array}{c}\text { At } \\
\text { start }\end{array}$ & $\begin{array}{l}\text { After } \\
26 \\
\text { days }\end{array}$ & $\begin{array}{l}\text { After } \\
42 \\
\text { days }\end{array}$ & & & $\begin{array}{l}\text { At } \\
\text { start }\end{array}$ & $\begin{array}{l}\text { After } \\
26 \\
\text { degs }\end{array}$ & $\begin{array}{l}\text { After } \\
42 \\
\text { days }\end{array}$ & & \\
\hline $\begin{array}{l}\text { Richer soil, } R C . \\
\text { Untreated ......... } \\
10 \text { days at } 35^{\circ}-38^{\circ}\end{array}$ & $\begin{array}{r}5 \\
15\end{array}$ & $\begin{array}{l}2 \\
3\end{array}$ & $\begin{array}{l}3 \\
2\end{array}$ & & & $\begin{array}{l}91 \\
96\end{array}$ & $\begin{array}{l}105 \\
139\end{array}$ & $\begin{array}{l}105 \\
141\end{array}$ & & \\
\hline
\end{tabular}

* In order to save space the uitrute figures are not given separately, but are added to the $\mathrm{NH}_{3}$ figures to yield these totals. The amount of nitrate in any particular case can be readily seen by deducting the corresponding ammonia figure from the total.

\$13. (c) Antiseptics. Organic Liquids. The action of organic antiseptics on the soil is not entirely simple. A small amount of ammonia is immediately produced by some process we have not yet investigated. Subsequently, after the antiseptic is completely removed from the soil, 


\section{0 \\ Partial Sterilisation of Soil and Plant Food}

there sets in a rapid production of ammonia which remains as such because the nitrifying organisms are killed. The bacteria growing on gelatine plates are greatly reduced in numbers by the action of the antiseptics, but they increase to a very considerable extent afterwards.

\$14. Organic liquids that do not possess marked antiseptic properties also cause an immediate liberation of ammonia. This may be (but is not invariably) followed by an increased rate of production of ammonia which is converted into nitrate showing that the nitrifying organisins have survived. There may also be an increase in bacterial numbers. Neither the increased production of ammonia nor the increased rate of multiplication of bacteria (when these phenomena set in) is nearly so marked as in the case of strong antiseptics, and it is not clear whether this is a mild instance of the usual case, or a different type of action altogether. The simplest view is that only the liquid form of these substances is capable of killing the detrimental factor, the vapours being much less potent. As the liquid comes into contact merely with a small part of the soil the partial sterilisation effect is produced only to a restricted extent.

$\S 15$. Table VII shows the effect of hydrocarbons on the soil, approximately one per cent. by weight being used in each case. This was left to act for two days on the soil in tightly closed bottles and was then allowed to evaporate by spreading the soil in a thin layer for some 48 hours. The soil was then moistened and put up in bottles in the usual way. The benzene ring compounds show marked antiseptic properties, killing the nitrifying organisms and the detrimental organisms, and allowing the bacteria subsequently to multiply considerably (the xylenes did not completely volatilise from the soil and appear somewhat to have checked the subsequent bacterial development). Four parts per million of ammonia are produced immediately, and there is a subsequent development of 26 parts in 26 days.

The open chain compounds, however, belong to the second type (\$14). They cause practically the same initial production of ammonia- 5 parts per million-and there is also a subsequent production of ammonia, which, however, amounts to 12 parts instead of 26 in the 26 days. None of the compounds kills the nitrifying organisms. The subsequent effect on the bacterial numbers is variable: pentane causes no increase', hexane a marked one, and heptane a smaller one.

Cyclohexane is intermediate in action between the open chain and the benzene ring compounds.

1 The only case of this action we have observed. See footnote, p. 215. 
TABLE VII. The effect of various organic liquids on bacterial activity in the soil.

100 grams of soil received approximately 1 gram of liquid. Soil from Lucerne ley contained $12 \%$ water, $0.13 \% \mathrm{~N}, 1.8 \% \mathrm{CaCO}_{3}$, and lost $4.9 \%$ on ignition.

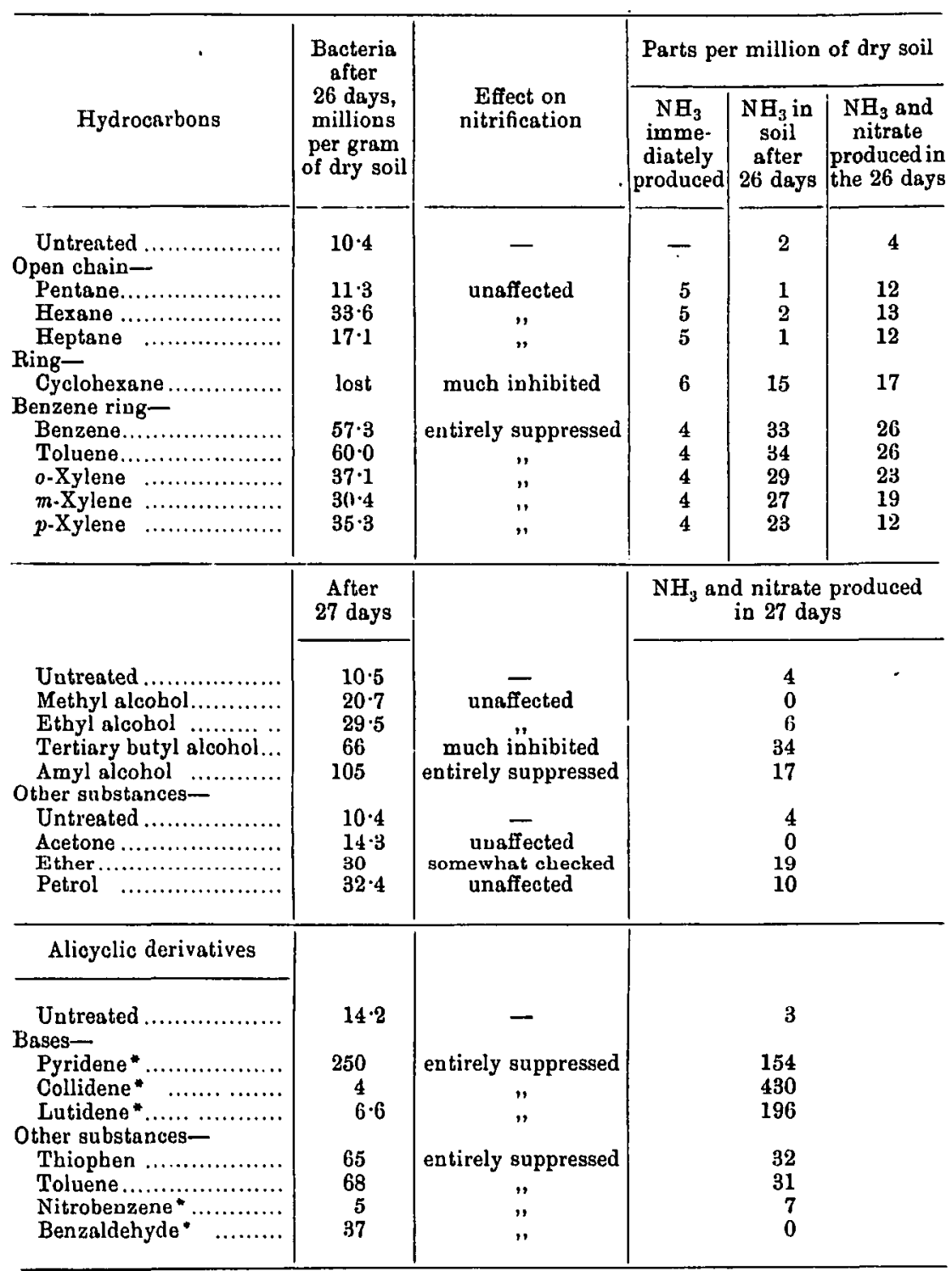

* These substances could not be removed from the soil by volatilisation.

(The rest of the Table is on p. 173.) 


\section{Partial Sterilisation of Soil and Plant Food}

$\S 16$. The alcohols also fall into two groups, methyl and ethyl alcohols being relatively ineffective, while tertiary butyl and amyl alcohols are of the same order of effectiveness as toluene. Further investigation is necessary to decide whether the action is precisely the same as that of toluene, because of the possibility that the traces of alcohol left in the soil may serve as food for the bacteria and so bring about an increase in numbers; it is difficult otherwise to account for the 105 millions of bacteria in the soil treated with amyl alcohol.

Acetone is apparently inert; ether is distinctly active but not nearly so potent as toluene; petrol is less active. In another experiment on another soil both ether and chloroform were practically as effective as toluene.

All these substances, like the hydrocarbons, cause a small immediate liberation of ammonia from the soil.

$\S$ 17. Pyridene behaves in a remarkable manner, causing an enormous rise in bacterial numbers and in the amount of ammonia present in the soil. It was impossible to remove all the pyridene by simple evaporation and a certain anount remained in the soil; the very high amounts of ammonia and bacteria indicate that some of this has been decomposed. 'This result has been obtained on several occasions and always with the purest pyridene obtainable from Kahlbaum; it is the more striking in that pyridene is very stable to ordinary reagents, almost entirely resisting the attack of nitric acid, sulphuric acid, the halogens, etc. Collidene and lutidene also give rise to large amounts of ammonia in the soil. The manurial value of pyridene has been demonstrated in an earlier experiment 1 .

Thiophen behaves exactly like toluene. This result is obtained only when the soil is in so fine a condition that the toluene vapour can penetrate freely. In pot experiments where the soil is lumpy thiophen may prove more effective?

Nitrobenzene and benzaldehyde could not be removed from the soil.

$\S 18$. Inorganic antiseptics. There is considerable difficulty in securing uniform distribution of inorganic antiseptics in the soil because of their non-volatile nature; we have therefore confined ourselves to those that give off poisonous gases. Bleaching powder, calcium sulphide, and hydrogen sulphide in moderate quantities all behave like toluene as shown in Table VII, while sulpbur dioxide (in moderately strong dose), bromine, and flowers of sulphur, all proved too drastic under the

1 E. J. Russell and F. R. Petherbridge, this Journal, 1912, 6, 106.

Loc. cit. p. 110. 
conditions of the experiment; whether in smaller quantities they would behave like calcium sulphide we did not determine.

\section{TABLE VII (cont.). The effect of various inorganic antiseptics on bacterial activity in the soil.}

Arable soil containing $15 \%$ water, $0 \cdot 18 \% \mathrm{~N}, 3 \cdot 16 \% \mathrm{CaCO}_{3}$ and losing $4 \cdot 6 \%$ on ignition. $100 \mathrm{grams}$ of soil received approximately $0.25 \mathrm{grm}$ of antiseptic.

\begin{tabular}{|c|c|c|c|c|}
\hline & \multirow{2}{*}{$\begin{array}{l}\text { Bacteria } \\
\text { after } 30 \text { days, } \\
\text { millions per } \\
\text { gram of dry } \\
\text { soil }\end{array}$} & \multirow[b]{2}{*}{$\begin{array}{c}\text { Effect on } \\
\text { nitrification }\end{array}$} & \multicolumn{2}{|c|}{ Parts per million of soil } \\
\hline & & & $\underset{\text { immediately }}{\mathrm{NH}_{3}}$ & $\begin{array}{c}\mathrm{NH}_{3} \text { and nitrate } \\
\text { produced in } \\
\text { the } 30 \text { days }\end{array}$ \\
\hline $\begin{array}{l}\text { Untreated .......... } \\
\text { Calcium sulphide... } \\
\text { Hydrogen sulphide } \\
\text { Bromine ............ } \\
\text { Flowers of sulphur }\end{array}$ & $\begin{array}{r}8 \cdot 6 \\
42 \cdot 5 \\
64 \cdot 5 \\
4 \cdot 3 \\
4 \cdot 3\end{array}$ & $\begin{array}{c}\text { entirely suppressed } \\
? \\
? \\
\text { suppressed }\end{array}$ & $\begin{array}{l}- \\
1 \\
9 \\
8 \\
0\end{array}$ & $\begin{array}{r}12 \\
18 \\
16 \\
3 \\
0\end{array}$ \\
\hline $\begin{array}{l}\text { Untreated ........... } \\
\text { Sodium sulphite ... } \\
\text { Bleaching powder } \\
\text { Sulphur dioxide ... }\end{array}$ & $\begin{array}{l}11 \cdot 3 \\
10 \cdot 3 \\
32 \\
0\end{array}$ & $\begin{array}{c}\text { unaffected } \\
\text { entirely suppressed } \\
"\end{array}$ & $\begin{array}{l}-1 \\
8 \\
0\end{array}$ & $\begin{array}{r}23 \\
18 \\
34 \\
5\end{array}$ \\
\hline
\end{tabular}

The addition of one per cent. of quick lime was also found to partially sterilise the soil, producing the same kind of effect as toluene and other agents. It caused at first a depression in bacterial numbers, and also in the nitrifying organisms, but later on, when it was converted into carbonate, the usual increase took place both in numbers and in the amount of decomposition. This forms the subject of a later communication.

\$19. All the experiments in which the antiseptic was removed from the soil lead to the same conclusion. Whenever the substance used is sufficiently potent to kill the nitrifying organisms it also puts the detrimental factor out of action, so that after it is removed from the soil, the numbers of bacteria and the rate of production of ammonia both increase to a marked extent. To this rule there is no exception.

To the converse statement there are exceptions: distinct increases in bacterial numbers and rates of ammonia production are sometimes obtained even when the nitrifying organisms are not all killed. The increases are not as marked as before, and the cases can all be explained on the view that the vapours of these substances are much less poisonous to micro-organisms than the liquid states. 


\section{Partial Sterilisation of Soil and Plant Food}

We may conclude that those substances only which are capable of acting as antiseptics in the soil possess the power of suppressing the harmful factor.

$\$ 20$. The mode of action of the toluene. The extinction of the harmful factor by toluene is complete even when only small quantities of toluene are used. There was no consistent difference in the bacterial population of portions of a poor soil that had been treated with 0.25 , $0.5,1,2$ and 4 per cent. respectively of toluene (Table VIII). 0.25 per cent. proved wholly insufficient to "wet" the soil, 4 per cent. on the other hand "wetted" it completely. It thus appears that the action is between the vapour and the soil, not the liquid and the soil.

In the richer soil 0.25 per cent. of toluene proves equally effective with the others for 30 days but not for 74 days. It was clear, however, that the vapour had not penetrated the whole of the soil as some of the nitrifying organisms escaped and set up a brisk nitrification after some 20 or 30 days had elapsed. Even 1 per cent. did not wholly exterminate these organisms but it so depressed them that they did not produce any measurable amount of nitrate till after the 30th day.

0.25 per cent. of carbon disulpbide also proved insufficient to penetrate the soil, as seen by the fact that it only reduces the initial bacterial numbers to 9 instead of 2 millions per gram. It is therefore less effective than 1 per cent., but on the other hand, 1 per cent., which does not thoroughly "wet" the soil, is more effective than 4.4 per cent. which does. The conclusion to be drawn is that action is complete when the vapour has reached all parts of the soil, this point being indicated by the immediate depression of the bacterial numbers to the minimum number represented by the spores, and the suppression of the nitrifying organisms. The extinction of the harmful factor goes alongside with the extinction of the living bacteria and we never get one without the other; the completeness of the process can be accurately gauged by the initial bacterial counts (cf. $0 \cdot 25$ per cent. of $\mathrm{CS}_{2}$ in Table VIII) and by determinations of the amounts of nitrate subsequently formed. This close relationship is precisely what would be expected if the extinction of the harmful factor is a process of killing, i.e. if the harmful factor is a living organism.

$\$ 21$. If, however, we suppose that the harmful factor is some physical or chemical condition which is changed to a beneficial factor by antiseptic vapours we must note (1) that once the soil is penetrated the action is not proportional to the mass of the toluene and is therefore irreversible (this is also demonstrated in the next paragraph in 
TARLE VIII. Effect of varying quantities of antiseptics on the bacterial numbers and rate of ammonia production in soils.

(a) Toluene. Arable soil as before (p. 173, Table VII).

\begin{tabular}{c|c|c|c|}
\hline $\begin{array}{c}\text { Quantity of } \\
\text { antiseptic used } \\
\text { per } 100 \text { of soil }\end{array}$ & \multicolumn{4}{|c}{ Millions of bacteria per gram of dry soil } \\
\cline { 2 - 4 } & At start & After 30 days & After 80 days \\
\hline None & 11 & 8 & 9 \\
0.25 & $2 \cdot 7$ & 47 & 52 \\
0.5 & $2 \cdot 3$ & 35 & 44 \\
1.0 & 2.9 & 36 & 57 \\
2.0 & 2.5 & 36 & 45 \\
4.0 & 2.7 & 35 & 43 \\
\end{tabular}

Ficher soil, $R C$, containing $23 \%$ water, $0.37 \% \mathrm{~N}, 0.57 \% \mathrm{CaCO}_{3}$, and losing $11.05 \%$ on ignition.

\begin{tabular}{|c|c|c|c|c|}
\hline & & After 16 days & After 30 days & After 74 days \\
\hline $\begin{array}{c}\text { None } \\
0.25 \\
1.0 \\
4.0\end{array}$ & $\begin{array}{r}27.5 \\
4.0 \\
3.5 \\
2.5\end{array}$ & $\begin{array}{l}10 \\
29 \\
24 \\
31\end{array}$ & $\begin{array}{l}10 \\
29 \\
26 \\
34\end{array}$ & $\begin{array}{r}45 \\
91 \\
132 \\
114\end{array}$ \\
\hline
\end{tabular}

(b) Carbon disulphide. Richer soil, $R C$.

\begin{tabular}{c|r|r|r|r} 
None & $27 \cdot 5$ & 10 & 10 & 45 \\
0.25 & 9.0 & 27 & 17 & 78 \\
1.0 & 1.6 & 17 & 53 & 121 \\
4.4 & $2 \cdot 3$ & 16 & 32 & 92 \\
\hline
\end{tabular}

(a) Toluene. Arrble soil containing $12 \%$ water.

\begin{tabular}{|c|c|c|c|c|c|c|c|}
\hline \multirow{2}{*}{$\begin{array}{l}\text { Quantity of } \\
\text { untiseptic } \\
\text { used per } \\
100 \text { of soil }\end{array}$} & \multicolumn{3}{|c|}{$\mathrm{N}$ as $\mathrm{NH}_{3}$, parts per million } & \multicolumn{4}{|c|}{$\mathrm{N}$ as $\mathrm{NH}_{3} \&$ nitrate, parts per million } \\
\hline & $\begin{array}{l}\text { At } \\
\text { start }\end{array}$ & $\begin{array}{c}\text { After } \\
30 \text { days }\end{array}$ & $\begin{array}{c}\text { After } \\
80 \text { days }\end{array}$ & $\begin{array}{c}\text { At } \\
\text { start }\end{array}$ & $\begin{array}{c}\text { After } \\
30 \text { days }\end{array}$ & $\begin{array}{c}\text { After } \\
80 \text { days }\end{array}$ & \\
\hline $\begin{array}{c}\text { None } \\
0.25 \\
0.5 \\
1.0 \\
2.0 \\
4.0\end{array}$ & $\begin{array}{r}2 \\
10 \\
7 \\
9 \\
11 \\
9\end{array}$ & $\begin{array}{r}4 \\
26 \\
26 \\
25 \\
25 \\
29\end{array}$ & $\begin{array}{r}2 \\
27 \\
27 \\
29 \\
27 \\
37\end{array}$ & $\begin{array}{l}23 \\
25 \\
24 \\
25 \\
27 \\
23\end{array}$ & $\begin{array}{l}25 \\
42 \\
44 \\
40 \\
42 \\
42\end{array}$ & $\begin{array}{r}30 \\
44 \\
45 \\
47 \\
45 \\
58\end{array}$ & \\
\hline
\end{tabular}

Richer soil, $R C$, containing $23 \%$ water.

\begin{tabular}{|c|c|c|c|c|c|c|c|c|}
\hline & & $\begin{array}{c}\text { After } \\
16 \text { days }\end{array}$ & $\begin{array}{c}\text { After } \\
30 \text { days }\end{array}$ & $\begin{array}{c}\text { After } \\
74 \text { days }\end{array}$ & & $\begin{array}{c}\text { After } \\
16 \text { days }\end{array}$ & $\begin{array}{c}\text { After } \\
30 \text { days }\end{array}$ & $\begin{array}{c}\text { After } \\
74 \text { days }\end{array}$ \\
\hline on & $t$ & $\bar{j}$ & 3 & 3 & 80 & 105 & 102 & 114 \\
\hline 0.2 & - & 35 & 35 & 20 & - & 116 & 124 & 157 \\
\hline 1. & - & 40 & 43 & 38 & - & 114 & 117 & 130 \\
\hline $4 \cdot 0$ & - & 39 & 43 & 67 & - & 123 & 126 & 155 \\
\hline
\end{tabular}

(b) Carbon disulphide. Soil $R C$ containing $23 \%$ water.

\begin{tabular}{c|r|r|r|r|r|r|r|l} 
None & 4 & 5 & 3 & 3 & 80 & 105 & 102 & 114 \\
0.25 & - & 29 & 33 & 62 & - & 105 & 109 & 140 \\
1.0 & - & 37 & 40 & 77 & - & 111 & 114 & 152 \\
$4 \cdot 0$ & - & 39 & 44 & 55 & - & 114 & 118 & 130 \\
\hline
\end{tabular}




\section{Partial Sterilisation of Soil and Plant Food}

another way), (2) that the action is rapid and does not require the addition of energy. It follows for both reasons that the new state is more stable than the old. We shall see that other experiments lead to precisely the opposite conclusion $(\$ 30)$. This hypothesis therefore leads to contradictory results.

The biological nature of the detrimental factor.

This is further demonstrated by the experiments recorded in the following sections.

$\S 22$. Irreversibility of the extinction process. When the factor is put out of action it does not reappear. The bacterial numbers in the toluened and heated soils maintain their high level (Tables I and IV). Further, a soil that has once been treated witb toluene is not altered by re-treatment after a long interval. Table IX shows the results of experiments in which soil was partially sterilised and kept moist and aerated, but free from infection for many months so that active bacterial change might go on; at the end of the period the soil was divided into two parts, one of which was re-treated with toluene while the other was not. The soils were again stored under identical conditions of moisture, aeration, etc. and periodically subjected to analysis.

The immediate effect of the re-treatment is to bring the bacterial numbers down to a comparatively low level as happened after the original treatment. When the toluene is evaporated and the soil moistened the numbers begin to rise, but they only slowly attain their previous level and never much exceed it; the change is thus altogether different from that occurring when an untreated soil is toluened. It will be noticed also that treatment of a previously heated soil has no permanent effect on bacterial numbers, the toluene having done nothing that was not already done by the heat: certain differences have, however, been observed in other soils.

\$23. The factor is therefore not produced in soils kept free from reinfection; once it is removed it does not reappear. It is therefore neitber a bacterial product nor any consequence of bacterial action, for if it were it should accumulate to a recognisable extent in the partially sterilised soils where large numbers of bacteria have been present over long periods.

The new flora compared with the old. The non-bacterial nature of the detrimental factor.

$\S 24$. The bacterial flora of the partially sterilised soil is simpler than that of the untreated soil, but the missing groups can be introduced 
E. J. Russell and H. B. Hutchinson

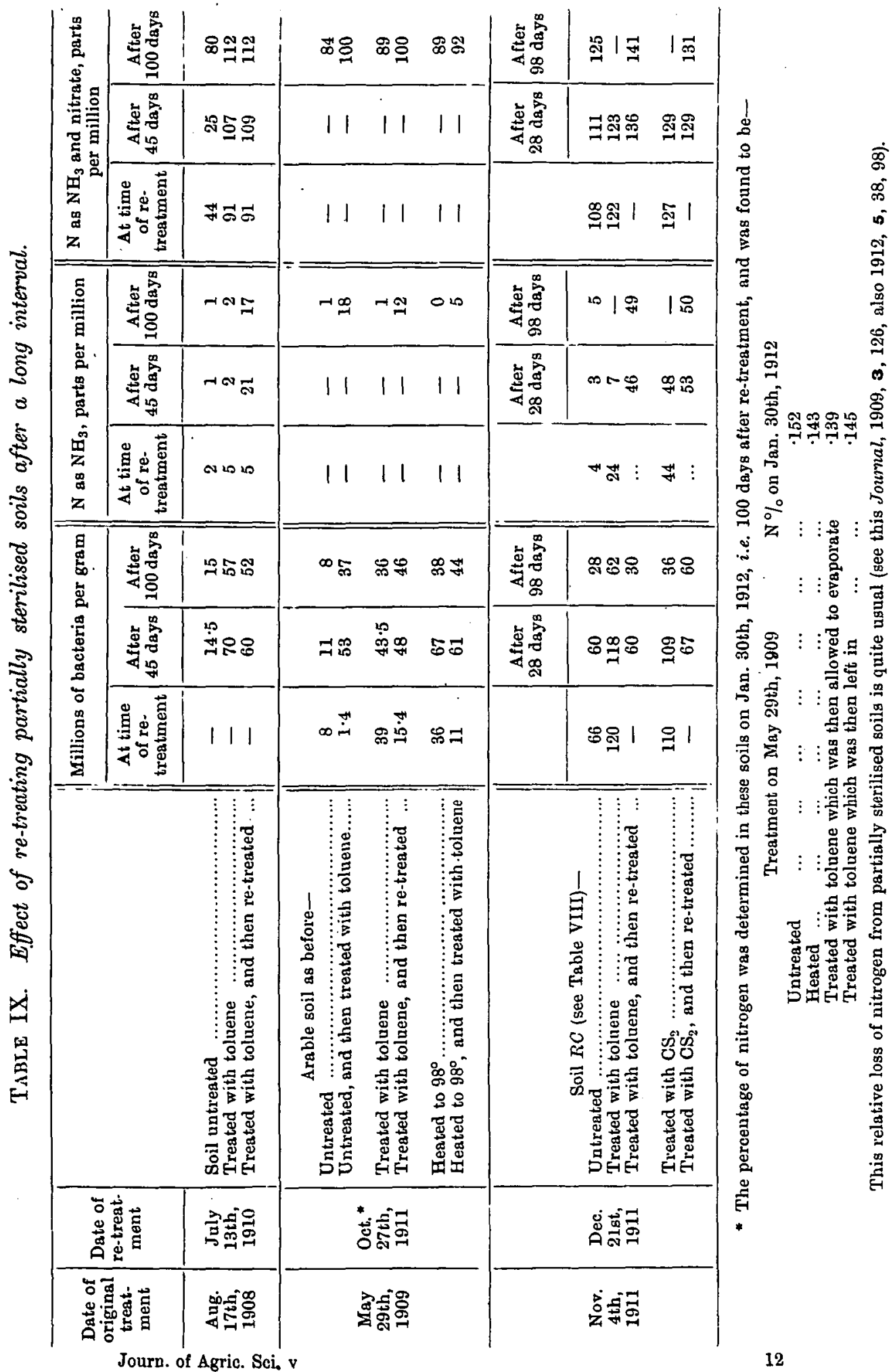




\section{Partial Sterilisation of Soil and Plant Food}

by infecting with a little of the untreated soil, or its water extract. Reference to Table $\mathrm{X}$ shows that the added bacteria develop side by side with those already present in the toluened soil, and there is nothing to indicate that any antagonism exists between the two groups. Now the added organisms include those killed by toluene; the flora in the infected soil therefore approximates qualitatively to that normally present in the untreated soils. But this infected soil flora is always more numerous than that in the toluened soil, and it follows that the flora setting up after partial sterilisation is less able to attain high numbers than the original flora, other conditions being the same. The high bacterial numbers associated with partially sterilised soils are therefore not the result of any improvement in the bacteria themselves.

$\S 25$. This conclusion rules out all hypotheses based on the assumption that partial sterilisation causes the bacteria to multiply inore rapidly either by imparting some stimulus or by removing certain groups of bacteria which somehow prevent the others from multiplying?. It is seen on the contrary that partial sterilisation adversely affects the multiplying power of the bacteria, and the increased numbers follow, not because of the change in type, but in spite of it. The harmful factor is in short associated with something external to the bacteria.

$\S 26$. Two interesting facts are brought out in Table $X$. It is clear that the bacteria on the toluened soil do not occupy the whole ground even when they have attained their maximum numbers because there is still room for other organisms. In Exp. 1, for example, the

1 It is sometimes stated that the new flora has a more favourable effect on the accumulation of plant food in the soil than the old because the denitrifying organisms are killed during partial sterilisation. This statement has several times been disproved but is nevertheless constantly reappearing. We have made numerous experiments on the subject and find that the denitrifying organisms, like the rest, increase after partial sterilisation. As examples, two experiments-may be quoted in which soil was inoculated into Giltay's solution; the following amounts of nitrate were destroyed :

\begin{tabular}{|c|c|c|c|c|c|c|}
\hline & \multicolumn{3}{|c|}{ Experiment 1} & \multicolumn{3}{|c|}{ Experiment 2} \\
\hline & $\begin{array}{c}\text { After } \\
24 \text { hours }\end{array}$ & $\begin{array}{c}\text { After } \\
40 \text { hours }\end{array}$ & $\begin{array}{c}\text { After } \\
64 \text { hours }\end{array}$ & $\begin{array}{c}\text { After } \\
20 \text { hours }\end{array}$ & $\begin{array}{c}\text { After } \\
30 \text { hours }\end{array}$ & $\begin{array}{c}\text { After } \\
40 \text { hours }\end{array}$ \\
\hline 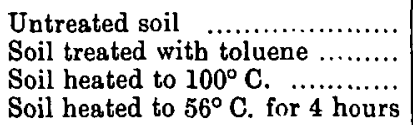 & $\begin{array}{r}3 \cdot 9 \\
8 \cdot 1 \\
0 \\
-\end{array}$ & $\begin{array}{l}13 \cdot 5 \\
13 \cdot 5 \\
10 \cdot 0 \\
--\end{array}$ & $\begin{array}{l}13 \cdot 0 \\
13 \cdot 3 \\
13 \cdot 8 \\
-\end{array}$ & \begin{tabular}{c|}
$2 \cdot 0$ \\
$5 \cdot 6$ \\
$-3 \cdot 1$
\end{tabular} & $\begin{array}{r}4.9 \\
8.6 \\
6.8\end{array}$ & $\begin{array}{r}7 \cdot 2 \\
14 \cdot 3 \\
1 \overline{12 \cdot 6}\end{array}$ \\
\hline
\end{tabular}

It has already been shown that the rate of loss of nitrogen from the soil (presumably as gas) is greater in partially sterilised than in untreated soils; see footnote. p. 177. 
TABLE X. Effect of introducing untreated soil into partially sterilised soils.

Millions of bacteria per gram of dry soil.

\begin{tabular}{|c|c|c|c|c|c|c|c|c|c|}
\hline \multirow{3}{*}{ 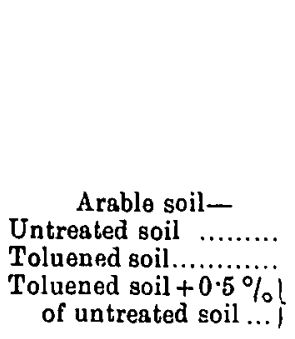 } & \multicolumn{4}{|c|}{ Experiment 1} & \multicolumn{5}{|c|}{ Experiment 2} \\
\hline & $\begin{array}{c}\text { At } \\
\text { start }\end{array}$ & $\begin{array}{c}\text { After } \\
40 \\
\text { days }\end{array}$ & $\begin{array}{c}\text { After } \\
103 \\
\text { days }\end{array}$ & $\begin{array}{c}\text { After } \\
160 \\
\text { days }\end{array}$ & $\begin{array}{c}\text { At } \\
\text { start }\end{array}$ & $\begin{array}{c}\text { After } \\
28 \\
\text { days }\end{array}$ & $\begin{array}{c}\text { After } \\
110 \\
\text { days }\end{array}$ & \begin{tabular}{|c} 
After \\
200 \\
days
\end{tabular} & $\begin{array}{c}\text { After } \\
320 \\
\text { days }\end{array}$ \\
\hline & $\begin{array}{c}11 \\
2 \cdot 2 \\
-\end{array}$ & $\begin{array}{l}16 \\
43 \\
60\end{array}$ & $\begin{array}{r}9 \\
41 \\
71\end{array}$ & $\begin{array}{l}1 \\
4 \\
\vdots \\
4\end{array}$ & $\begin{array}{l}- \\
-\end{array}$ & $\begin{array}{l}14 \\
59 \\
85\end{array}$ & $\begin{array}{r}9 \\
71 \\
54\end{array}$ & $\begin{array}{r}12 \\
81 \\
103\end{array}$ & $\begin{array}{r}8 \\
85 \\
64\end{array}$ \\
\hline & & & & & t start & $\begin{array}{l}\text { Experi } \\
\text { After }\end{array}$ & 45 days & 3 & $\overline{95} \mathrm{deys}$ \\
\hline \multicolumn{5}{|c|}{ 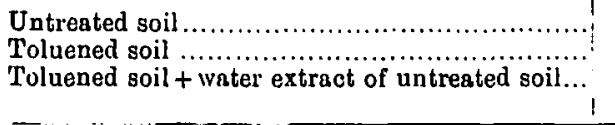 } & $\begin{array}{l}7 \\
2 \cdot 4 \\
2 \cdot 2\end{array}$ & & $\begin{array}{l}11 \\
52 \\
69\end{array}$ & $\begin{array}{l}\vdots \\
\vdots\end{array}$ & $\begin{array}{l}12 \\
41 \\
94\end{array}$ \\
\hline & & \multicolumn{4}{|c|}{$\begin{array}{c}\text { Experiment } 4 \\
\text { Richer soil, } R C\end{array}$} & \multicolumn{4}{|c|}{$\begin{array}{l}\text { Experiment } 5 \\
\text { Very rich soil, } O x L\end{array}$} \\
\hline & & $\underset{\text { start }}{\text { At }}$ & & $\begin{array}{c}\text { After } \\
21 \\
\text { days }\end{array}$ & $\begin{array}{c}\text { After } \\
115 \\
\text { days }\end{array}$ & $\begin{array}{l}\text { At } \\
\text { start }\end{array}$ & & $\begin{array}{l}\text { fter } \\
15 \\
\text { lays }\end{array}$ & $\begin{array}{l}\text { After } \\
115 \\
\text { days }\end{array}$ \\
\hline $\begin{array}{l}\text { Untreated soil } \ldots \ldots \ldots \ldots \\
\text { Tolnened soil } \ldots \ldots \ldots \ldots\end{array}$ & $\begin{array}{l}\text { ln..... } \\
\ldots \ldots \ldots \ldots\end{array}$ & $\begin{array}{l}9 \\
3 \cdot 6\end{array}$ & & $\begin{array}{l}36 \\
73\end{array}$ & $\begin{array}{l}19 \\
32\end{array}$ & 70 & & $\begin{array}{l}82 \\
45\end{array}$ & $\begin{array}{r}45 \\
185\end{array}$ \\
\hline $\begin{array}{r}\text { Toluened soil }+0.5 \% \\
\text { treated soil } \ldots \ldots \ldots \ldots \ldots\end{array}$ & of un. & - & & 122 & 70 & - & & 87 & 222 \\
\hline $\begin{array}{l}\text { Toluened soil + water } \\
\text { of untreated soil...... }\end{array}$ & extract & - & & 131 & 53 & - & & 09 & 250 \\
\hline
\end{tabular}

* In Experiments 4 and 5 the action of toluene was incomplete as nitrification began after the 20th day (see p. 205).

The amounts of nitrogen present as ammonia and nitrate on the various dates are given in Table XIV.

toluened soil supports some 43 million bacteria per gram and no more: but as soon as fresh groups are introduced from the untreated soil another 30 million organisms find room. Some interesting questions are thus raised to which we hope to revert on another occasion. The second fact and one we must now consider a little more fully is that the bacterial numbers fall off in the infected soils even where the numbers in the uninfected soils have remained constant. This is seen 


\section{Partial Sterilisation of Soil and Plant Food}

clearly in Exps. 1 and 2 but it is masked in Exps. 4 and 5 by a fall in numbers on the toluened soil. The experiment necessitates the introduction into our partially sterilised soils of some of the untreated soil and therefore of any of the harmful factor that might be present.

$\S 27$. The introduction of the harmful factor into partially sterilised soil. A detailed series of experiments was arranged to study the effect of introducing untreated soil containing the harmful factor into partially sterilised soils, the method adopted being to mix known proportions of untreated soil with the partially sterilised soil and make periodical bacteriological analyses. Typical results are shown in Table XI and in Fig. 3, from which it appears as before that the immediate effect of the admixture is to increase the bacterial numbers. In Exp. 1 high numbers are maintained where 0.5 per cent. but not where 5 per cent. of untreated soil is added. In Exp. 2 the numbers are all high for the first 21 days but they subsequently fall off considerably where untreated soil is present, in all but one instance becoming much less than numbers

Bacterial numbers, millions per gram.

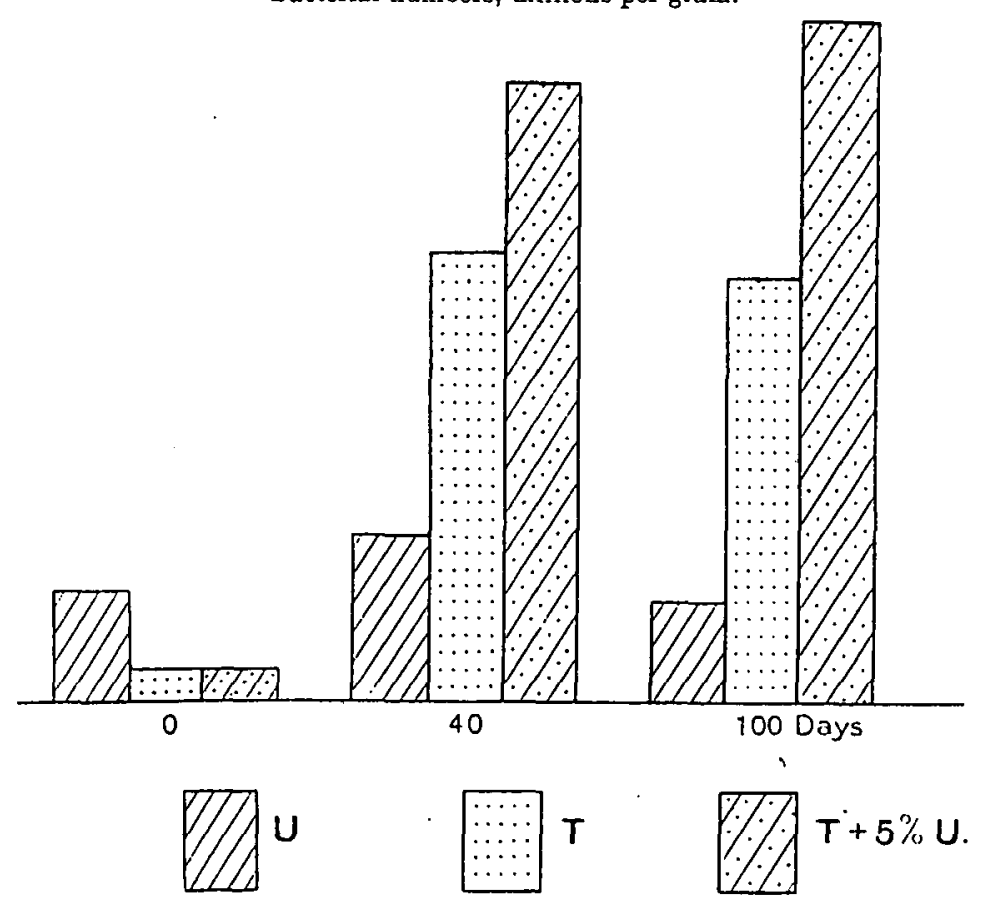

Fig. 3. Columns showing the effect on bacterial numbers of introducing untreated soil into partially sterilised soils. (a) 1st period, where an increase is produced through the activity of the added bacteria. 


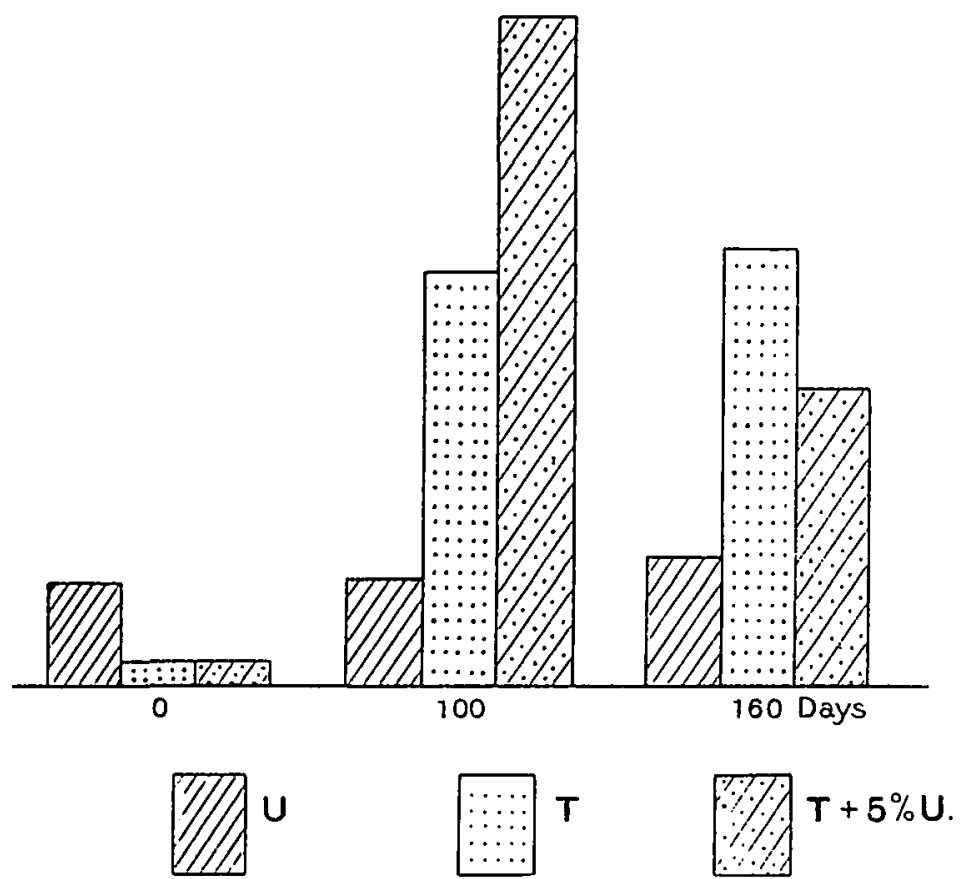

Fig. 3 (continued). (b) 2nd period, where a depression is produced through the slower development of the harmful organisms (Table XI, Exp. 3).

calculated from the proportions of toluened and untreated soil on the assumption that the soils are inert to one another. In all experiments this divergency is noticed after a longer or shorter period; the final counts in Table XI and the calculated figures are as follows:

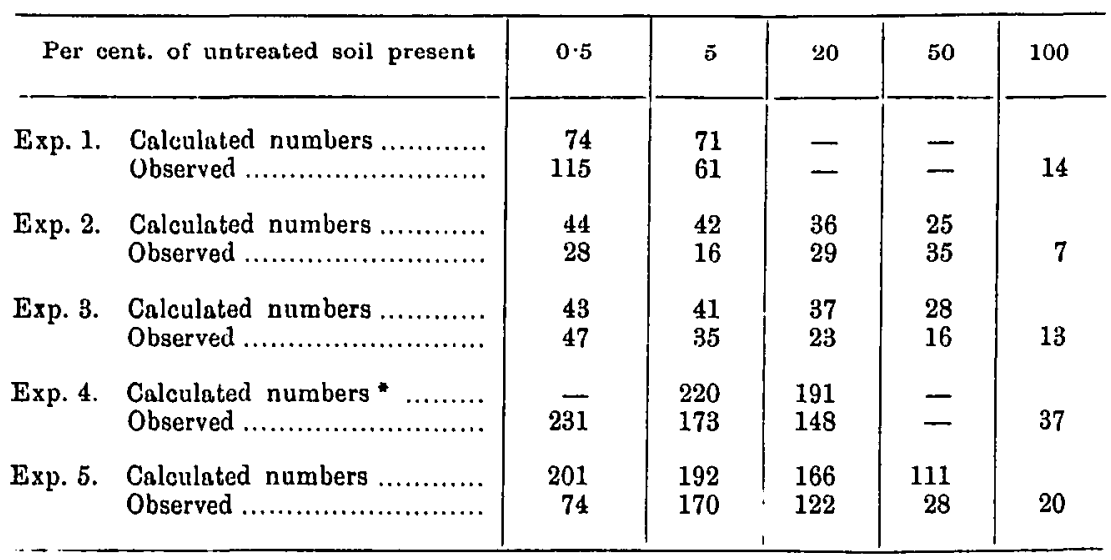

- From toluened soil infected with $0.5 \%$ untreated soil (see note to Exp. 4 on Table XI). 


\section{Partial Sterilisation of Soil and Plant Food}

TABLE XI. Effect on bacterial numbers of introducing untreated soil into partially sterilised soils and vice versa.

Millions of bacteria per gram of dry soil.

Experiment 1. Arrble soil as before.

(a) Untreated soil added to partially sterilised soil.

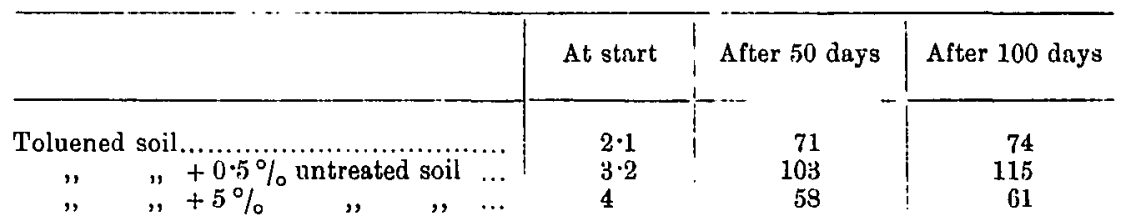

(b) Partially sterilised soil addeil to untreated soil.

Untreated soil

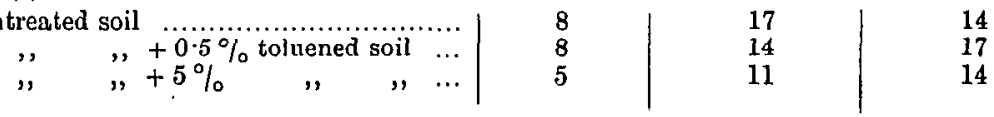

(a) Untreated soil added to partially sterilised soil.

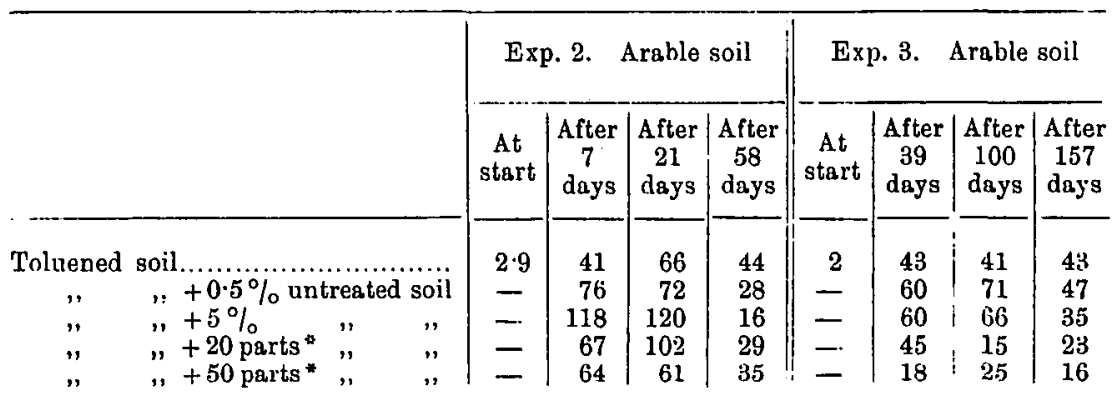

(b) Partially sterilised soil added to untreated soil.

\begin{tabular}{cr|r|r|r} 
Untreated soil............................. & 10 & 9 & 16 \\
$, " \quad,+5 \%$ toluened soil ... & - & 19 & 16
\end{tabular}

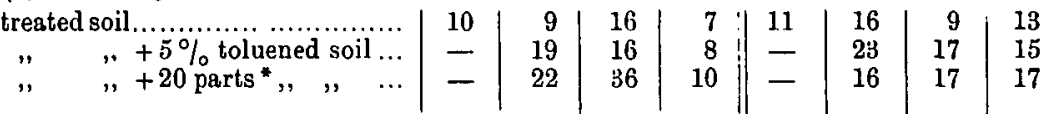

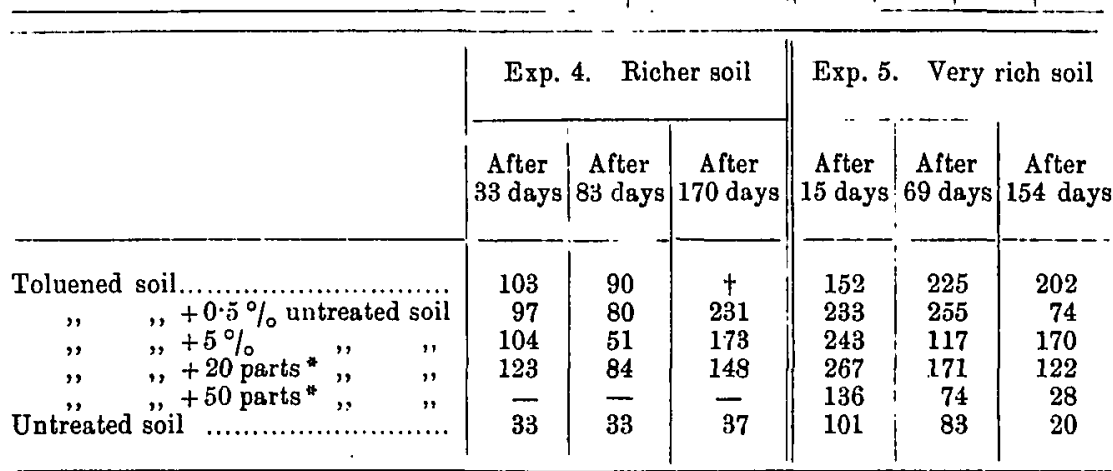

The initial counts in Exps. 4 and 5 and that marked + were lost through liquefaction of the plates.

The composition of the soils and the amounts of nitrogen present as ammonia and nitrate on the various dates are given in Table XIV.

* Parts per 100 of mixture, i.e. 80 of toluened +20 of untreated soil or vice versa and 50 of toluened +50 of untreated soil ; the figures are used in this way throughout the Table. 
$\S 28$. Now we know that these calculated numbers are too low because they take no account of the increase in bacterial numbers that follows introduction of untreated soil into toluened soil, but even so the observed numbers come out still lower. Thus the effect of introducing ๖ per cent. or more untreated soil into partially sterilised soil is first to increase and then after a time to considerably reduce the bacterial numbers, in some cases bringing them down near to the level of the untreated soil.

It might be argued that the high bacterial numbers first induced by additions of untreated to partially sterilised soils exhaust the supply of some essential nutrient set free by the toluene and thus inevitably lead to a reduction in numbers. In this way some of the results of Table XI might be explained (e.g. Exp. 2, and parts of Exps. 3 and 4) without assuming that any detrimental organisms come into play. On the other hand, Exps. 1, 5, and parts of 3 and 4 cannot be thus explained, and the only hypothesis that covers all the results is that the harmful factor has been transmitted to the partially sterilised soils. We thus have further proof that the factor is something positive and is not a negative state such as lack of a stimulant or essential requirement. The second part of the experiment also affords evidence that the untreated soil is not inert but contains a positive detrimental factor: the addition of as much as 20 per cent. of partially sterilised soil to untreated soil fails to increase the bacterial numbers, excepting temporarily and to a small extent. (See also $\S 7$.) Other examples of depression of bacterial numbers in partially sterilised soils by infecting with untreated soils are given in Table XVII (p. 217). The partially sterilised soil B in that Table was mixed with an equal weight of untreated soil and left for $5 \frac{1}{2}$ months. At the end of that time the soils were mixed with hay dust: the bacterial numbers subsequently found were in millions per gram:

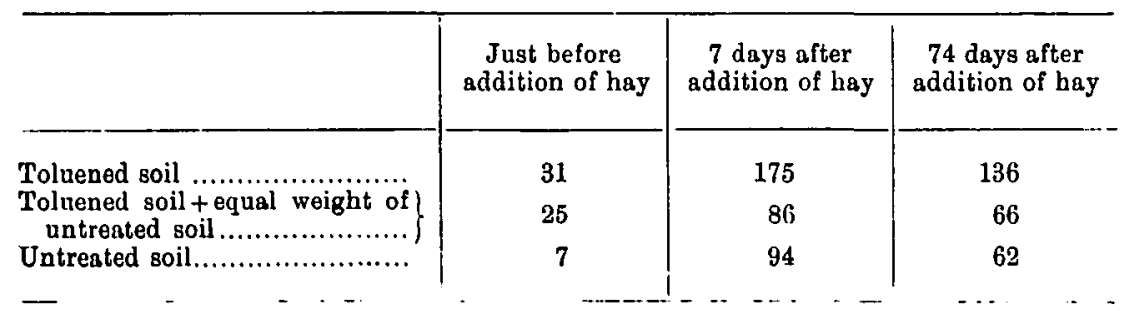

The mixed soil is now indistinguishable from the untreated soil, and the advantage of partial sterilisation has wholly disappeared. 


\section{Partial Sterilisation of Soil and Plant Food}

$\S 29$. The harmful factor is not invariably transmitted to the same extent from the untreated to the partially sterilised soil and in a few cases indeed it is not transmitted at all. The falling off of bacterial numbers from the calculated values follows no sort of rule, being related neither to the numbers of bacteria nor to the amount of added soil. Indeed we get the sarne erratic changes as in the untreated soils in Tables I and II. Only rarely is the transmission so complete as to bring the numbers down to the level of the untreated soil.

$\S 30$. It is possible to explain these results on the supposition that partial sterilisation has effected some chainge in the soil colloids, making them more favourable for bacterial activity. Changes in surface tension and other properties are almost certain to take place and to react on bacterial octivity. But we get into difficulties directly we suppose that this is the sole cause at work. For example: when some of the untreated soil is added the new form reverts to the old and less suitable form; addition of the new form to the old (i.e. of 5 per cent. of toluened soil to untreated soil) is, on the contrary, without effect. The new form is therefore less stable than the old at ordinary temperatures. This result appears to be in entire contradiction with one obtained earlier ( $(21)$. The supposition is also difficult to reconcile with the evidence of the active nature of the factor $(\$ 7)$ and we must therefore discard it as a satisfactory explanation of all the phenomena.

$\S 31$. The bacteriotoxin hypothesis does not account for the results. The depression produced by the introduction of the untreated soil ought to come into operation at once if it were caused by a toxin, and the amount of the depression should be proportional to the amount of added soil. Neither of these results is obtained. Further, as shown in our earlier paper and in Table $\mathrm{X}$, the water extract of an untreated soil has no toxic effect when added to a toluened soil and not infrequently causes an increase in bacterial numbers because it itself carries bacteria. Toxic properties have been attributed to this extract by Greig-Smith ${ }^{1}$ and by Bottomley ${ }^{2}$, but we are unable to obtaiu their results with our soils. Greig-Smith worked with soils in New South Wales which are unfortunately inaccessible to us in a fresh condition, so that we are unable to account for the discrepancys. Bottomley used soils from the Chelsea Physic garden, but in these also we failed to find evidence of a toxin by the methods he adopted.

1 Transactions of the Linnean Society of New South Wales, Nov. 30th 1910.

2 Report of the British Association, 1911.

3 It might arise from a difference in the amount of calcium carbonate present. 


\section{The PROPERTIES OF THE INJURIOUS FACTOR AND ITS} PROBABLE NATURE.

$\S 32$. The properties of the injurious factor ascertained by the preceding experiments are as follows:

(a) It is permanently put out of action by toluene and other antiseptics sufficiently potent to kill nitrifying organisms, and also by heating to $55^{\circ}$. If the soils are kept free from reinfection it does not reappear even though the conditions are made very favourable for bacterial growth.

(b) It is temporarily put out of action by lesser degrees of heat, e.g. $50^{\circ}$ or less, by drying for a sufficient length of time at $35^{\circ}-40^{\circ}$ and by low temperatures. After a time it manifests itself again if the soil is kept under normal conditions of temperature, water supply and aeration.

(c) It can be reintroduced into a soil from which it has been permanently extinguished by the addition of a little untreated soil.

(d) It develops more slowly than bacteria and for some time may show little or no effect ${ }^{1}$; then it causes a marked reduction in the

1 This slow growth of the destructive organisms, which was emphasised in our earlier paper, vitiates some of the criticisms that have been passed on our conclusions. For example, Lipman, Biair, Owen and MoLean (Experiments relating to the possible influence of protozoa on ammonification in the soil, Nevo Jersey Expt. Station Bull. 248, 1912) added pasteurised and untreated soil infusions respectively to mixtures of sterilised soil (hented under a pressure of 1.5 atmospheres of steam) and dried blood. After seven days the pasteurised infusion had induced the formation of no more ammonia than the untreated infusion. They conclude that these results "do not bear aut Russell and Butohinson's contention as to the part played by prutozoa in depressing the activities of soil bacteria."

It does not appear to us that the experiment really bears on the subject. In no case have we observed development of the destructive organisms in anything like so short a time as seven days. Two assumptions are also involved which the facts do not warrant : (1) the amount of ammonia formed is taken as a measure of the number of bacteria (see pp. 191 et seq. on this point), (2) subjecting the soil to the high temperature of steam at $1 \frac{1}{2}$ atmos. is supposed to leave it unchanged. The argument as we understand it reduces itself to this: the destructive organisms made no growth in seven days in a medium A (strongly heated soil), therefore they could make no growth in a longer period in a wholly different medium B (ordinary unheated soil).

In conmon with other soil investigators Fred (Über die Beschleunigung der Lebenstätigkeit höherer und niederer Pfanzen durch kleine Giftmengen, Centr. Bakt. Par. 1912, II, 31, 185-245) assumes that heating the soil has no effect except to kill micro-organisms. He heated soil to $100^{\circ} \mathrm{C}$., added ammonium sulphate and then ether, and continues "nach Russell und Hutchinson's ansicht würde dieses Antiseptikum in amöbenfreiem Boden dann keine günstige Wirkung haben" (we expressly stated in our earlier paper that we made no such claim; see also p. 156 here). No favourable action was observed, as a 
numbers of bacteria and its final effect is out of all proportion to the amount originally introduced. The development is erratic and we have not learnt precisely the conditions under which it best takes place.

(e) It is shown not to be bacterial in nature $(\$ \$ 23,25)$, nor a toxin $(\$ \$ 12,23,31)$, nor any adverse physical or chemical state of any of the soil constituents $(\$ 21,30)$ nor any negative condition such as lack of some essential or desirable factor $(\$ \$ 7,28)$.

soil!.

( $f$ ) It is favoured by conditions favourable to trophic life in the

(g) We see no escape from the conclusion that it is a living organism.

$\S 33$. In our previous paper we identified the injurious organisms with the soil protozoa and our subsequent work supports this view. Examination of a large number of soils shows that protozoa are normal inhabitants of the soil. The total number of species present must be considerable. Goodey ${ }^{2}$ has examined hay infusion cultures and described a number of forms that he picked out, and Martin ${ }^{3}$ has used a plate culture method and got out others. Protozoa commonly and perhaps invariably get into diseased roots wherever mauy bacteria have entered, but so far as we know no one has investigated them; there can be no doubt that they would amply repay study by some competent zoologist. Protozoa have been found in German soils by Hiltner", Störmer ${ }^{5}$ Max Wolff ${ }^{6}$, and R. H. Francé ${ }^{7}$; in the soils of Hawaii by S. S. Peck ${ }^{8}$, and of Porto Rico by Oscar Loew ${ }^{9}$. The evidence seems

matter of fact, excepting only when untreated soils were treated with ether and the author admits that "Diese Beobachtung spricht für Russell und Hutchinson, doch"-he naïvely continues-" doch ist es möglich, und sogar wahrscheinlich, dass die gesteigerte Nitrifika-

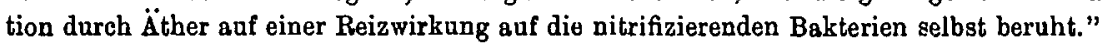

1 This aspect is discussed in this Journal, 1912, 5, 27, 86.

2 A contribution to our knowledge of the protozoa of the soil. Proc. Roy. Soc. 1911, 84 в, 165-180.

A A note on the protozoa from sick soils; ibid. 1912, 85 B, 393-400.

4 Ueber neue Ergebnisse und Probleme auf dem Gebiete der landwirtschaftliohen Bakteriologie, Jahresber. Verein für Angevo. Botanik, 1907, 5, 200.

- Die Wirkung des Schwefelkohlenstoffs auf dem Boden, ibid. p. 123.

6 Der Einfluss der Bewässerung auf die Fauna der Ackerkrume mit besonderer Berücksichtigung der Bodenprotozoen, Mitt. Kaiser Wilhelm Instit. für Landw. , Bromberg, 1909, 1, 382-401; Ueber Bodenprotozoen, Centr. Bakt. Par. 1912, II, 33, 314-320.

7 Studien über edaphische Organismen, Centr. Bakt. Par. 1912, 11, 32, 1-7.

s Some Bio-chemical investigations of Hawaiian Soils, Bull. 34, Expt. Station of the Hawaiian Sugar Planters' Association, 1910.

${ }^{9}$ Annual Report of the Porto Rico Agricultural Expt. Station, 1910. Also R. Emmerich, W. Graf zu Leiningen u. 0. Loew, Über Bodensaüberung, Centr. Bakt. Par. 1912, $\pi, 31,466-477$. Other references are given in Goodey's paper (loc. cit.). 
to be conclusive that any of these organisms occurring in an active state would be inimical to bacteria and would therefore function as the injurious factor.

Rahn' has not only found protozoa in Michigan soils but has formed a minimum estimate of the numbers present per gram, arriving at results of the same order as our own. He further demonstrated that the numbers are considerably reduced on drying.

The great difficulty, and one that none of the seven investigators just mentioned has attempted to deal with, is to determine which forms are active and which remain as cysts under the conditions of the soil. Goodey has devoted much attention to the ciliates developing in hay infusion (Colpoda, etc.) but could find no evidence that they are active in the soil. Martin, on the other hand, considers that some of his organisms-amoebae and amoeboid forms-probably are active. Some of our observations are difficult to explain except on the view that certain protozoa are capable of growth; thus it has happened when small quantities of untreated soil have been added to toluened soil that during the first few days we failed to find either ciliates or amoebae, while later on we found them without difficulty. It is difficult to see why protozoan cysts should remain undeveloped in the soil; bacterial spores certainly show no tendency to accumulate and rarely form more than 20 or 30 per cent. of the total numbers growing on gelatine (Tubles VIII, $\mathrm{X}$ and $\mathrm{XI}$ ). The problem, however, is not likely to be solved until the zoological survey of the soil has proceeded further, and accurate methods devised for counting the protozoa.

$\S 34$. The examination of soil for protozoa is now part of our routine procedure in all experiments on partial sterilisation. Soil is inoculated into a one per cent. hay infusion and left in an incubator at $25^{\circ}$ for 4-5 days, examination being made periodically for protozoa. No identification is attempted, but the organisms are grouped roughly as ciliates, amoebae, and monads; no attempt is made even approximately to estimate their numbers. Partial sterilisation invariably simplifies the fauna considerably, killing the ciliates and amoebae but often leaving certain monads. Whenever the ciliates and amoebae are killed we invariably find that the detrimental factor is extinguished; whenever the detrimental factor is not extinguished the protozoa also are not killed; we have found no exception to these rules.

1 Methode zur Schätzung der Anzahl von Protozoën im Boden. Centr. Bakt. Par. $1913, \mathrm{It}, 36,419-421$. 


\section{Partial Sterilisation of Soil and Plant Food}

The following are typical results obtained for heated soils :

\begin{tabular}{|c|c|c|c|c|}
\hline & $\begin{array}{c}\text { Bacteria after } 68 \text { days. } \\
\text { Millions per gram of } \\
\text { dry soil }\end{array}$ & $\begin{array}{l}\mathrm{NH}_{3} \text { and nitrate formed } \\
\text { after } 68 \text { days. Parts } \\
\text { per million of soil }\end{array}$ & $\begin{array}{c}\text { Detrimental } \\
\text { factor }\end{array}$ & $\begin{array}{l}\text { Protozon } \\
\text { found }\end{array}$ \\
\hline Untreated soil & $11 \cdot 1$ & 18 & present & $\left\{\begin{array}{l}\text { Ciliates } \\
\text { Amoebre } \\
\text { Monads }\end{array}\right.$ \\
\hline $\begin{array}{l}\text { Heated to } 40^{\circ} \\
\text { for } 3 \text { hours }\end{array}$ & $7 \cdot 5$ & $14 \cdot 4$ & present & $\left\{\begin{array}{l}\text { Ciliates } \\
\text { Anroebre } \\
\text { Monads }\end{array}\right.$ \\
\hline $\begin{array}{l}\text { Heated to } 56^{\circ} \\
\text { for } 3 \text { hours }\end{array}$ & $37 \cdot 5$ & $36 \cdot 7$ & killed & \\
\hline
\end{tabular}

Treatment with toluene leads to similar results:

\begin{tabular}{|c|c|c|c|c|}
\hline & $\begin{array}{l}\text { Bacteria after } 30 \text { days. } \\
\text { Millions per gram }\end{array}$ & $\begin{array}{l}\mathrm{NH}_{3} \text { and nitrate formed } \\
\quad \text { after } 30 \text { days }\end{array}$ & $\begin{array}{l}\text { Detrimental } \\
\text { factor }\end{array}$ & $\begin{array}{l}\text { Protozoa } \\
\text { found }\end{array}$ \\
\hline Untreated soil & 8 & $24 \cdot 5$ & present & $\left\{\begin{array}{l}\text { Ciliates } \\
\text { Amoebae } \\
\text { Monsds }\end{array}\right.$ \\
\hline Toluened soil & $47 \cdot 4$ & $41 \cdot 6$ & killed & $\left\{\begin{array}{l}\text { All killed } \\
\text { but certain } \\
\text { Monads }\end{array}\right.$ \\
\hline
\end{tabular}

Quicklime also produces the same effect. So long as small quantities only are added the protozoa are not appreciably affected, the bacterial numbers do not fall in the beginning nor show any subsequent rise. But when a certain larger quantity has been added the partial sterilisation effect is produced, the protozoan fauna is considerably simplified and the bacterial numbers are at first depressed but later on they rise considerably and effect a corresponding production of ammonia (see $\S 18)$.

In Table XII (p. 194) it is shown that a soil stored moist in a closed bottle for 37 years still retained a complex protozoan fauna and a low bacterial population. But after treatment with toluene the protozoa were destroyed (excepting certain Monads) and the bacterial population rose considerably.

But when the soil was heated insufficiently to kill the harmful factor more of the protozoa survive: 


\begin{tabular}{|c|c|c|c|c|c|c|c|}
\hline \multirow{2}{*}{ 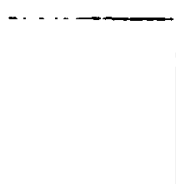 } & \multirow{2}{*}{$\begin{array}{c}\text { Detrimental } \\
\text { factor }\end{array}$} & After & 13 days & After & 53 days & After 2 & 45 days \\
\hline & & $\begin{array}{l}\text { Bacteria } \\
\text { millions }\end{array}$ & Protozoa & $\begin{array}{l}\text { Bacteria } \\
\text { millions }\end{array}$ & Protozoa & $\begin{array}{l}\text { Bacteria } \\
\text { millions }\end{array}$ & Protozoa \\
\hline Untreated ... & Present & 8 & C. A. M.* & 9 & C. A. M. & 12 & C. A. M. \\
\hline $\begin{array}{l}\text { Heated to } 50^{\circ} \\
\text { for } 1 \text { hour... }\end{array}$ & $\begin{array}{l}\text { Present but } \\
\text { suppressed }\end{array}$ & 26 & C. A. M. & 26 & M. & 16 & C. A. M. \\
\hline $\begin{array}{l}\text { Heated to } 50^{\circ} \\
\text { for } 24 \text { hours }\end{array}$ & $\begin{array}{l}\text { Temporarily } \\
\text { extiuguished }\end{array}$ & 15 & none & 16 & $?$ & 20 & A. $\mathbf{M}$. \\
\hline
\end{tabular}

- The contractions C. A. M. stand respectively for Ciliates, Amoebae and Monads.

\begin{tabular}{|c|c|c|c|c|c|c|c|c|}
\hline & \multicolumn{2}{|c|}{ At start } & \multicolumn{2}{|c|}{ After 16 days } & \multicolumn{2}{|c|}{ After 30 days } & \multicolumn{2}{|c|}{ After 74 days } \\
\hline & $\begin{array}{l}\text { Bacteria } \\
\text { millions }\end{array}$ & Protozoa & $\begin{array}{l}\text { Bacteria } \\
\text { millions }\end{array}$ & Protozoa & $\begin{array}{l}\text { Bacteria } \\
\text { millions }\end{array}$ & Protozon & $\begin{array}{l}\text { Bacteria } \\
\text { millions }\end{array}$ & Protozoa \\
\hline Untreated & $27 \cdot 5$ & C. A. M. & 10 & C. A. M. & 10 & C. A. M. & 45 & C. A. M. \\
\hline $0.3 \% \mathrm{CS}_{3}$ & 9 & A. M. & 27 & C. M. & 17 & c. M. & 78 & C. A. M. \\
\hline $1.0 \% \mathrm{CS}_{\mathrm{g}}$ & $1 \cdot 6$ & M.? & 17 & M. & 53 & M. & 121 & A. $\mathbf{M}$. \\
\hline
\end{tabular}

With a still richer soil even more marked results are obtained. In this case carbon disulphide so effectively reduced the protozoa that we could not be sure that any were left, while toluene was much less destructive. The subsequent rise in bacterial numbers was considerably higher after treatment with carbon disulphide than with toluene. 'The fall in numbers on adding 5 per cent. of the untreated soil is also seen to be accompanied by an appearance of a complex protozoan fauna.

\begin{tabular}{|c|c|c|}
\hline & \multicolumn{2}{|c|}{ After 83 days } \\
\hline & $\begin{array}{l}\text { Bacteria } \\
\text { millions }\end{array}$ & Protozoa \\
\hline 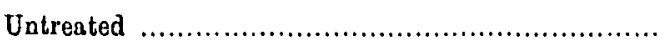 & 90 & C. A. M. \\
\hline 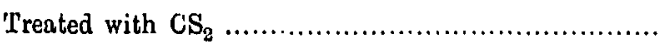 & 326 & None found \\
\hline$" \quad$ " $\quad$ then mixed with $5 \%$ untrented soil & 155 & C. A. M. \\
\hline Treated with toluene & 106 & C. A. M. \\
\hline
\end{tabular}




\section{Partial Sterilisation of Soil and Plant Food}

$\S 35$. In several of the above instances there is evidence of an increasing complexity in the fauna as time goes on, and the simplest explanation is that there has been an actual multiplication of some of the forms which at first were present in numbers too small for us to detect. But we cannot lay too much stress on this point, as the organisms multiply rapidly in hay infusions and we are unable in our final examinations to say whether the soil we started with contained a large or a small number of organisms. This indeed is the weakness of the method. But this very weakness only makes the close connection between the destruction of the, protozoa and the destruction of the harmful factor all the more striking. The survival of protozoa in other experiments unfortunately loses much of its significance because it may only mean that a small number of cysts escaped, but even here it will be noticed that the highest bacterial numbers are never attained when the fauna is complex, i.e. when a relatively large number of protozoa survive. In rich soils toluene often fails to kill all protozoa just as it fails to kill nitrifying organisms and to cure "sickness"; this has been traced to its low solubility and consequent inability to penetrate any but small particles of soil in presence of much moisture or organic matter ${ }^{1}$.

On the other hand, we have failed in our attempts to reduce bacterial numbers in a partially sterilised soil by introducing mass cultures of the ordinary hay infusion protozoa. Our difficulty has been to remove from the cultures the large contaminations of bacteria and bacterial food which cause disturbances directly they get into the soil; we never have a really clean experiment.

$\S 36$. Until a more complete zoological survey of the soil has been made it is not possible to identify the harmful organisms with certainty. We do not even know how they act; whether they devour the bacteria or whether they are present as films round the minute particles of organic matter that would otherwise serve as bacterial food, thus starving the bacterial population down to low limits. The present position in fact, is precisely that in which nitrification stood for many years; the process was known to be biological as far back as 1879 , but the most diligent search among the colonies on the gelatine plate cultures then in vogue failed to bring out the organism. Not till 1891, when a new method was devised, could the organism be isolated with certainty. Our present methods of dealing with soil protozoa are those devised for dealing with pond and stream protozoa, and do not precisely

1 See Russell and Petherbridge, this Journal, 1912, 5, 107. 
reproduce the conditions obtaining in the soil. Therefore we must not at this stage lay too much stress on any relationship that comes out, but may only be accidental, between our detrimental organisms and any of the ciliates, amoebae and monads that these methods reveal. But it seems safe to draw two conclusions: (1) the detrimental organisms possess the properties of protozoa and not of bacteria; (2) the presence or absence of the detrimental organisins is intimately associated with the presence or absence of a complex protozoan fauna. We shall therefore continue to identify the detrimental organisms with the soil protozod without, however, committing ourselves to any particular organism or set of organisms or to any rigid and exclusive definition of the term protozoa.

IV. The relationship between the rate of production of PLANT FOOD IN THE SOIL AND THE INCREASED NUMBERS OF Bacteria brought about by partial sterilisation.

$\S 37$. Partial sterilisation by volatile antiseptics. It was shown in our earlier paper that the increases in bacterial numbers brought about by partial sterilisation with volatile antiseptics lead to corresponding increases in the amount of ammonia produced in the soil. Subsequent experiments have shown that this relationship does not hold universally, but ceases to manifest itself as soon as a certain amount of ammonia and nitrate has accumulated. There is a fairly well-marked limit beyond which the accumulation of ammonia and nitrate will not go, although bacterial multiplication may still continue. This limiting amount varies for different soils and is higher for soils rich in organic matter and therefore capable of retaining a considerable amount of water than for poor soils of lower water-holding capacity; it is also higher in heated than in unheated soils.

$\$ 38$. Determinations of ammonia and nitrates' have been made in all our soils on each occusion when the bacterial numbers were estimated, and the whole of the large mass of data thus obtained can be grouped into two cases:

(1) Soils where the ammonia and nitrates fall well below the limit; here the increase in bacterial numbers following on partial sterilisation causes a corresponding increase in the amount of ammonia and nitrate.

(2) Soils containing much ammonia and nitrate; here the increased numbers of bacteria cause no corresponding increase in the amounts of ammonia and nitrate.

1 See footnotes to Tables V and VI (pp. 168 and 169). 


\section{Partial Sterilisation of Soil and Plant Food}

These cases are illustrated by the curves in Figs. 4 and 5 showing the amounts of ammonia and nitrate, and also the numbers of bacteria present after certain intervals of time. In the diagrams illustrating Case 1 there is a sufficiently close agreement between the curves for bacterial numbers and those for the amounts of ammonia and nitrate to show the intimate relationship between these quantities. Here the highest amount of ammonia present is 4.5 parts per million in the

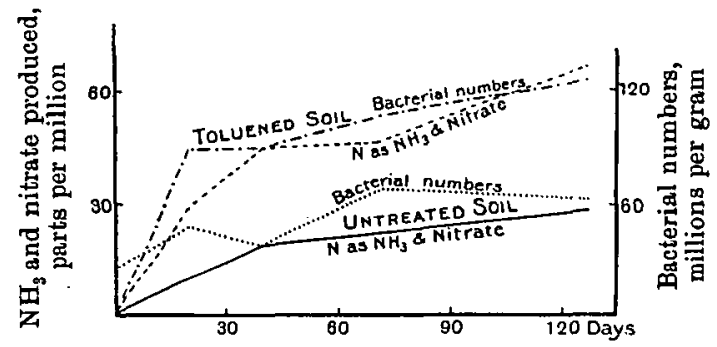

Case 1. Small amounts of ammonia and nitrates initially present (soil $R C$, Table XII (a)). A relationship is indicated between the bacterial numbers and the rate of accumulation of $\mathrm{N}$ as $\mathrm{NH}_{3}$ and nitrate.

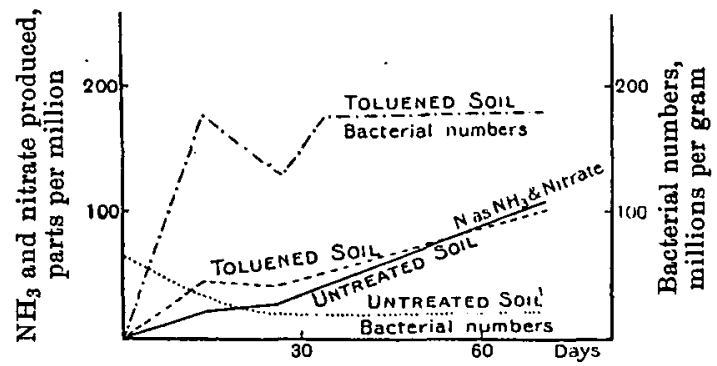

Case 2. Large amounts of ammonia and nitrate initially present (soil $O x L$, Table XII). No such relatiouship can be seen as in Case 1 .

Fig. 4. Ammonis and nitrate produced after certain intervals of time, and also the numbers of bacteria present per gram of soil.

toluened soil, while the ammonia aud nitrate finally amount to 150 parts per million. On the other hand, in the diagrams illustrating Case 2 there is no similarity whatsoever between the curves for bacterial numbers and the corresponding curves for the amount of ammonia and nitrate present. The production of ammonia and nitrate, in fact, proceeds at the same rate in both soils, the initial advantage gained by the toluened soil never being improved upon in spite of the large difference in bacterial numbers. But in this soil the amount of 
ammonia is 180 parts per million, while the ammonia + nitrate is over 500 parts per million.

Further instances are given in Table XII.
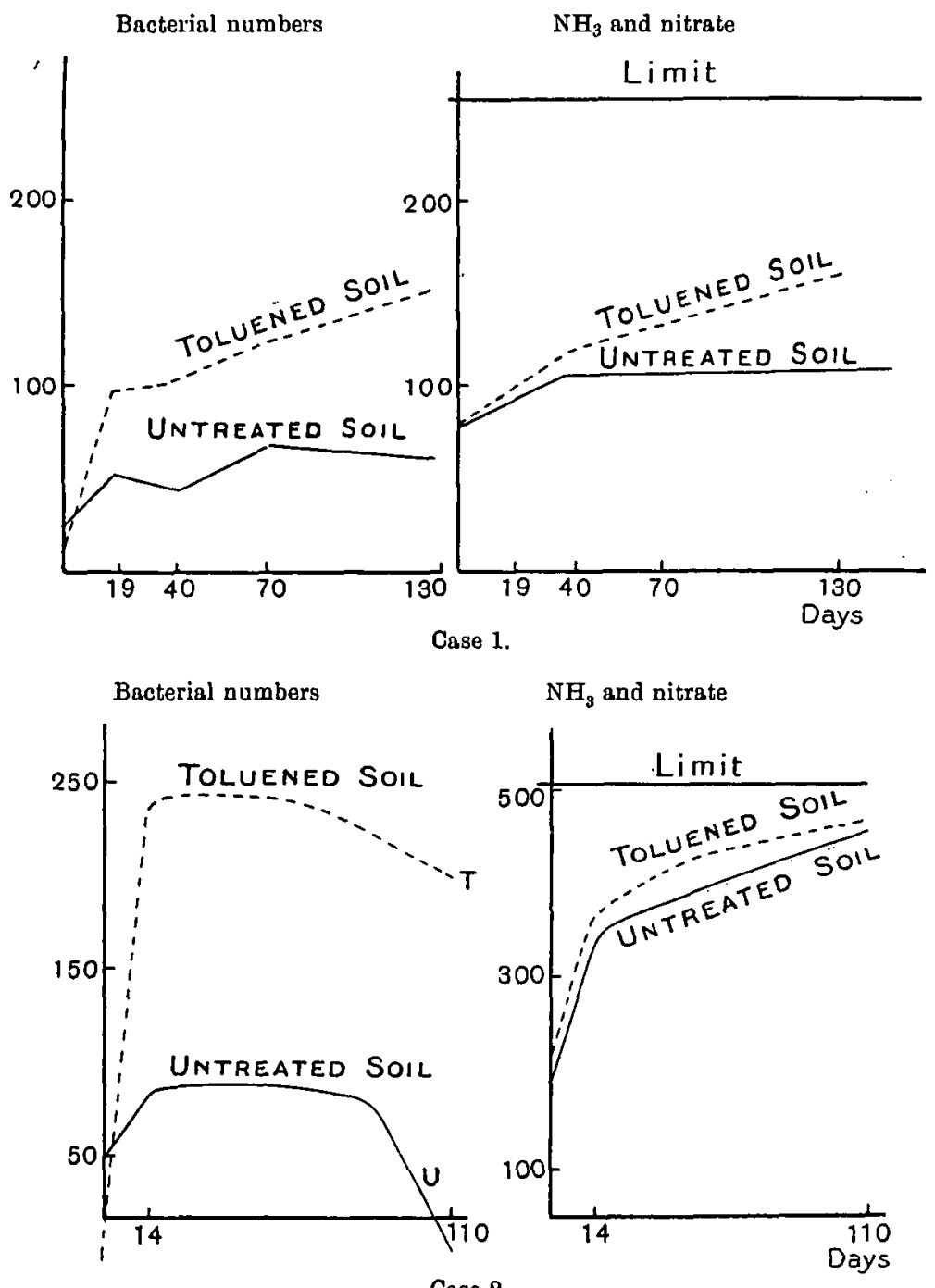

Case 2.

Fiy. 5. Relation between bacterial numbers and amount of nitrate and $\mathrm{NH}_{3}$ formed.

$\$ 39$. The falling off in the rate of accumulation of ammonia and uitrate is due to the ammonia and to a less extent to the nitrate already there, and not to the exhaustion of the complex precursors of ammonia 
194 Partial Sterilisation of Soil and Plant Food
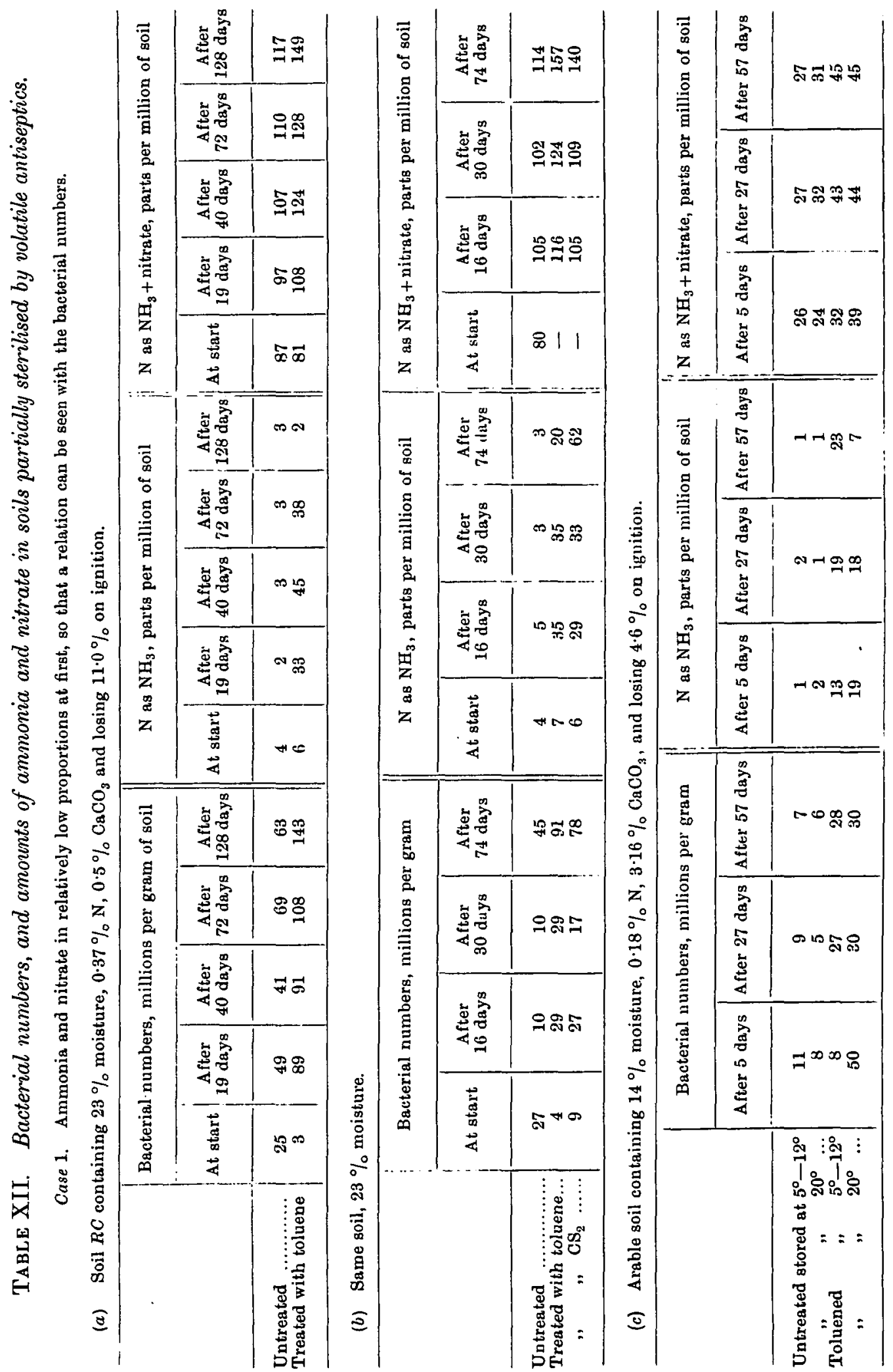
E. J. Russell and H. B. Hutchinson

195

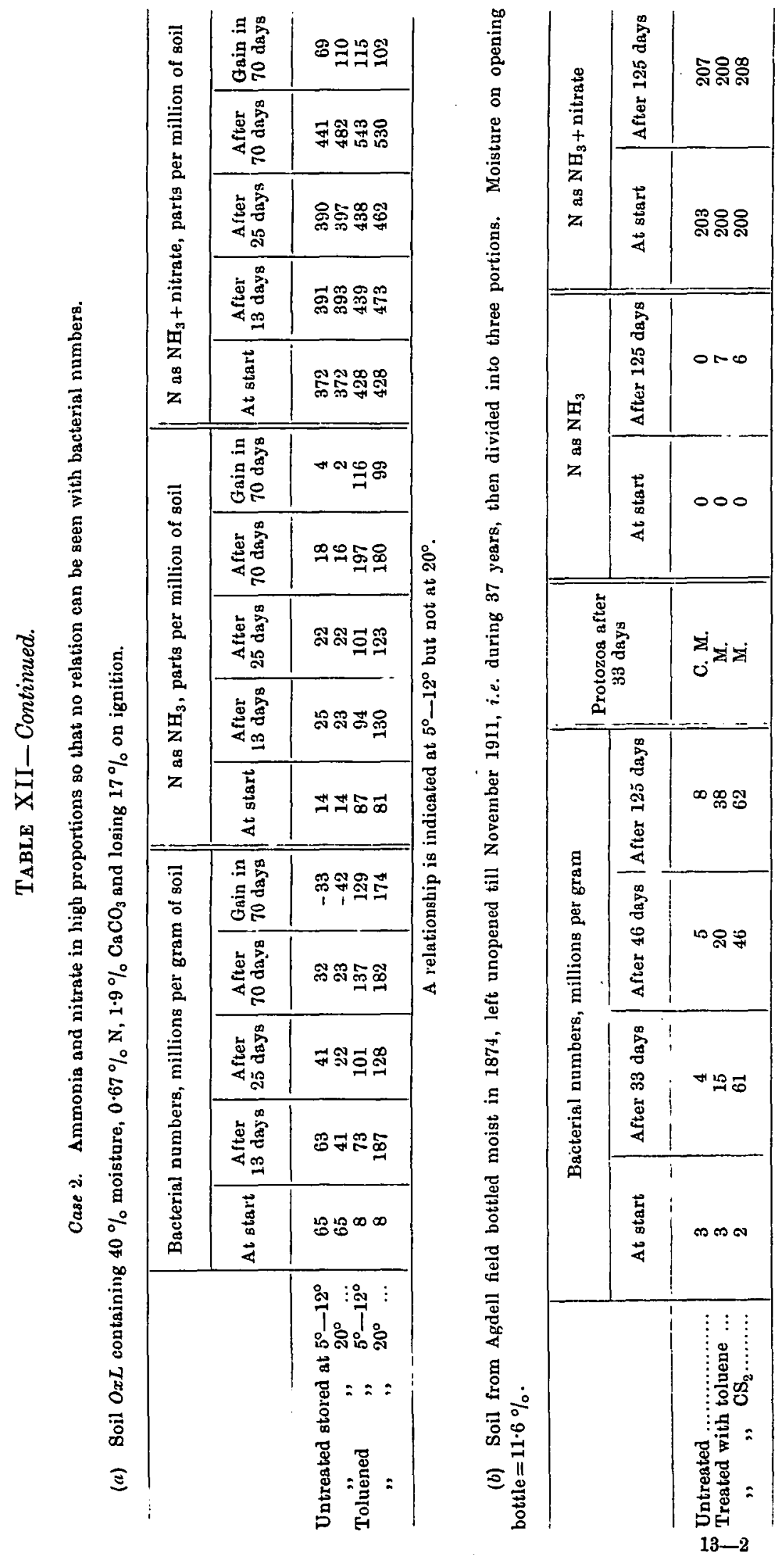


in the soil, since it can be brought about simply by adding suitable quantities of ammonium sulphate and sodium nitrate. The results of such an experiment are given in Table XIII and plotted in Fig. 6, showing the amounts of ammonia and nitrate formed in the soils of

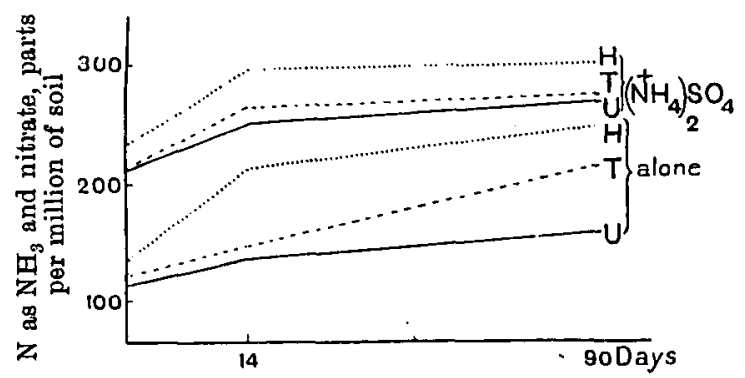

Accumulation of $\mathrm{NB}_{3}$ and nitrate in soil $R C$ by itself and after addition of ammonium sulphate.

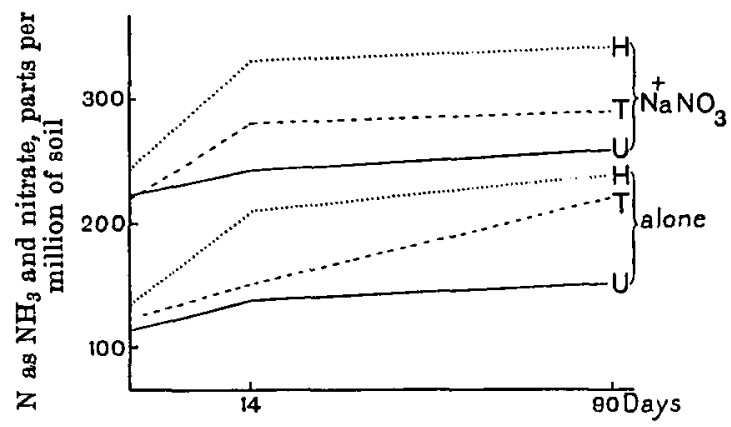

Accumulation of $\mathrm{NH}_{3}$ and nitrate in soil $R C$ by itself and after addition of $\mathrm{NaNO}_{3}$ (Table XIII, 1).

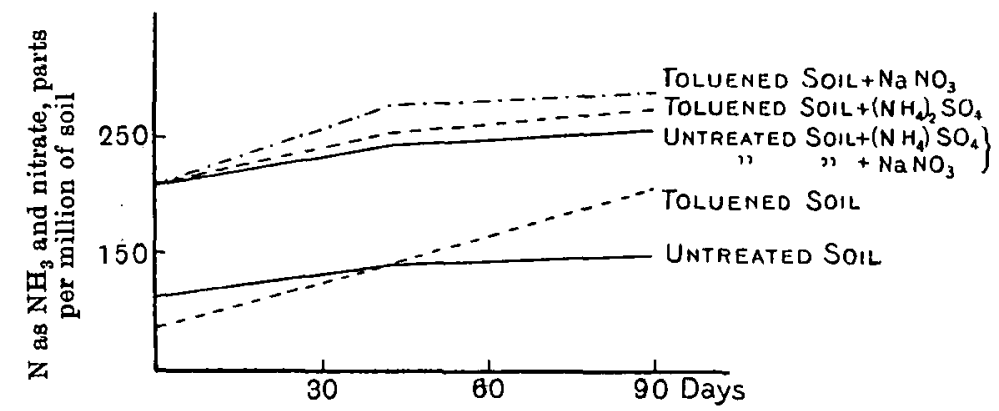

Accumulation of $\mathrm{NH}_{3}$ and nitrate in soil $R C$. Comparison of effects of $\mathrm{NaNO}_{3}$ and $\left(\mathrm{NH}_{4}\right)_{2} \mathrm{SO}_{4}$.

Fig. 6. Effect of additions of ammonium sulphate and sodium nitrate on the rate of accumulation of ammonia and nitrate in soils (Table XIII). 
Fig. 4 in presence of ammonium sulphate or sodium nitrate. The limiting effect on the decomposition is well seen. The soil $R C$ by itself behaves in the normal way, ammonia and nitrate accumulating on the toluened more rapidly than on the untreated soil. After addition of ammonium sulphate, however, the accumulation no longer goes on so quickly in the toluened soil, and the difference between the curves for this and the untreated soil becomes very small. Sodium nitrate also hus an effect but not as great as that of ammonium sulphate. The untrented soil (which is poorer in ammonia and nitrate) behaves differently; neither the addition of ammonium sulphate nor of sodium nitrate has reduced the rate of decomposition. But even at the end of the period the total amount of ammonia and nitrate in this soil still remains below the quantity present in the toluened soils.

$\S 40$. In soil $O x L$ a similar result is obtained. The rate of production of ammonia is at first much higher in the toluened than in the untreated soil. After addition of ammonium sulphate, however, the difference in the rates is considerably reduced, the toluened soil tammonium sulphate having in six weeks gained little more than the untreated soil + ammonium sulphate. Addition of sodium nitrate appears to be without effect. After the first period of six weeks a drop is observed in the amounts of ammonia and nitrate in the toluened soil and the toluened soil + ammonium sulphate, but not in the other soils. 'This drop is unusual, and we have rarely observed it in our numerous experiments ${ }^{1}$; the usual course is for the ammonia and nitrate either to remain unaltered or to increase.

$\$ 41$. Two causes may account for the limiting effect exerted by the added ammonium sulphate and sodium nitrate. We may suppose, as Bréal ${ }^{8}$ did, that the production of ammonia still continues but a reverse action sets in as soon as the amount of ammonia and nitrate reaches a certain limit, and assimilation of ammonia then takes place. In the numerous cases where the amounts of ammonia

1 We attribute it to loss of ammonia by volatilisation because we only get it where much ammonia is present and where there has been a distinct loss of water by volatilisation. Thus in the present instance the toluened soil and the toluened soil +ammonium sulphate contained initially $41.5 \%$ and $43.6 \%$ of water, whilst at the end they contained $37.4 \%$ and $35.2 \%$, losses of $4.1 \%$ and $8.4 \%$ respectively. The amounts of ammonia present reached the unusually high figures of 134 and 277 parts per million (nitrification being considerably retarded) and the falling off from the usual straight line on the curve (i.e. the amount we suppose to be lost) to 37 and 49 parts per million.

${ }^{2}$ Annales Agronomique, 1896, 22, 449. Bréal had observed that the production of ammonia went on when the nitrification was suspended by treatment with antiseptics, but soou came to an end. He explained this by assuming assimilation. 


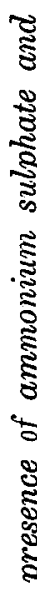

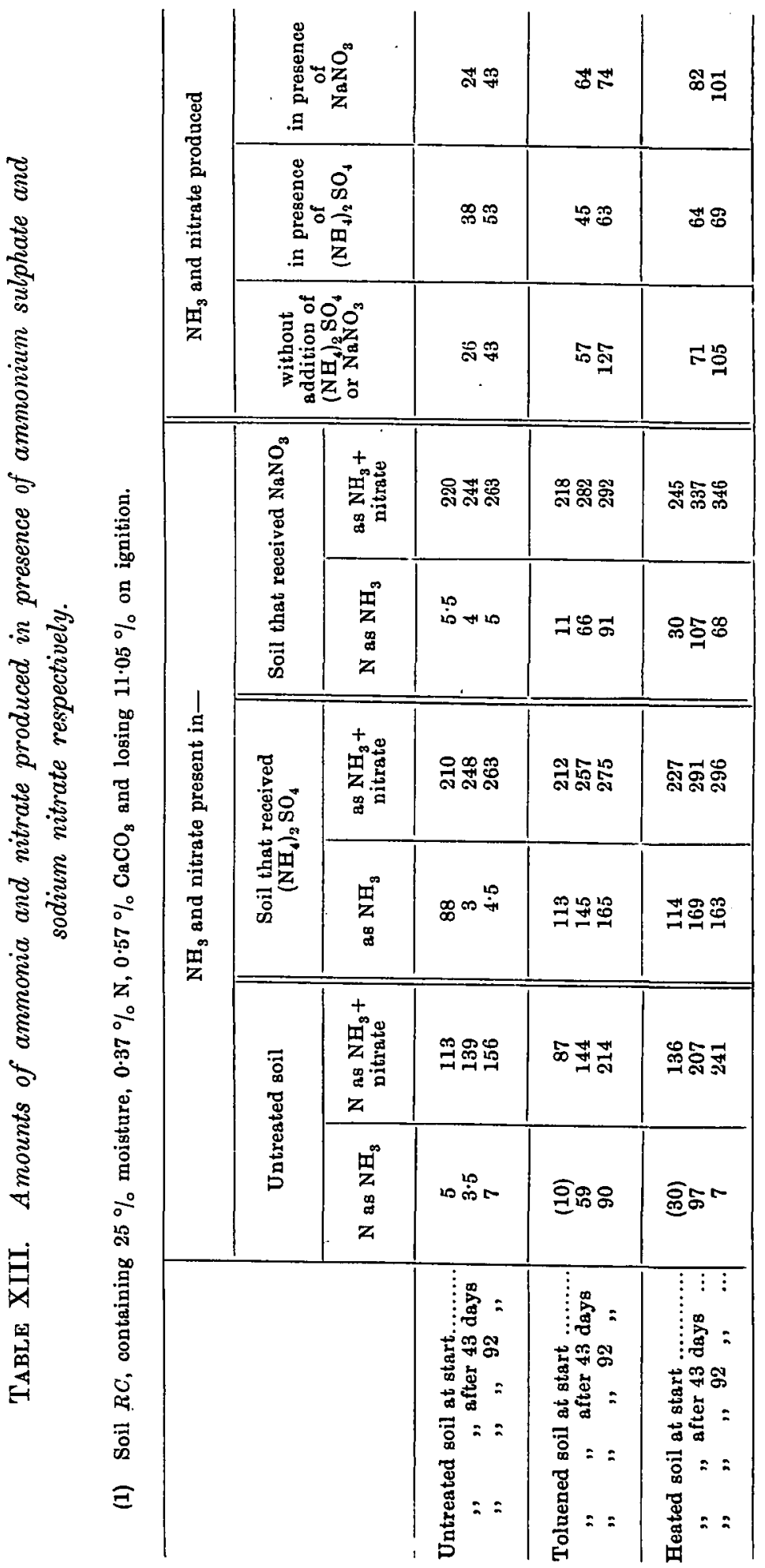


E. J. Russell and H. B. Hutrahinson

199

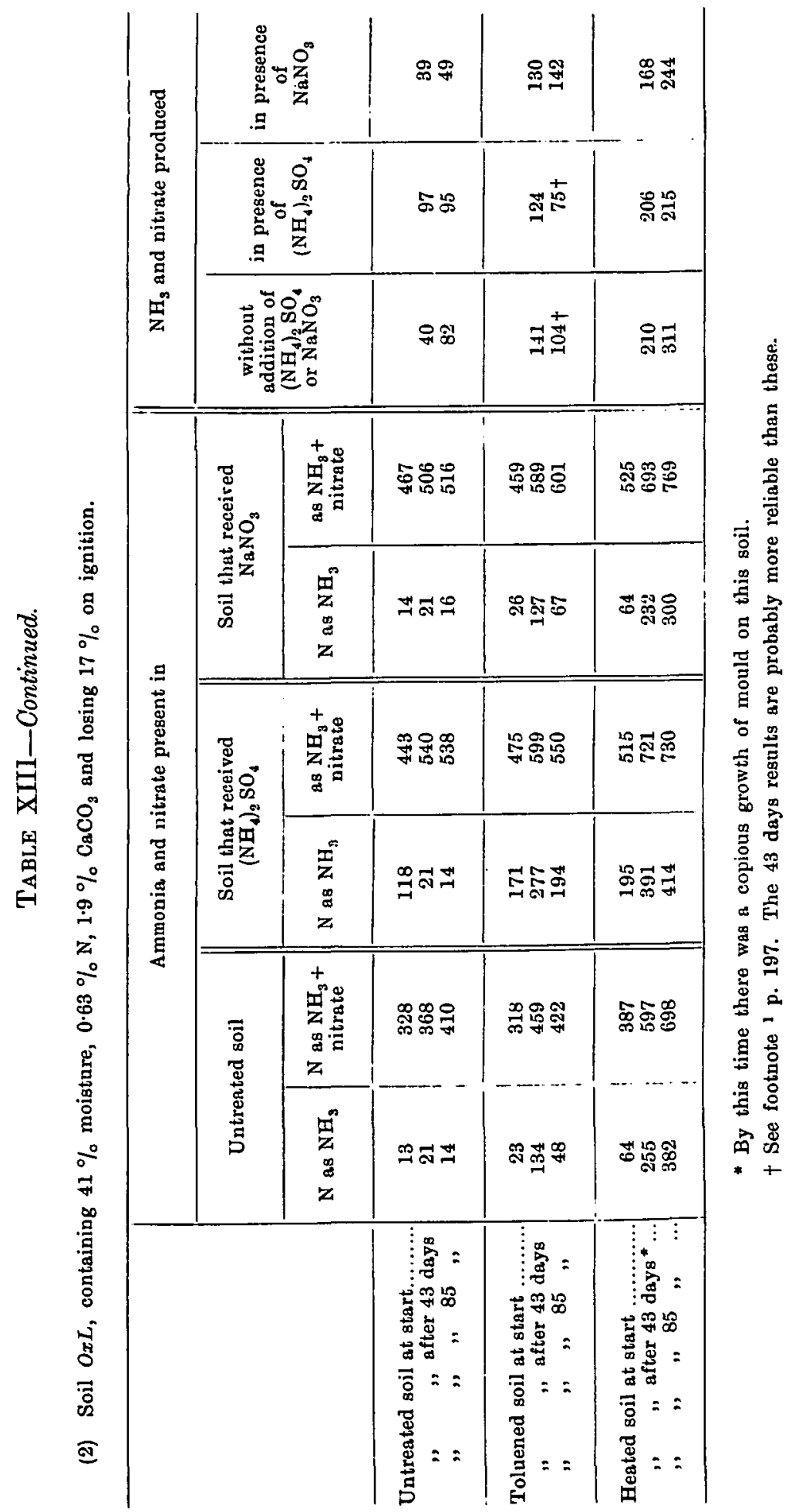


and nitrate remain constant we have further to suppose that the assimilation proceeds at the same rate as the ammonia production, so that only the excess over and above a certain quantity is assimilated. It is also necessary to assume an assimilation of nitrates on the same lines.

The simpler and more probable view is that ammonia production ceases in the soils as soon as a certain amount of ammonia and nitrate is present, the large quantity of ammonia and of soluble nitrates operating as a limiting factor and stopping ammonia production but not necessarily bacterial multiplication. The shape of the curves strongly supports this view, which is further in better accordance with the general nature of biochemical changes. We have also adduced evidence against the assimilation hypothesis in our earlier paper.

$\$ 42$. Table XIV shows that the further increase in numbers on the reintroduction of the original flora into the partially sterilised soil is frequently accompanied by further increases in the amount of ammonia and nitrate produced, but the rule is by no means universal. Whenever the amount of ammonia is high and that of ammonia + nitrate is getting towards the limit, there is a tendency for the rule to be broken.

$\S 4$ 4. Partial sterilisation by heat. The problem presented by heated soils is complicated by at least three disturbing factors. In the first instance heat effects a far more drastic reduction in the bacterial flora than toluene, so that the flora on a heated soil is much simpler than that on a toluened soil. Secondly, it causes a certain amount of decomposition of the organic matter, as is proved by the liberation of ammonia and the dark colour of the aqueous extract. This decomposition lightens the subsequent work of the bacteria with the result that the amount of ammonia and nitrate ultimately produced is much higher than when the partial sterilisation has beeu effected by antiseptics. Lastly, some of the decomposition products (we have not yet ascertained which) have a toxic action on bacteria so that multiplication does not go on as rapidly as in soils treated with toluene.

$\$$ 44. We do not propose to discuss these effects in detail. Their operation is seen in Table XV where the results of some of our experiments are set out. In 1 the maximum numbers of bacteria are found in the soil that has been heated to $65^{\circ}$, the lowest temperature above that at which the detrimental organisms are destroyed and bacteria can begin to multiply. The numbers are lower in soil heated to $75^{\circ}$ and a little lower in that heated to $85^{\circ}$, but very distinctly lower after 
heating to $100^{\circ}$, where in fact they are little if any above those in the untreated soil. Similar results are shown by 2 , indeed in all the cases so far examined we find maximum bacterial numbers in those soils that have been heated to the minimum temperature necessary to kill the detrimental organisms. Two causes seem to be at work. At this minimum temperature the extermination of the various species is less complete, and we have already seen ( $(26)$ that a mixed flora can occupy the ground more fully than a simpler one and so attain higher numbers. Also the toxic decomposition products are less in evidence. Soils heated to these minimum temperatures, in fact, closely resemble those treated with volatile antiseptics, since in both cases the secondary disturbances are at a minimum.

$\S 4.5$. But if the bacterial numbers are at a minimum in the soils heated to $100^{\circ}$ the decomposition effected is at a maximum. There are only a few exceptions to this rule when the amounts of ammonia and nitrate are taken as the measure of the decomposition, and none when the amount of nitrogen assimilated by the plant is taken.

$\S 46$. The conclusion to which our experiments lead is that a relationship can generally be traced between the bacterial numbers and amount of decomposition in soils that have been heated to $55^{\circ}-60^{\circ}$ (this being the minimum necessary for killing the destructive organisms), just as it can in soils treated with volatile antiseptics; the same limitations also hold in both cases. But no such relationship exists in soils that have been heated to $100^{\circ}$.

Drying the soil has the same effect as heating to low temperatures (Tables VI and XV).

\section{The re-establishment of the original flora, and the introduction of the detrimental organisms.}

$\$ 47$. The results of typical experiments on this subject are given in Table XIV. In (1), an arable soil was used containing initially much less ammonia and nitrate ( 8 parts) than the soil can stand (over 60 parts). In accordance with the general rule we find that the increase in bacterial numbers brought about by partial sterilisation is accompanied by an increase in the amount of ammonia and nitrate in spite of the accumulation of ammonia (see $\$ 38$ ): while the increase in numbers brought about by the addition of bacteria from the untreated soil leads to still further production of ammonia and nitrate. (The ammonia, it should be noted, disappears during the process.)

$\$ 48$. The falling off in bacterial numbers in the infected soils is accompanied by a falling off in the production of ammonia and 
202 Partial Sterilisation of Soil and Plant Food

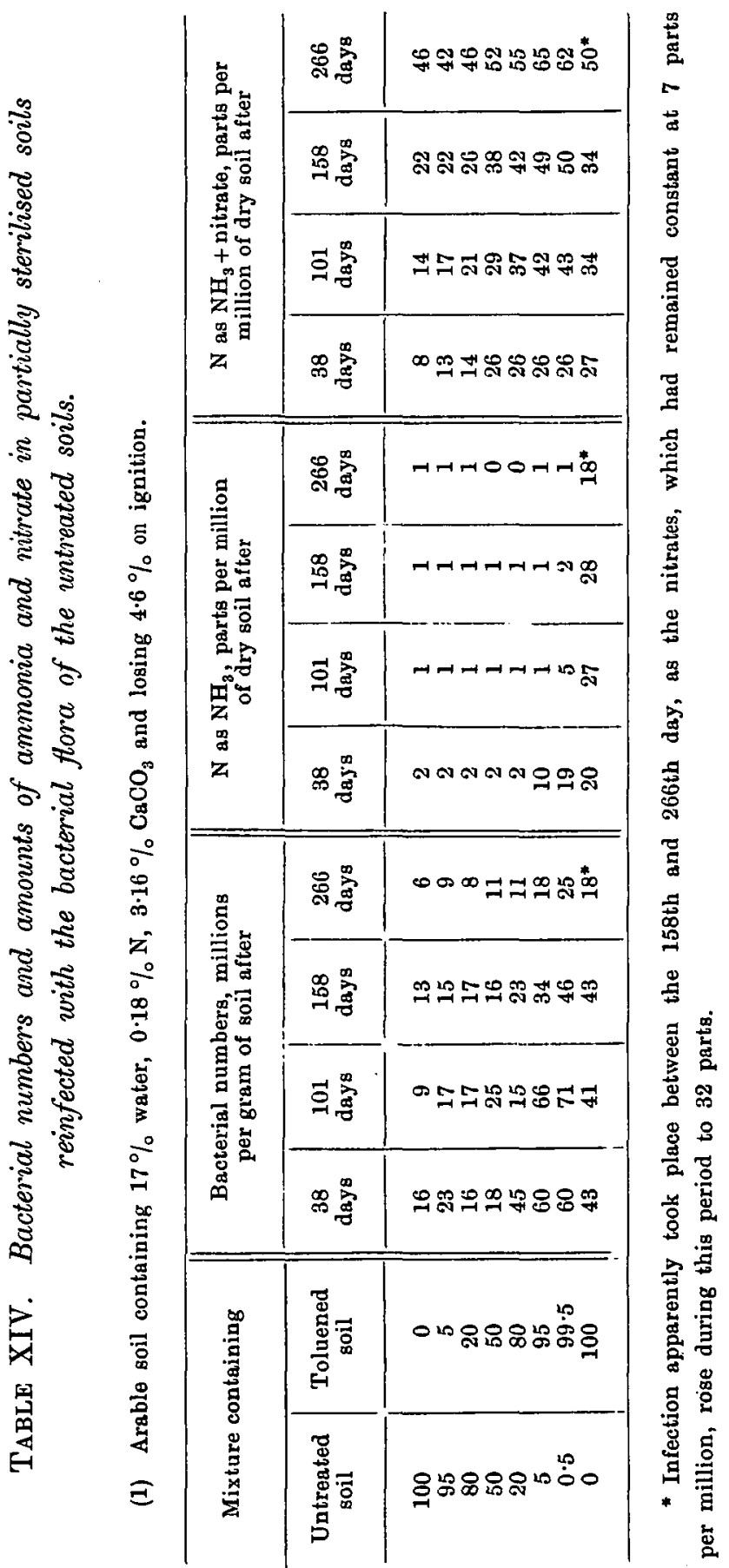




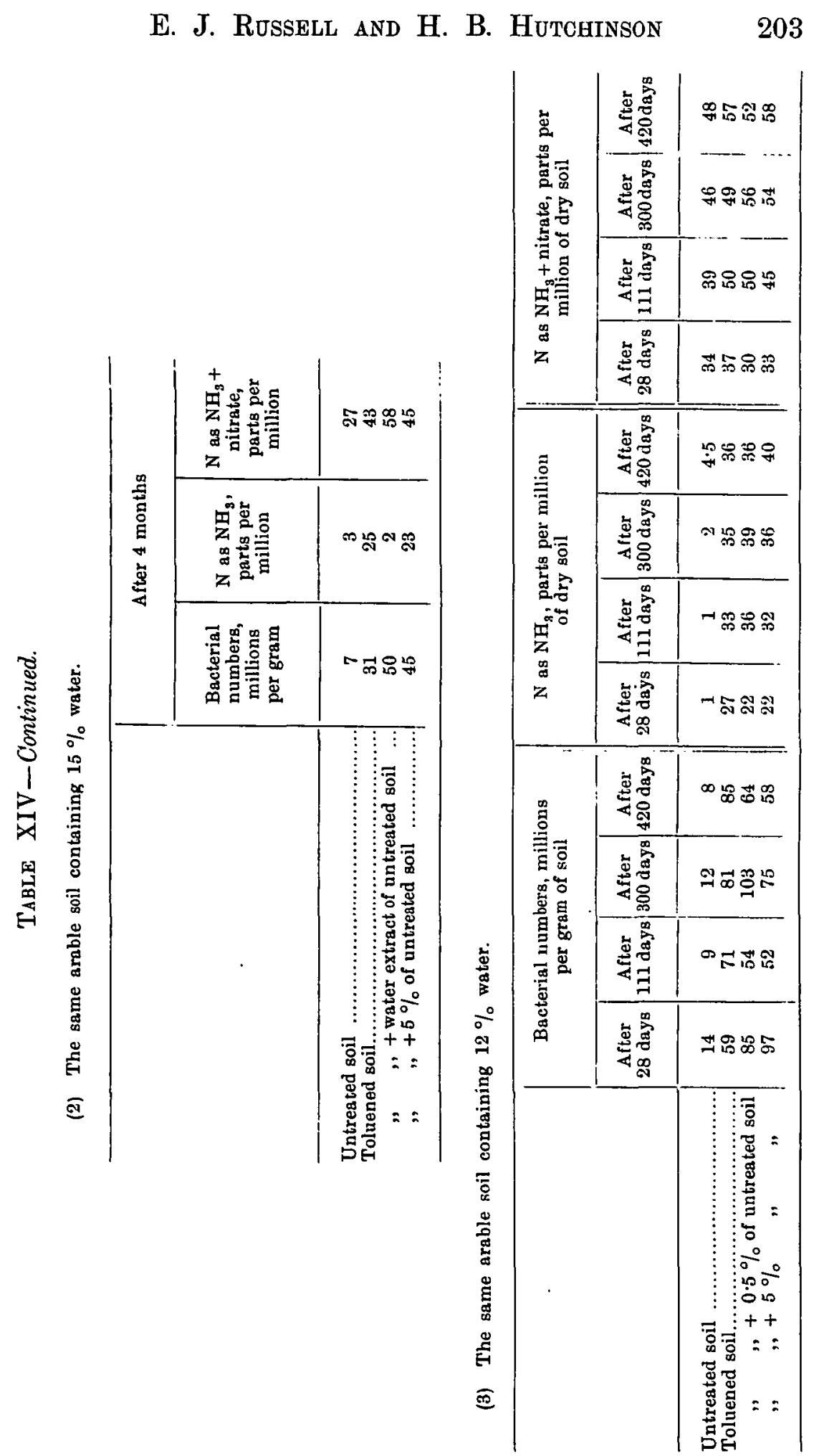


204 Partial Sterilisation of Soil and Plant Food

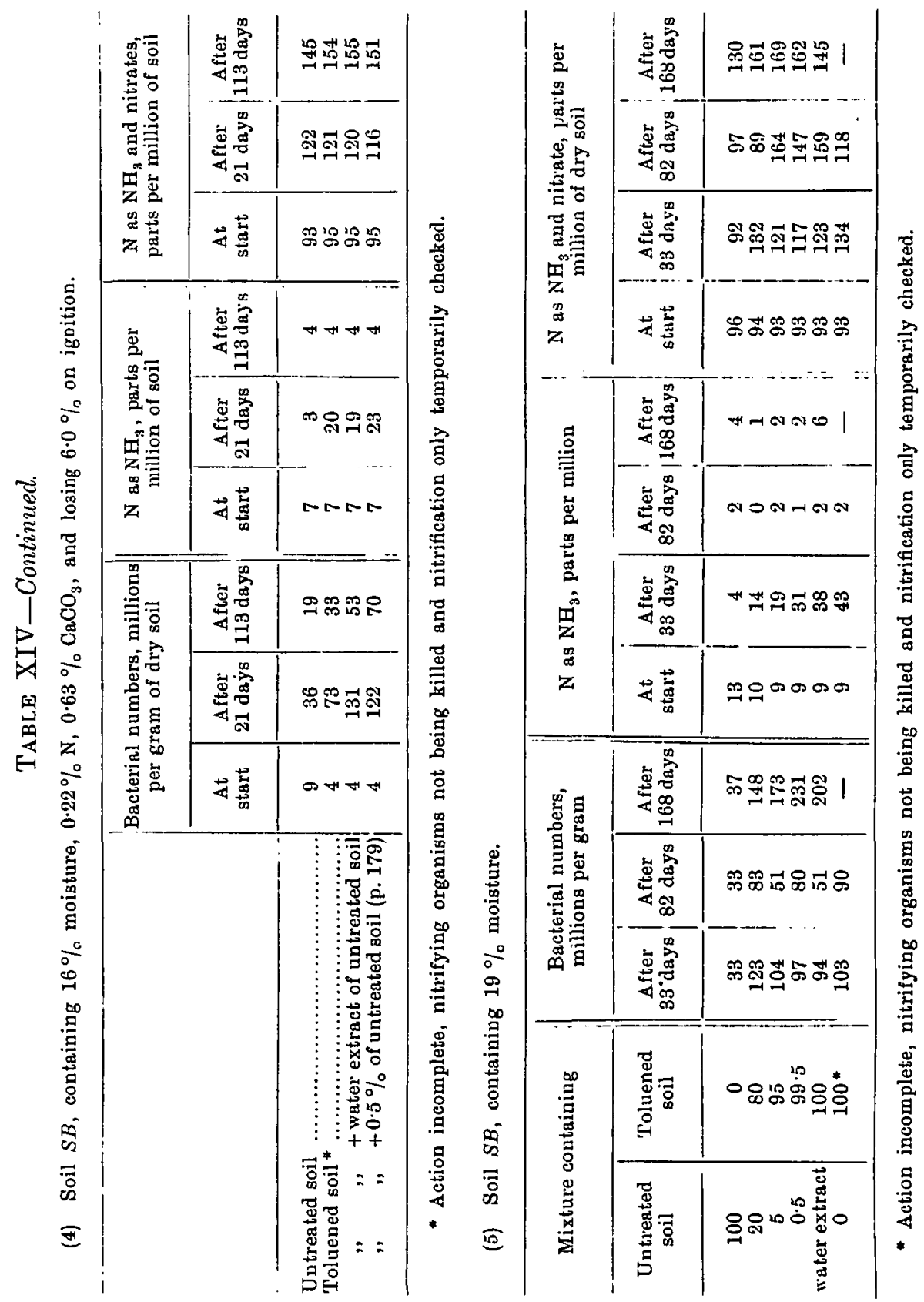


E. J. Russell and H. B. Hutchinson

205

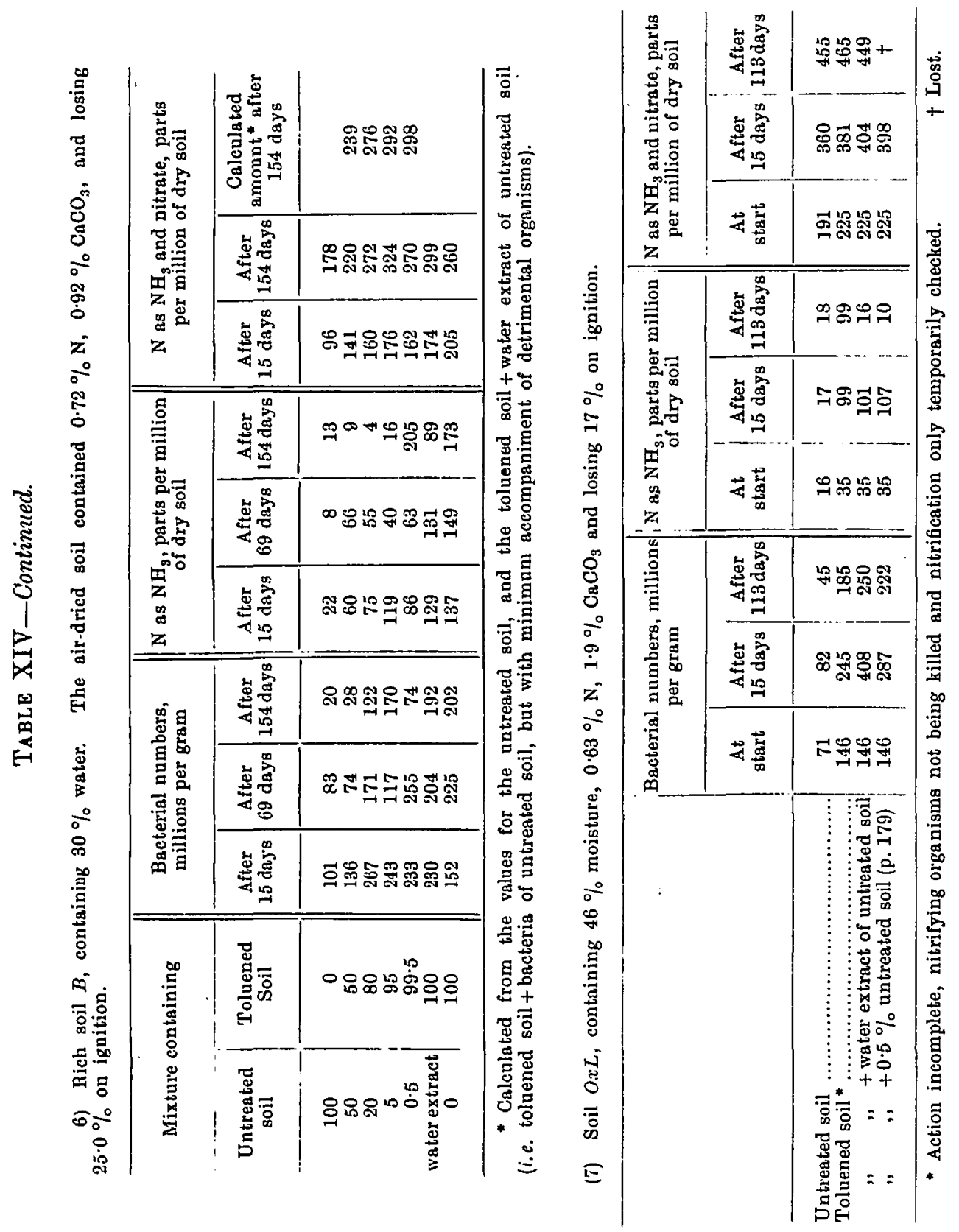




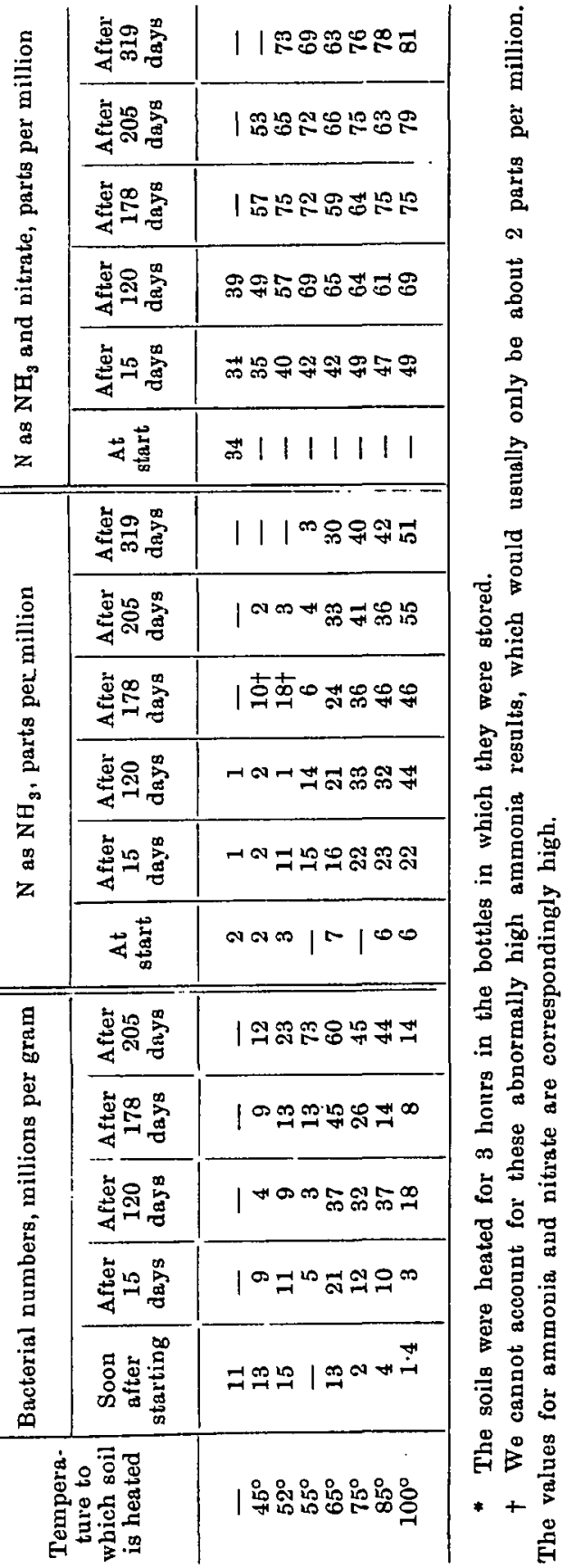

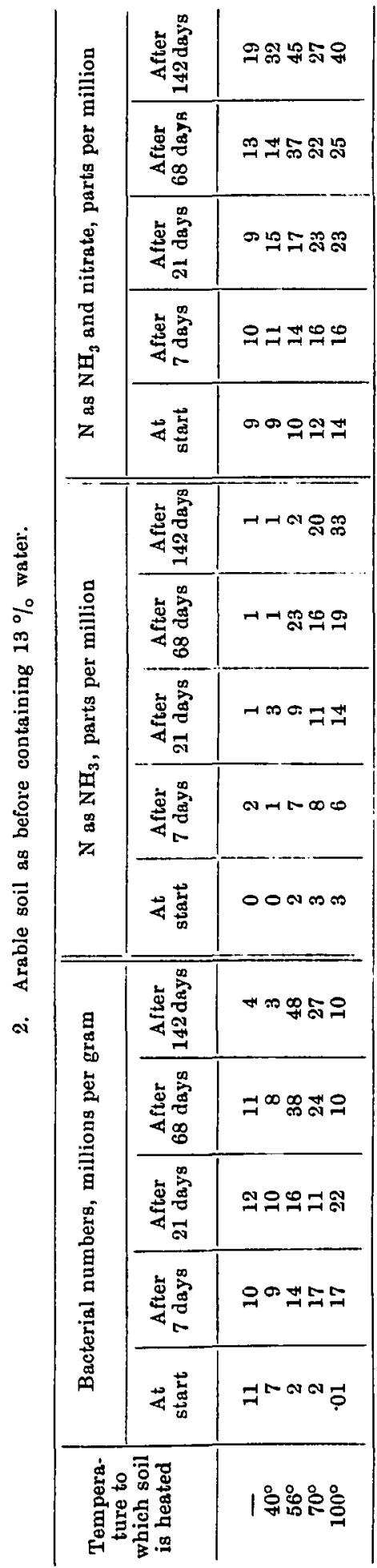




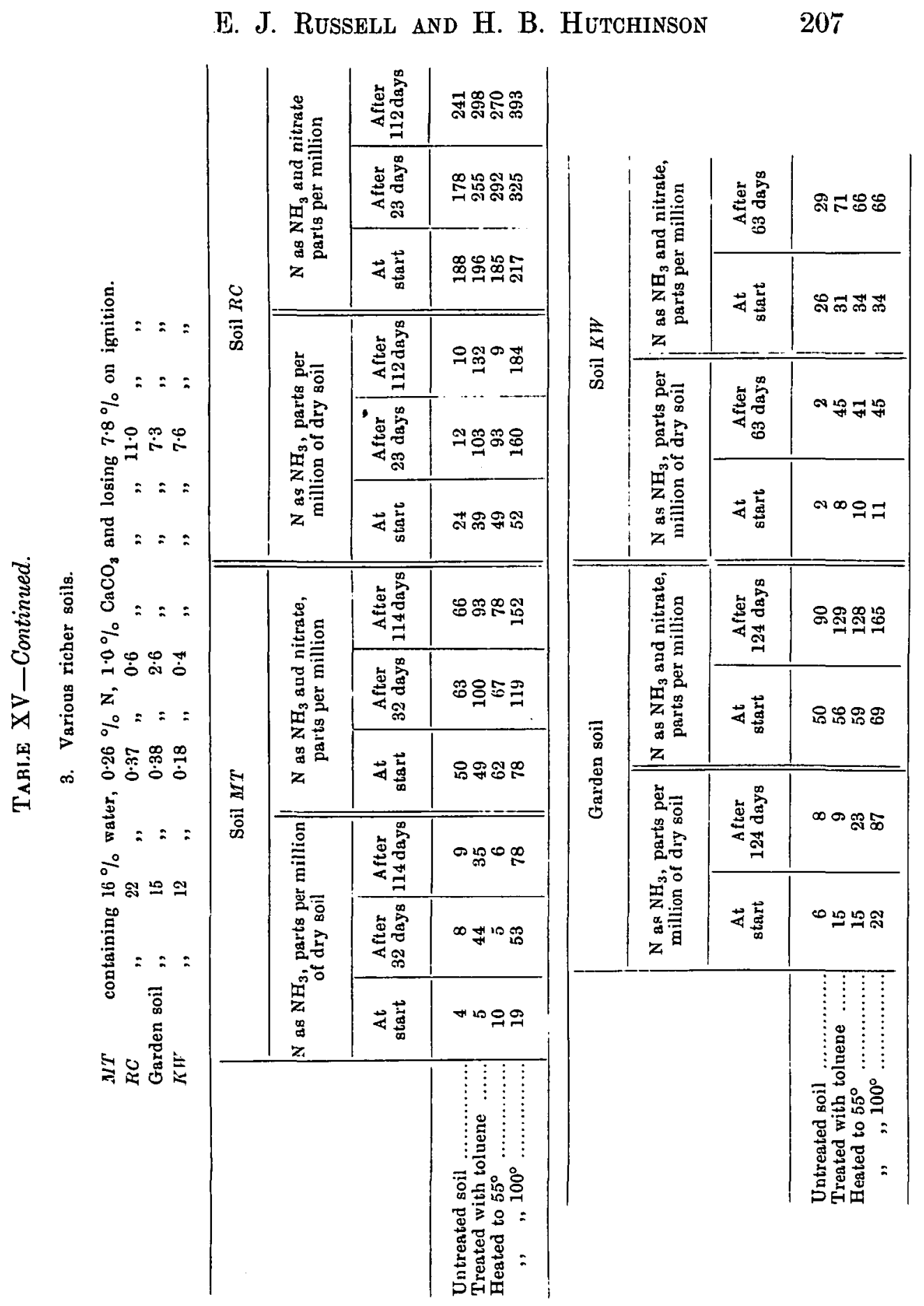


208 Partial Sterilisation of Soil and Plant Food

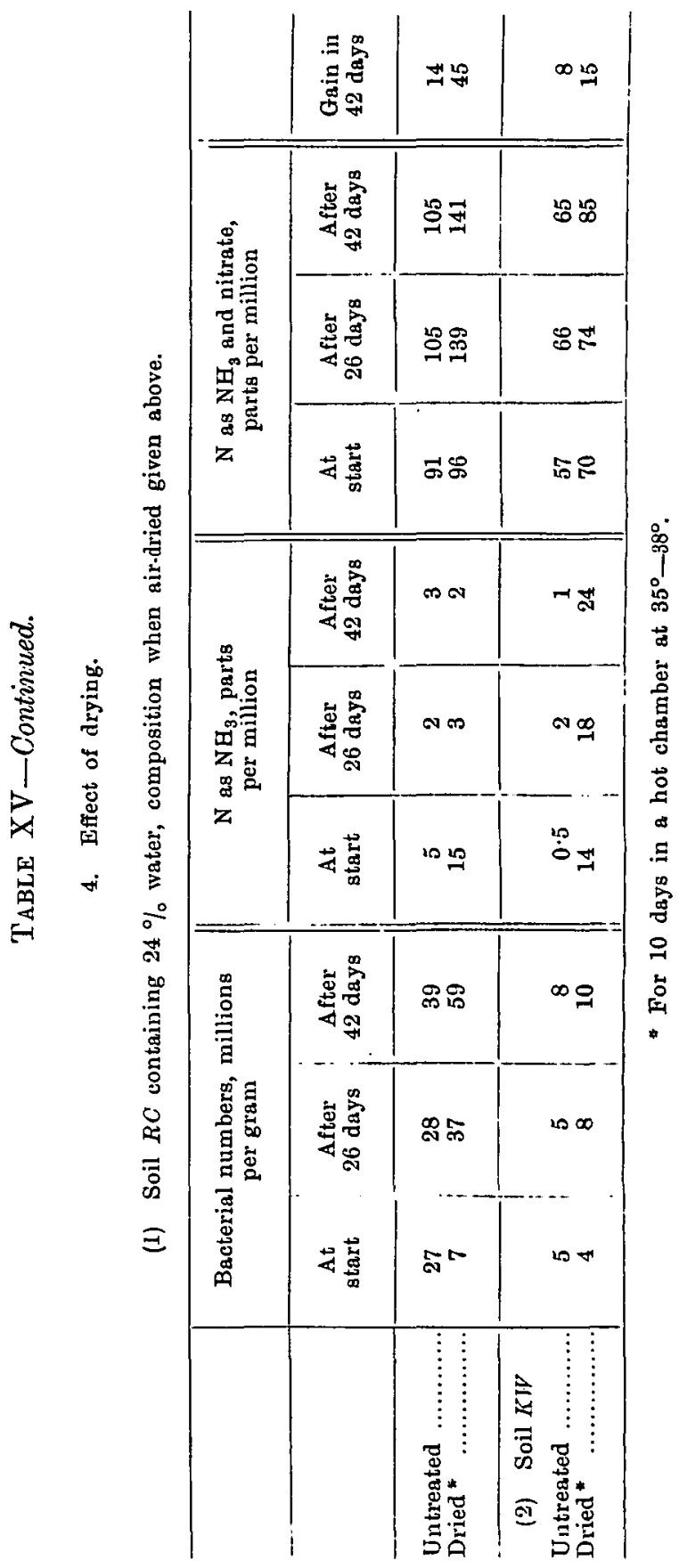


nitrate. But we know that this would have happened in any case as the result of the accumulation of ammonia and nitrate already formed and we cannot therefore conclude that it is connected with the drop in bacterial population. Indeed the decomposition has already gone so far before the reduction in bacterial numbers sets in-two-thirds of the final quantity of ammonia and nitrate being already formed, and the remaining one-third being on its way'-that but little work remains to be done.

$\$ 49$. Entirely similar results were obtained in other experiments with arable soils, and in some of the experiments with richer soils. In (6) for instance (same Table), the bacterial numbers are at first much higher in the infected soils than in the toluened soil and the amount of decomposition subsequently becomes higher. But even after five months, when the process is well on to completion, there is no evidence that the fall in bacterial numbers has adversely affected the rate of accumulation of ammonia and nitrate, for the quantities actually found correspond fairly well with the numbers calculated on the assumption that the untreated soil and the toluened soil + water extract of untreated soil (i.e. toluened soil + bacteria of untreated soil but with minimum accompaniment of detrimental organisms) are inert to one another.

On the other hand, instances have also been observed where the drop in bacterial numbers is accompanied by a marked falling off in the rate of decomposition?

$\S 50$. The other experiments recorded in the Table illustrate the case where a large amount of ammonia, or of ammonia and nitrate, has already accumulated, and where fresh accumulation is no more rapid than in the untreated soils. No relationship therefore exists between bacterial numbers and rate of decomposition.

$\$ 51$. The conclusion to be drawn from these experiments is that the increased bacterial numbers resulting from the introduction of the original flora into the partially sterilised soil leads to an increased production of ammonia and nitrate unless too large a quantity of these substances is already present. But the subsequent depression in bacterial numbers consequent on the development of the detrimental organisms is generally (though not always) without effect on the rate of decomposition, apparently because it does not set in until too late.

I Wo have shown in our previous paper that the amount of unstable intermediate products as well as of ammonia is increased by partial sterilisation.

'E.g. this Journal, 1912, s, 98.

Journ. of Agric. Sci. v 


\section{Partial Sterilisation of Soil and Plant Food}

The effect of varying temperatures of incubation on the changes taking place in partially sterilised soils.

$\S 52$. The experiments dealt with in the preceding sections were mainly carried out at the ordinary laboratory temperature. A series was now undertaken at higher temperatures, the bottles of soil being stored in incubators maintained respectively at $20^{\circ}, 30^{\circ}, 40^{\circ}$ and $50^{\circ}$. The results obtained are set out in Table XVI.

We have already dealt with the bacteriological data and need now only point out that an increase in temperature from $10^{\circ}$ to $20^{\circ}$ fails to increase the bacterial numbers in the untreated soil, but it does increase them in the toluened soil, a fact that has been fully discussed in $\$ 4$ and 5 . The bacterial numbers attain a maximum in the soil stored at $20^{\circ}$ though they are still high at $30^{\circ}$, they fall off rapidly at $40^{\circ}$ and still more completely at $50^{\circ}$. At these two higher temperatures there is no difference in bacterial numbers in the toluened and the untreated soils. The curves obtained in studying one of the soils are given in Fig. 7 .

The rate of accumulation of ammonia and nitrate is connected with the bacterial numbers only in the toluened soils kept at $5^{\circ}-12^{\circ}$ and at $20^{\circ}$. The bacterial numbers increase at $20^{\circ}$ in comparison with those at the lower temperature and so also does the rate of accumulation of ammonia and nitrate until the usual falling off sets in, when the relationship ceases to exist. In all other cases there is a complete absence of any sort of relationship. The rate of accumulation of ammonia and nitrate is greater at $20^{\circ}$ than at $5^{\circ}-12^{\circ}$, although the same limit may be reached in both cases; it is also generally greater in the toluened soil than in the untreated soil. At $30^{\circ}$ it is still greater and in all but one instance it proceeds much further than at the lower temperatures; it becomes rapid at $40^{\circ}$ and still more so at $50^{\circ}$ and proceeds at each temperature to a correspondingly higher extent. We get, therefore, a series of curves in which the rate of accumulation of ammonia and nitrate successively increases with increasing temperature and in which also the extent of the accumulation also increases-to a small extent-at first but very much afterwards. This is wholly unlike the series obtained for bacteriai numbers, excepting, as above mentioned, on the toluened soils at about $10^{\circ}$ and $20^{\circ}$.

$\S 53$. Thus we have another exception to the rule that bacterial numbers are connected with the rate of accumulation of ammonia and 
nitrates. But it is not necessarily a significant exception, for the decomposition at the higher temperatures may be a chemical process wholly unconnected with bacteria!. For the present we prefer to leave this
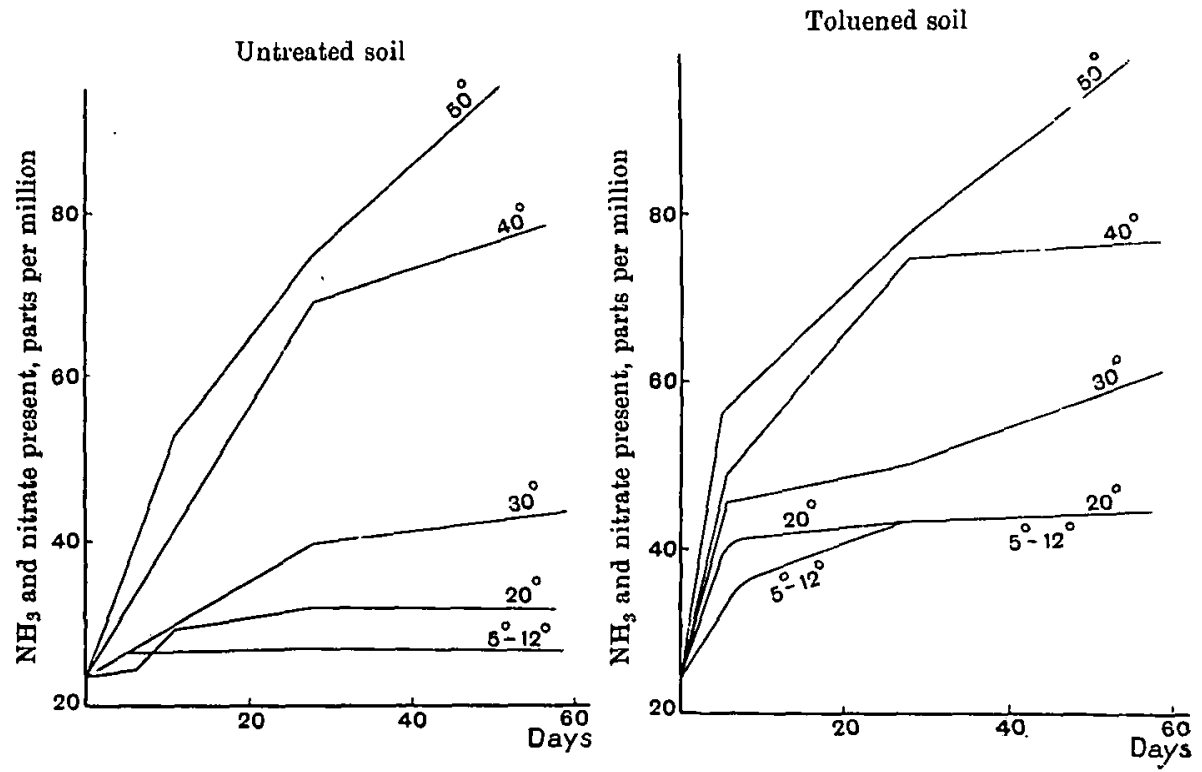

Bacterial numbers in untreated soil

Bacterial numbers in toluened soil
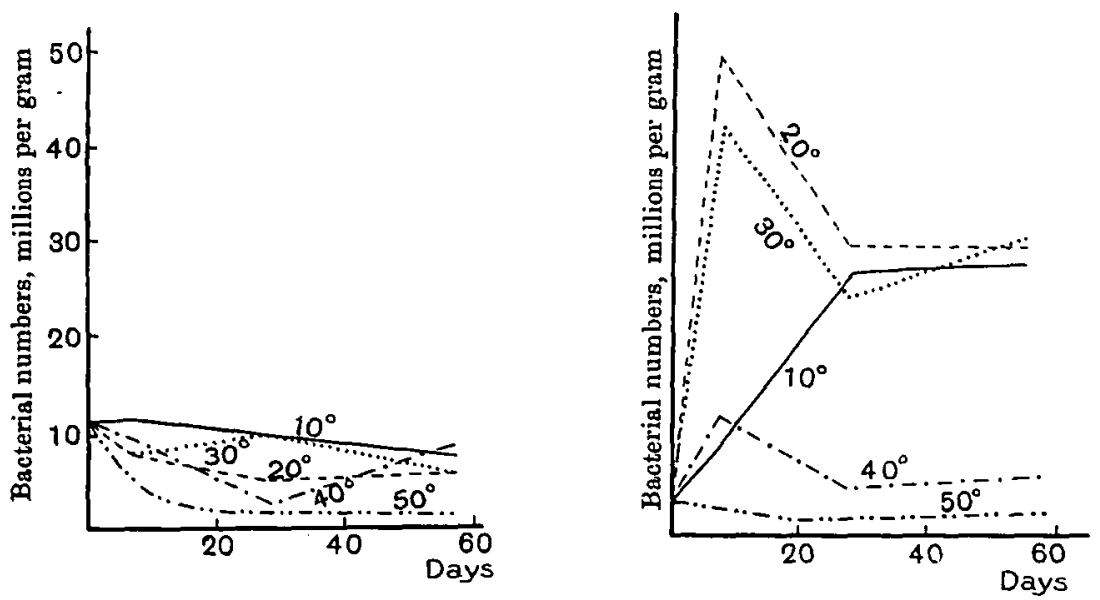

Fig. 7. Effect of varying temperatures of storage on the rate of accumulation of ammonia and nitrate in soils (Table XVI, arable soil).

1 It will be noticed that ammonia accumulates in the soils maintained at $40^{\circ}$ and over, showing that the nitrifying organisms no longer work much, if at all. 
212 Partial Sterilisation of Soil and Plant Food

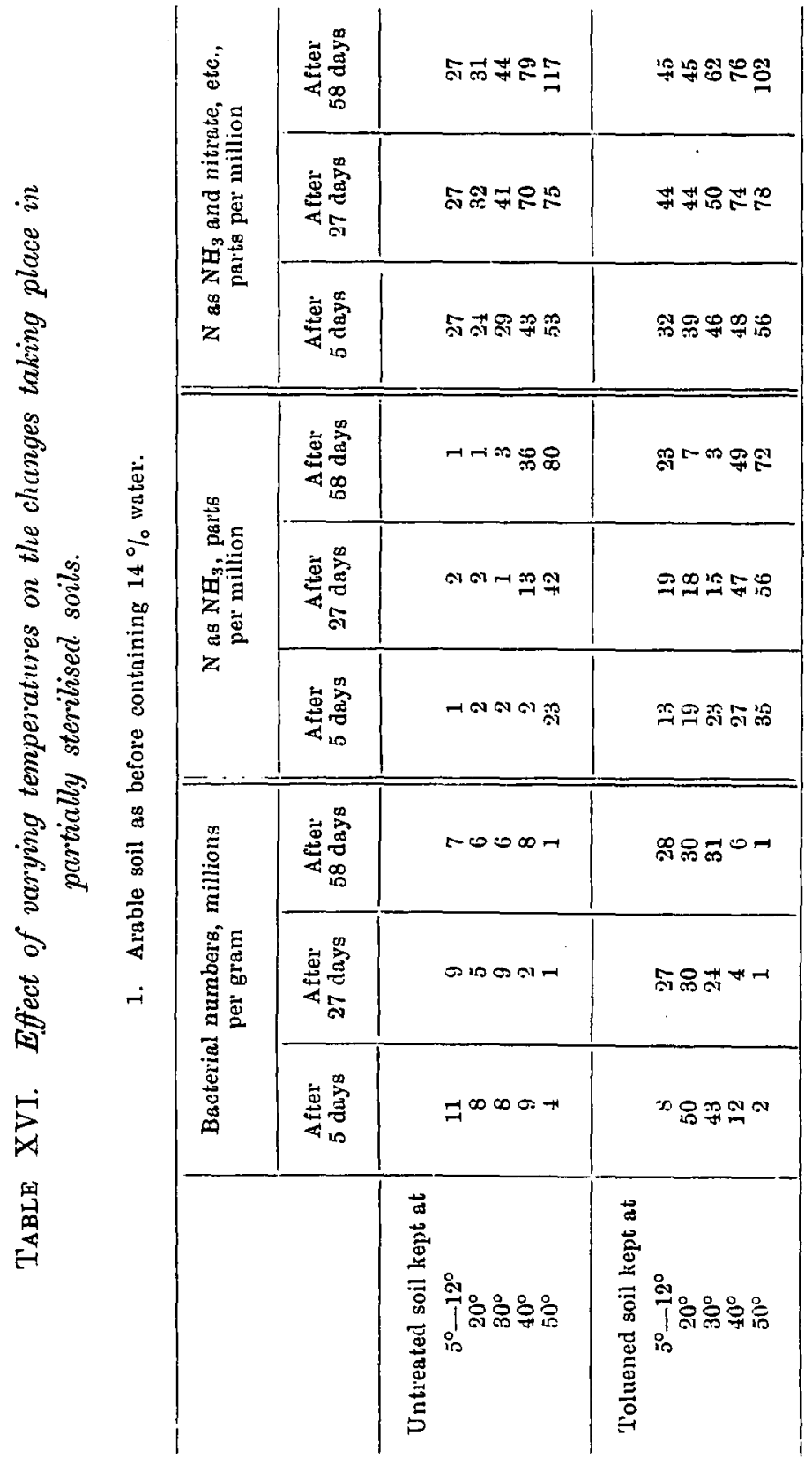


E. J. Russell and H. B. Hutchinson

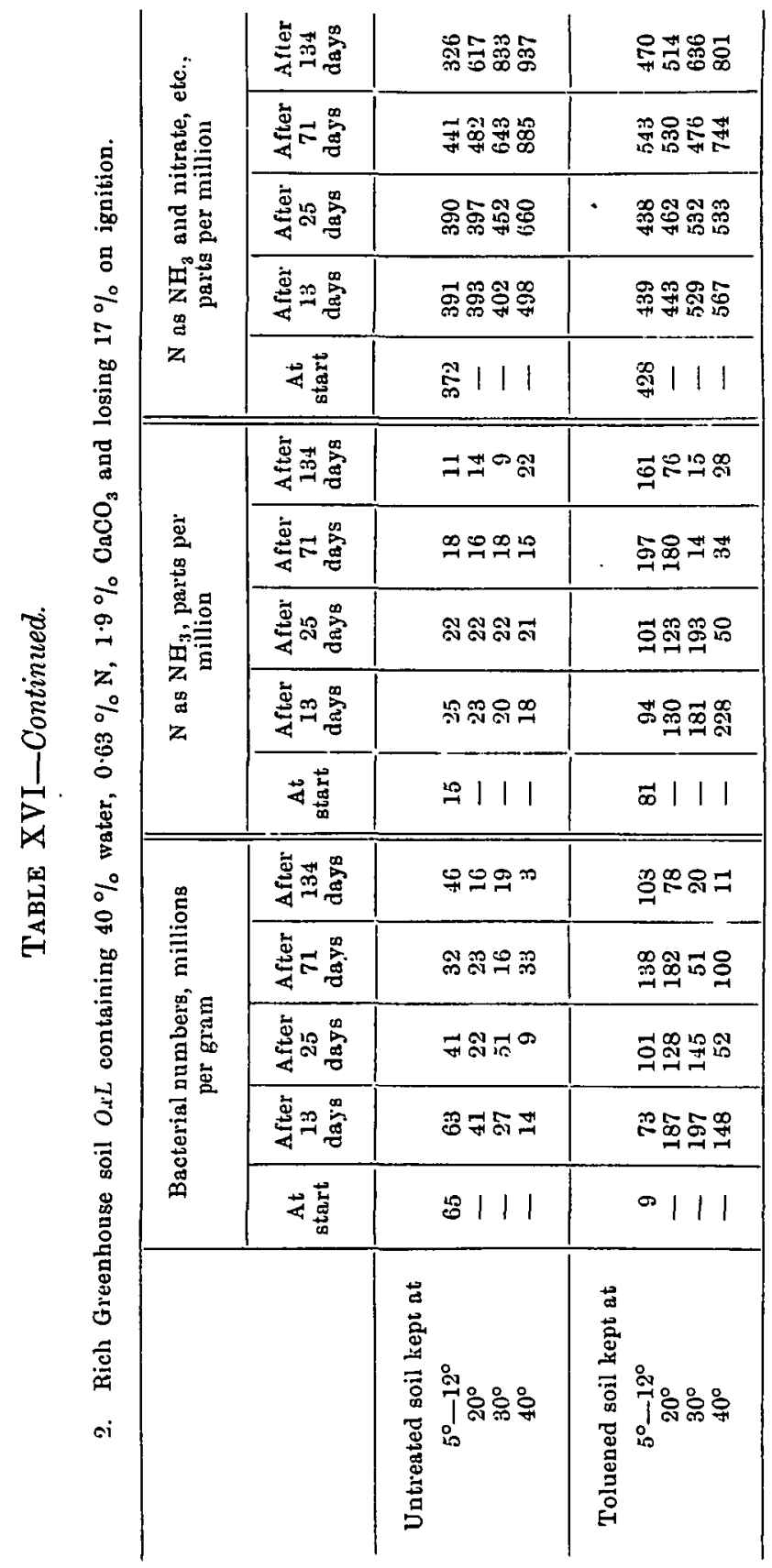




\section{Partial Sterilisation of Soil and Plant Food}

question undecided until other investigations now in hand of the chemical processes are further advanced. It may also be doubted whether our method of counting is applicable to the soils stored at higher temperatures. Gelatine plates kept at $20^{\circ}$ may not provide suitable conditions for the development of such thermophilic organisms as may be active in a soil maintained at $40^{\circ}$.

$\S 54$. It is possible to treat the curves mathematically after the methods adopted by physical chemists, but the data are hardly fine enough since the error of the determinations becomes rather considerable at the higher temperatures. There is an unknown loss of ammonia (see footnote, p. 197) and there also appears to be a production of reducible substances not present in appreciable amounts in ordinary soils, but giving rise to ammonia on reduction with the zinc-copper couple, and therefore appearing in the analytical results as nitrates.

The effect of additional food on bacterial numbers and the rate of decomposition.

$\S 55$. It has already been pointed out that all the antiseptics used have some direct action in the soil which is shown in our experiments by a liberation of ammonia. We therefore have to consider the possibility that other substances may be set free capable of acting as food for bacteria, and it becomes necessary to ascertain how added foodstuffs affect the bacterial numbers and the amounts of decomposition. We have limited ourselves to three substances: sugar, hay dust and peptone.

\$56. All of these substances cause the bacterial numbers to go up rapidly for a time, but there is no corresponding increase in the amounts of ammonia and nitrate such as is obtained on partial sterilisation. Sugar, indeed, causes a marked loss of nitrate and no increase in ammonia; hay dust has a similar but less marked action, whilst peptone fails to increase the stock of ammonia and nitrate even by the full amount of the nitrogen it contains. Supposing therefore any foodstuff to be liberated by the antiseptics used we should expect it to increase the bacterial numbers but not necessarily the ammonia and nitrate. This would happen only if the liberated substances themselves gave rise to the extra ammonia and nitrate, i.e. if they were easily decomposable after contact with antiseptic vapours, but not before. 
The limitations of the methods for counting bacteria.

$\$ 57$. Three facts stand out prominently on reviewing the whole of the data obtained at ordinary temperatures (i.e. not above $20^{\circ}$ ):

(1) An increase in bacterial numbers effected by partial sterilisation commonly causes an increase in the amounts of ammonia and nitrate.

(2) But if a large amount of ammonia or of ammonia and nitrate is already present in the soil the increased bacterial numbers do not necessarily bring about more production of these substances.

(3) Whenever an increase in the rate of production of ammonia and nitrate is obtained there is always an increase in bacterial numbers 1 .

(2) and (3) may also be expressed thus: bacterial multiplication may take place without an increased rate of production of ammonia and nitrate, but an increased rate of production of ammonia and nitrate does not occur without bacterial multiplication.

$\S 58$. In some of our experiments the relation between bacterial numbers and amounts of ammonia and nitrate is fairly close (e.g. Fig. 4, Case 1), but more usually this is not so. From what we know of the limitations of the counting method indeed, we should hardly expect it to be otherwise. Some of the soil bacteria are more vigorous ammonia producers than others, some are not even active but only occur as spores. Yet all these are grouped together without any distinction. Further, the method does not even give the actual total but misses altogether those organisms that fail to develop on the plates employed; there is, in fact, no method for estimating the total number of bacteria in the soil.

$\S 59$. The question therefore arises, how far do the numbers revealed by any particular plate possess any significance? The data for a complete answer do not exist, but there is considerable evidence that on one and the same soil under strictly comparable conditions the fluctuations in the numbers growing on gelatine plates afford a satisfactory index of the fluctuations in the total numbers of decomposition bacteria. When therefore we find that partial sterilisation has increased the bacterial numbers revealed by our plates from 20 to 40 millions per gram we do not imply that the true totals have doubled under the treatment, but that they have increased; the exact amount of increase we cannot as yet specify. Further, we only institute the comparisun where the conditions are otherwise identical; the untreated

\footnotetext{
1 In the course of four years we have only found one exception. The results obtained at $30^{\circ}, 40^{\circ}$ and $50^{\circ}$ are expressly excluded here.
} 
216 Partial Sterilisation of Soil and Plant Food

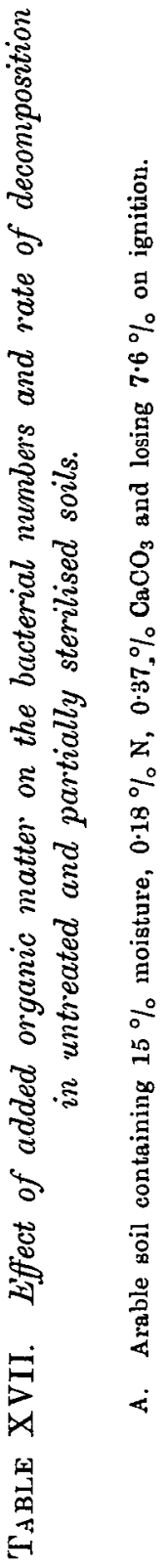

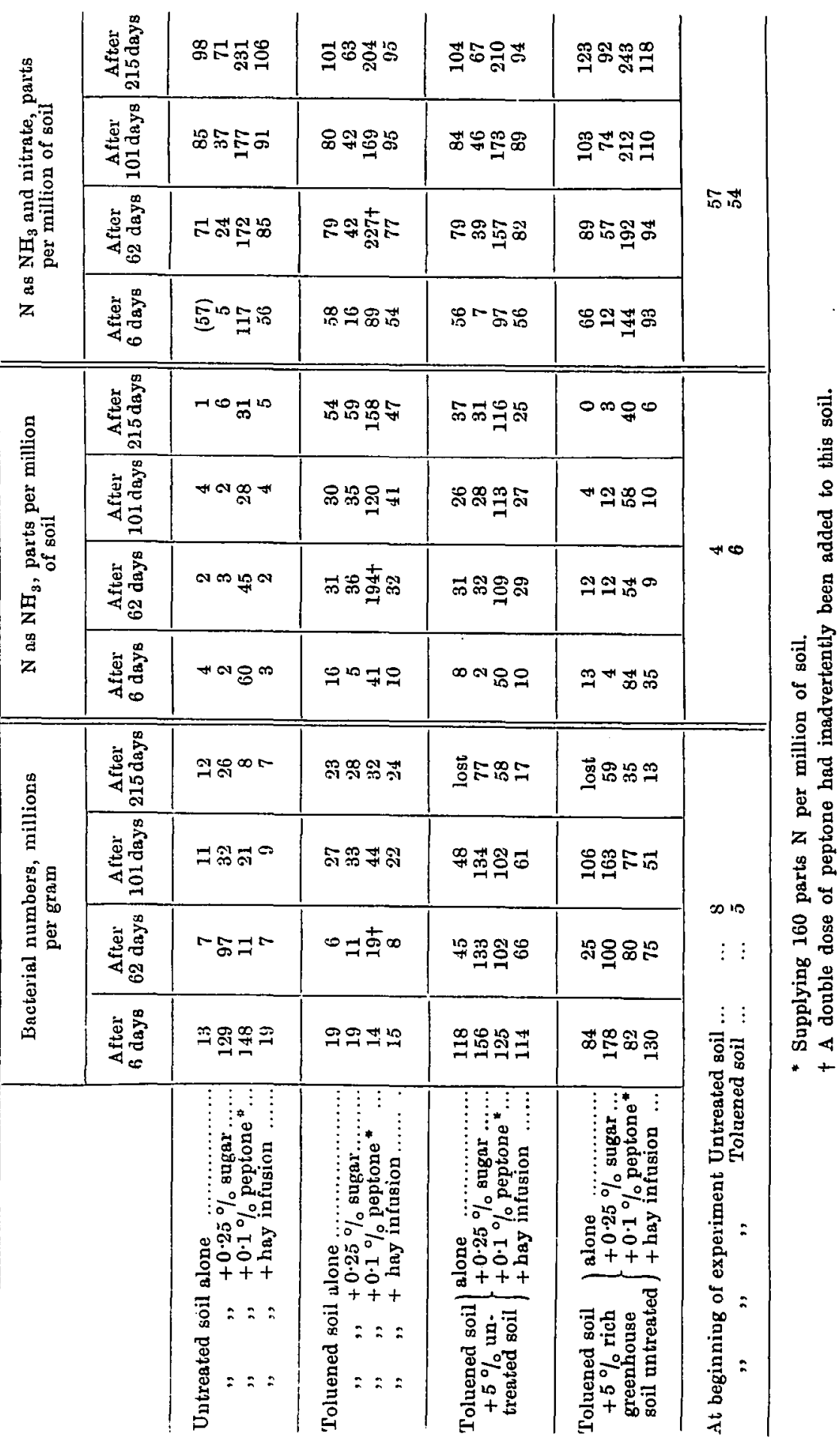




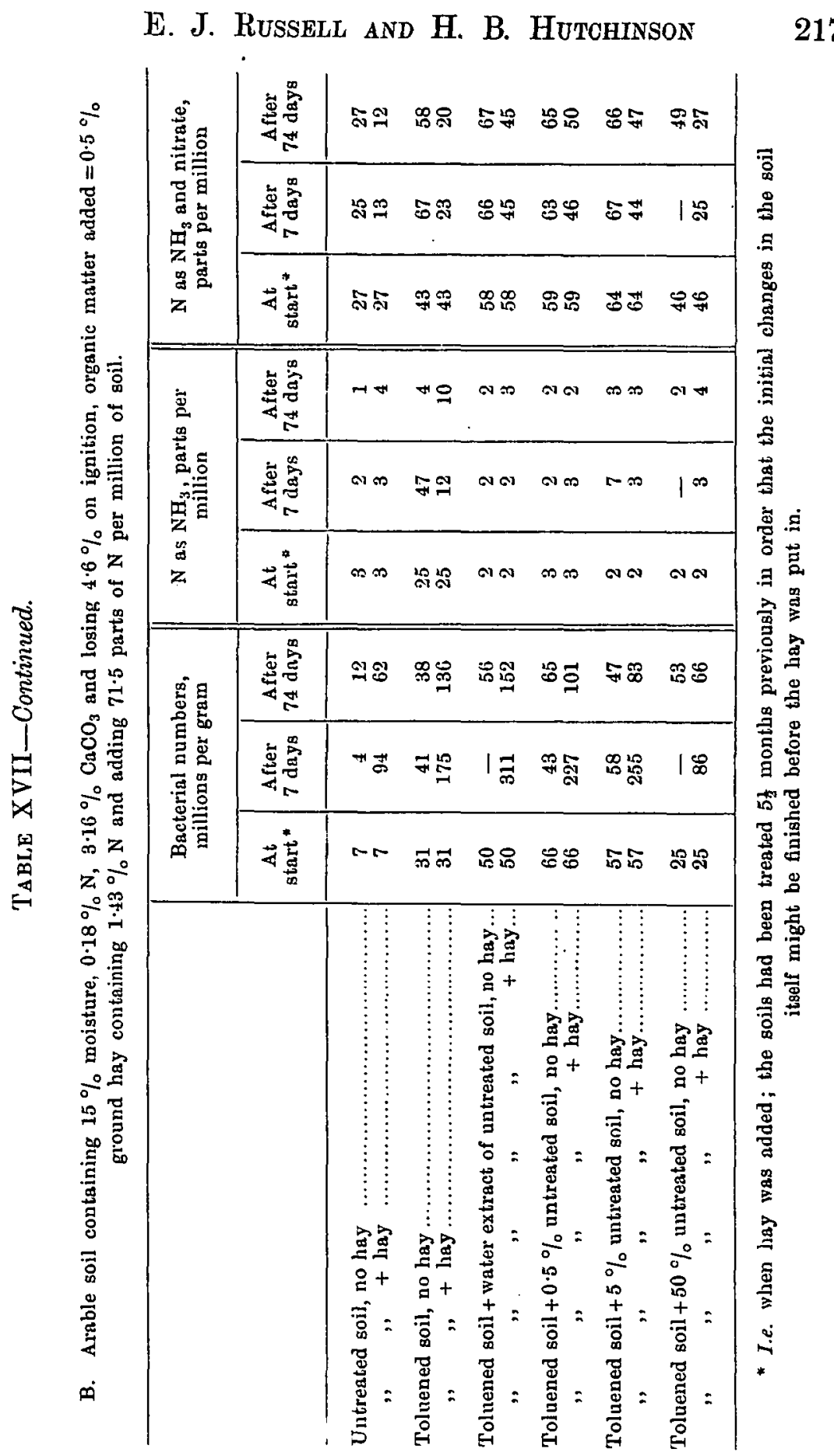




\section{Partial Sterilisation of Soil and Plant Food}

and partially sterilised soils were initially the same, the water content, temperature and aeration conditions are as nearly as possible identical; no attempt is made to compare one soil with another under different conditions. With these limitations the method gives valuable results and can continue to be used till a better is devised.

Other media are in use besides gelatine, but so far as they have been tried they give the same kind of results, indicating fluctuations in the same direction as gelatine although the actual figures are different.

$\S 60$. Perhaps the most striking proof of the validity of the gelatine plate method as we use it is that it leads to precisely the same conclusions as methods of a wholly different character. For example, the gelatine plate method shows that the numbers of bacteria increase after partial sterilisation. We have seen that special tests of an entirely different vature show an increase of denitrifying organisms and of organisms causing loss of nitrogen after partial sterilisation (footnote, p. 178); in our previous paper we showed that the rate of decomposition of peptone solution (in Remy's method) also increases. We have used these peptone solutions in testing some of the deductions drawn from the gelatine plate experiments, and have invariably found that both methods gave the same results. Two instances only need be given:

(1) From the gelatine plate counts we concluded that the effect of partial sterilisation was to improve the soil as a medium for bacterial growth and not to improve the bacteria as decomposition agents ( $\$ 24$ and 25). When small inoculations of soil are made into peptone solutions so that the effect shall be that of bacteria and not of soil, the partially sterilised soil is no better than the untreated. But when large inoculations are used, so that the effects of the detrimental organisms can come into play, the partially sterilised soil is distinctly better than the untreated. The amounts of ammonia in milligrams produced from a one per cent. peptone solution were:

\begin{tabular}{|c|c|c|c|c|}
\hline & & & & \\
\hline & After 24 & 32 & 44 & 80 \\
\hline $\begin{array}{l}\text { Small inoculation (effects of bacteria } \\
\text { only) }\end{array}$ & $\begin{array}{l}\text { Untreated soil..... } 0.5 \\
\text { Toluened soil } \ldots \ldots .0 .5\end{array}$ & $\begin{array}{l}7 \cdot 3 \\
7 \cdot 5\end{array}$ & $\begin{array}{l}8 \cdot 7 \\
8 \cdot 5\end{array}$ & $\begin{array}{l}21 \cdot 0 \\
20 \cdot 9\end{array}$ \\
\hline $\begin{array}{l}\text { Large inoculation (effects of bacteria) } \\
\text { and of detrimental organisms) }\end{array}$ & $\begin{array}{l}\text { Untreated soil...... } 4 \cdot 9 \\
\text { Toluened soil ..... } 6 \cdot 2\end{array}$ & $\begin{array}{l}15 \cdot 2 \\
18 \cdot 0\end{array}$ & $\begin{array}{l}21 \cdot 6 \\
23 \cdot 6\end{array}$ & \\
\hline
\end{tabular}

(2) From the gelatine plate experiments we concluded that the detrimental factor was not associated with the water extract but with 
the soil itself. A clear, fltered water extract of the untreated soil was found to be more effective in decomposing peptone than a similar extract of toluened soil, but a turbid extract was distinctly less effective. The amounts of ammonia in milligrams produced from one per cent. peptone were:

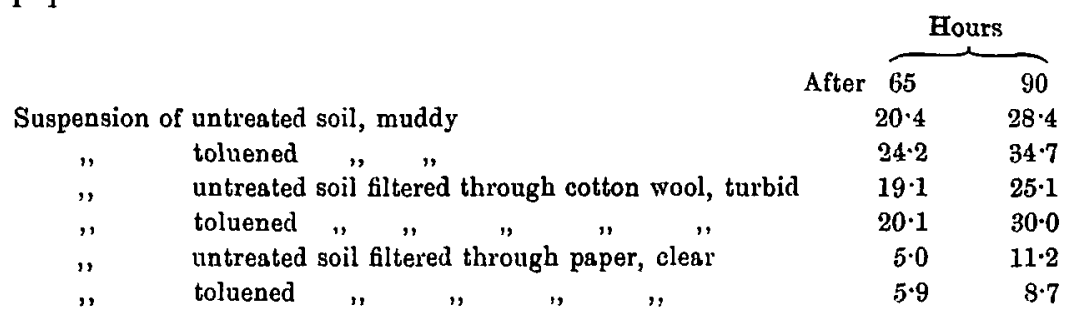

Thus in both cases the experiments lead to the same conclusion although the methods are fundamentally different. On the whole we prefer the gelatine plates to the culture solutions, but we use the culture solution methods to check the results yielded by the gelatine plates.

\section{Summary and Conclusions.}

The conclusions reached in our previous paper have been confirmed and extended. Fresh evidence is adduced that bacteria are not the only inhabitants of the soil, but that another group of organisms occurs, detrimental to bacteria, multiplying more slowly under soil couditions and possessing lower power of resistance to heat and to antiseptics.

In consequence of the presence of these detrimental organisms the number of bacteria present in the soil at any time is not a simple function of the temperature, moisture content and other conditions of the soil. It may, indeed, show no sort of connection with them; thus rise of temperature is found to be ineffective in increasing the bacteria in the soil; increase in moisture content has also proved without action. The number of bacteria depends on the difference in activity of the bacteria and the detrimental organisms.

But when soil has been partially sterilised the detrimental organisms are killed and the bacteria alone are left. It is then found that increase in temperature (up to a certain point) favours bacterial multiplication and causes the numbers to rise. Variations in moisture content also produce the normal results on partially sterilised, but not on untreated soils.

The detrimental organisms are killed by any antiseptic vapour or by heating the soil to $55^{\circ}-60^{\circ} \mathrm{C}$.: they suffer considerably when the 
soil is maintained at lower temperatures $\left(40^{\circ} \mathrm{C}\right.$.) for a sufficient length of time. Cooling to low temperatures also depresses them although it fails to kill them.

The completeness of the process can be accurately gauged by the extent to which the bacteria suffer. Whenever the treatment is sufficiently drastic to kill the nitrifying organisms and to reduce considerably the numbers of the other bacteria (as shown by the counts on gelatine plates) it also kills the detrimental organisms. If the soil conditions are now made normal, and the antiseptic is completely removed, rapid increase is observed in the bacterial numbers and the rate of production of ammonia. A temporary or partial suppression of the factor is, however, possible without extermination of the nitrifying organisms.

Once the detrimental organisms are killed the only way of introducing them again is to add some of the untreated soil. But the extent of the transmission is apt to be erratic, being sometimes more and sometimes less complete than at others; occasionally the infection fails altogether. We have not yet learned the precise conditions governing the transmission.

Provisionally we identify the detrimental organisms with the active protozoa of the soil, but as the zoological survey is yet incomplete we do not commit ourselves to any particular organism or set of organisms or to any rigid and exclusive definition of the term protozoa.

The increase in bacterial numbers following after partial sterilisation by volatile antiseptics is accompanied by an increase in the rate of ammonia production until a certain amount of ammonia or of ammonia and nitrate has accumulated, when the rate falls. Thus two cases arise: (1) when only small amounts of ammonia and nitrate are present there is a relationship between bacterial numbers and the rate of ammonia production, (2) when large amounts of ammonia or of ammonia and nitrate are present there is no relationship. The limit varies with the composition and condition of the soil.

Complications are introduced when the soil has been partially sterilised by heat, because heat effects an obvious decomposition of the organic matter, thus changing the soil as a medium for the growth of micro-organisms. The bacterial flora is also very considerably simplified through the extermination of some of the varieties. These effects become more and more pronounced as the temperature increases, and their tendency is to reduce the numbers of bacteria. We find maximum bacterial numbers in soils that have been heated to the minimum 
temperature necessary to kill the detrimental organisms (about $60^{\circ}$ ). Both bacterial numbers and the rate of decomposition in such soils approximate to those obtaining in soils treated with volatile antiseptics, and the above-mentioned relationships between these quantities also hold.

Although bacterial numbers are at a minimum in soils heated to $100^{\circ}$ the decomposition effected is at a maximum.

With this exception it is generally true that bacterial multiplication may go on without increasing the rate of production of ammonia, but an increase in the rate of production of ammonia does not take place without bacterial multiplication.

The increase in bacterial numbers brought about by addition of bacteria from the untreated soil into partially sterilised soil leads to still further production of ammonia and nitrate unless too large a quantity of these substances is already present. But the subsequent depression in bacterial numbers consequent on the development of the detrimental organisms is generally (though not always) without effect on the rate of decomposition, apparently because it does not set in until too late. 